UNIVERSIDADE DE SÃO PAULO

Faculdade de Arquitetura e Urbanismo

MARCELA MANTOVANI TEIXEIRA

\title{
Análise da sustentabilidade no mercado imobiliário residencial brasileiro
}

São Paulo

2010 


\section{MARCELA MANTOVANI TEIXEIRA}

\section{Análise da sustentabilidade no mercado imobiliário residencial brasileiro}

Dissertação apresentada à Faculdade de Arquitetura e Urbanismo da Universidade de São Paulo para obtenção do título de Mestre.

Área de concentração Projeto de Arquitetura

Orientador

Miguel Alves Pereira

São Paulo

2010 
Autorizo a reprodução e divulgação total ou parcial deste trabalho, por qualquer meio convencional ou eletrônico, para fins de estudo e pesquisa, desde que citada a fonte.

Mantovani, Marcela Teixeira

Análise da sustentabilidade no mercado imobiliário residencial brasileiro / Marcela Mantovani Teixeira; orientador Miguel Alves Pereira - São Paulo, 2010. $136 p$.

Dissertação (Mestrado) - Faculdade de Arquitetura e Urbanismo / Universidade de São Paulo, 2010.

1. Sustentabilidade 2. Arquitetura bioclimática 3. Mercado imobiliário 


\section{AGRADECIMENTOS}

Ao meu orientador, Miguel Alves Pereira, pela inspiração durante todo o período de pesquisa, pelos conselhos importantes para o norteamento do trabalho e por me ensinar a importância do engajamento político e profissional.

A Diana Csillag, pelo aconselhamento no início da pesquisa e pelas informações sobre certificação de edifícios.

A Paula Suda, moradora do Ecolife Butantã, pelas informações sobre o atendimento da empresa EcoEsfera às reclamações dos proprietários.

Aos meus familiares, pelo apoio e incentivo.

Aos meus amigos, pela compreensão nos momentos em que estive ausente.

Aos colegas arquitetos Renata e Eduardo, pela disposição e apoio na etapa final da pesquisa; e Fernanda, pela ajuda para conseguir o contato da empresa EcoEsfera.

A Rubén Roberto Velazco, amigo e chefe no momento de meu ingresso no mestrado, por me mostrar o caminho para o universo acadêmico.

A Helena Napoleon Degreas, pelas primeiras oportunidades na carreira acadêmica, pela confiança em meu trabalho.

A Carla Villano, pelo companheirismo nos momentos difíceis durante a pesquisa e pelo apoio, incentivo e amizade, acima de tudo.

A todos que, de alguma maneira, me ajudaram a realizar esta pesquisa. 


\section{RESUMO}

Com a virada do século XX para o século XXI, a devastação ambiental se tornou a principal ameaça a sobrevivência da humanidade no planeta. Descobrimentos alarmantes sobre o aumento do aquecimento global e a finitude dos recursos naturais trouxeram um novo desafio para o desenvolvimento mundial, crescer economicamente e ao mesmo tempo preservar o meio ambiente.

A atividade de construção, como parte das atividades que colaboram para o agravamento do problema ambiental, começa a ser repensada como forma de produção e esforços têm sido feitos para torná-la menos impactante ao meio ambiente e ao espaço urbano. Nesse contexto de incertezas que envolve o desenvolvimento sustentável, um conceito ainda recente para a maioria da população, diversas empresas procuram adaptar-se para produzir produtos ecologicamente corretos e ter atitudes ambientalmente responsáveis, porém, sem ter ainda conhecimento suficiente para propor soluções eficazes.

No mercado imobiliário brasileiro, tem crescido o volume de empreendimentos que são lançados como "empreendimentos sustentáveis", considerados mais eficientes no consumo de recursos naturais e menos agressivos para o meio ambiente, ao passo que cresce, também, o interesse da população pelo consumo desse tipo de produto. Mostra-se, portanto, necessário fazer uma avaliação da real eficiência desses edifícios, pois, a observação da maneira impactante como esses empreendimentos se inserem no espaço urbano e sua baixa qualidade arquitetônica, indicam que há uma distorção do conceito de sustentabilidade no mercado.

Este estudo pretende contribuir para o melhor entendimento do termo "sustentabilidade" e alertar para a maneira incorreta como ele tem sido, atualmente, inserido na produção do mercado imobiliário de edifícios residenciais, no Brasil. 


\begin{abstract}
With the turn of the century $X X$ to the $X X I$, environmental devastation became the main threat to survival of humanity on the planet. Discoveries about the alarming increase in global warming and finite natural resources have brought anew challenge to world development: to promote economic growth while preserving the environment.
\end{abstract}

Construction activity, as part of activities that contribute to the worsening environmental problem begins to be reconsidered as a means of production and efforts have been made to make it less harmful to the environment and urban space. In this context of uncertainty surrounding the sustainable development, a relatively new concept to most people, several companies trying to adapt to produce environmentally friendly products and be environmentally responsible, but without yet having enough knowledge to propose effective solutions.

The brazilian real estate market has grown the volume of projects that are launched as "sustainable business" as more efficient consumption of natural resources and less harmful to the environment, while growing, too, public interest in the consumption these products. It is apparent, therefore, necessary to evaluate the real efficacy of these buildings, therefore, the observation of the way significant as these developments fall within the urban space and its low architectural quality, indicate that there is a distortion of the concept of sustainability in the market.

This study aims to contribute to a better understanding of the term "sustainability" and alert to incorrectly as it has been currently inserted in the production of the property market of residential buildings in Brazil. 


\section{LISTA DE TABELAS}

Tabela 2.1. Evolução das prioridades ambientais 23

Tabela 2.2. Recursos consumidos na atividade de construção 32

$\begin{array}{ll}\text { Tabela 2.3. Os quatros erres } & 39\end{array}$

Tabela 3.1. Redução de déficit habitacional por Estado, em um ano de PlanHab 57

Tabela 3.2. Estrutura de avaliação do LEED for Homes 67

Tabela 3.3. Estrutura de avaliação do BREEAM Multi-Residential 68

Tabela 3.4. Sistemas de avaliação que compõem o CASBEE 69

Tabela 3.5. Estrutura de avaliação do CASBEE 70

Tabela 3.6. Organização dos domínios HQE em metas 72

Tabela 3.7. Fases do ciclo de vida de um edifício abordadas por sistema 73

Tabela 3.8. Agrupamento das categorias do sistema AQUA Habitacional 75

Tabela 4.1. Comparação entre os itens de sustentabilidade do Ecolife

Independência e os requisitos do processo AQUA de certificação 85

Tabela 4.2. Comparação entre os itens de sustentabilidade dos

empreendimentos e os requisitos do processo AQUA de certificação 106 


\section{LISTA DE GRÁFICOS}

Gráfico 2.1. Quanto cada setor contribui para o efeito estufa 31

Gráfico 2.2. Gastos com construção por país no ano de 2004

Gráfico 2.3. Crescimento dos gastos com construção por país (2004-2005) 34

Gráfico 2.4. Possibilidade de interferência no custo total de um edifício 38

Gráfico 3.1. Déficit habitacional por faixa de renda 55

Gráfico 3.2. Déficit habitacional acumulado por faixa de renda 55

Gráfico 3.3. Evolução do déficit habitacional absoluto (2005-2007) 56

Gráfico 3.4. Índice de Desenvolvimento Habitacional brasileiro 58

Gráfico 3.5. Lançamento de unidades habitacionais em São Paulo nos últimos $\begin{array}{ll}10 \text { anos } & 59\end{array}$

Gráfico 3.6. Trabalhadores com carteira no setor de construção (2004-2008) 60

Gráfico 3.7. Renda média na construção (2005-2007) 60

Gráfico 4.1. Atendimento às Categorias do processo AQUA pelo Ecolife

Independência 90

Gráfico 4.2. Atendimento às Categorias do processo AQUA pelos

$\begin{array}{ll}\text { empreendimentos } & 107\end{array}$

Gráfico 4.3. Atendimento aos requisitos do processo AQUA por

$\begin{array}{ll}\text { empreendimento } & 108\end{array}$ 


\section{LISTA DE FIGURAS}

Figura 2.1. Tripé da sustentabilidade $\quad 25$

Figura 3.1. Edifício Lausanne 44

Figura 3.2. Edifício Lugano / Locarno 45

Figura 3.3. Edifício Bretagne $\quad 45$

Figura 3.4. Edifício Prudencia 46

Figura 3.5. Edifício Cinderela 46

$\begin{array}{ll}\text { Figura 3.6. Edifício Louveira } & 47\end{array}$

Figura 3.7. Edifício Três Marias $\quad 47$

Figura 3.8. Edifício Conjunto Nacional 48

$\begin{array}{ll}\text { Figura 3.9. Edifício Nações Unidas } & 48\end{array}$

Figura 3.10. Edifício Paulicéia 49

Figura 3.11. Sistemas de certificação existentes no mundo 64

Figura 4.1. Implantação do Ecolife Independência 79

Figura 4.2. Fachada do Ecolife Independência 81

Figura 4.3. Planta da Unidade 3 do Ecolife Independência 82

Figura 4.4. Planta da Unidade 3 do Ecolife Independência com opção de dois dormitórios 82

Figura 4.5. Planta da Unidade 1 do Ecolife Independência 83

Figura 4.6. Fachada do empreendimento Plaza Mayor Alto da Lapa 94

Figura 4.7. Fachada do empreendimento Príncipe de Greenfield 95

Figura 4.8. Fachada do empreendimento Latitude $23^{\circ}$

Figura 4.9. Fachada do empreendimento Mundo Apto Alto da Lapa 97

Figura 4.10. Fachada do empreendimento Absolutto Condomínio Clube 97

Figura 4.11. Fachada do empreendimento Evolution Ecologic Residencial 98

Figura 4.12. Fachada do empreendimento Green Life Residence 99

Figura 4.13. Fachada do empreendimento Green Life Residence $2 \quad 100$

Figura 4.14. Fachada do empreendimento Residencial Exclusive Euroville $\quad 100$ 
Figura 4.15. Fachada do empreendimento Felicita Eco Residencial

Figura 4.16. Fachada do empreendimento Esmeralda Residence 102

Figura 4.17.Fachada do empreendimento Residencial Eco Parque 103

Figura 4.18. Fachada do empreendimento MORE Alphaville 104

Figura 4.19. Fachada do empreendimento Bella Vita Eco Club 105

Figura 4.20. Ocorrência de greenwash - website da empresa EcoEsfera 120

Figura 4.20. Ocorrência de greenwash - website da empresa EcoEsfera 121

Figura 4.22. Ocorrência de greenwash - website do empreendimento Ecolife $\begin{array}{ll}\text { Independência } & 121\end{array}$

Figura 4.23. Ocorrência de greenwash - website da empresa Euroamérica 122

Figura 4.24. Ocorrência de greenwash - website do empreendimento Euroville 122

Figura 4.25. Ocorrência de greenwash - website do empreendimento Absolutto 123

Figura 4.26. Ocorrência de greenwash - website da empresa MRV 123 


\section{SUMÁRIO}

Agradecimentos

Resumo

Abstract

Lista de Tabelas

Lista de Gráficos

Lista de Figuras

\section{Introdução}

1.1 Objetivo

1.2 Justificativa

1.3 Metodologia

18

1.4 Estrutura da Dissertação

\section{Desenvolvimento Sustentável}

2.10 surgimento da sustentabilidade

2.2 Desenvolvimento e progresso

2.3 Impactos ambientais da atividade de construção

\section{Mercado Imobiliário e Sustentabilidade}

3.1 A sustentabilidade na produção das décadas de 50, 60 e 70

3.20 mercado imobiliário brasileiro após a virada do século (XX-XXI)

$3.3 \mathrm{O}$ uso das certificações ambientais

4.1 Análise do empreendimento Ecolife Independência

4.2 Análise dos empreendimentos selecionados 
1. INTRODUÇÃO 


\subsection{Objetivo}

Embora tenha havido, recentemente, um aumento do interesse sobre o assunto abordado neste trabalho, um primeiro levantamento revelou que, no meio acadêmico, o estudo sobre a Sustentabilidade na Arquitetura, e, especificamente, o estudo da Sustentabilidade no Mercado Imobiliário é, ainda, pouco aprofundado, levando-se em conta a importância do tema. Com o intuito de explorar o assunto, este trabalho pretende contribuir tanto oferecendo um conhecimento novo, quanto estimulando outros pesquisadores a estudar o tema.

O objetivo deste trabalho é estudar o processo de inserção do conceito de sustentabilidade no mercado imobiliário de habitação e sua real contribuição para a minimização dos impactos ambientais causados pela atividade de construção. Para tanto, faremos uma análise quantitativa dos itens de sustentabilidade incorporados por quatorze empreendimentos residenciais, cujos lançamentos foram promovidos tendo como enfoque a sustentabilidade. Analisaremos também, de maneira mais aprofundada, um empreendimento residencial de médio padrão da empresa Ecoesfera Empreendimentos Sustentáveis, cujo projeto recebeu a pré-certificação LEED de construção sustentável. 


\subsection{Justificativa}

As últimas décadas foram de estagnação para o mercado imobiliário brasileiro. O insignificante crescimento econômico das décadas de 1980 e 1990 impediu o desenvolvimento do setor de construção e do mercado imobiliário no Brasil. Durante esse período, outros países em desenvolvimento estiveram na mesma condição, enquanto nos países desenvolvidos a trajetória do setor apontava para uma nova preocupação: a diminuição dos impactos ambientais da construção de edifícios. Essa preocupação com a preservação do meio ambiente, que hoje tem sido discutida amplamente e a qual tem-se tentado adotar em todas as atividades, encontrou no setor de construção um de seus potenciais aliados. A atividade de construção é a atividade que mais causa impactos negativos ao meio ambiente no mundo. Entre esses impactos, os principais são: aumento do lixo urbano, enchentes, desmoronamentos, poluição dos recursos hídricos, poluição do ar, impermeabilização da superfície do solo, desmatamentos, congestionamento dos transportes e emissão de gases que contribuem para o efeito estufa. A adequação da atividade para um quadro menos impactante pode colaborar significativamente para a minimização do aquecimento global.

Com a chegada do século XXI, o dever de aliar o aumento do volume de construções à diminuição dos impactos ambientais da atividade de construção levou grande parte das empresas do setor imobiliário a adotar estratégias para tornar os empreendimentos mais "sustentáveis". A população, por sua vez, mostra o desejo de se engajar e contribuir para a causa ambiental, procurando, quando possível, consumir produtos ecologicamente corretos, e isso ocorre em todos os setores de atividade, inclusive no mercado imobiliário.

Em princípio, essa relação entre compra e venda de produtos ecológicos se mostra positiva, já que o aumento da demanda leva à necessidade do surgimento de um novo modo de produção, menos agressivo ao meio ambiente. No entanto, a procura por produtos ecológicos levou o mercado a direcionar seu enfoque para a 
venda desses produtos e a usar o marketing sustentável para atrair os consumidores. O problema desse direcionamento, porém, é que uma relevante parcela dessa produção - e talvez a mais forte - esteja relacionada [apenas] ao interesse mercadológico e publicitário dos "eco-produtos", [e não à sua real contribuição ambiental], e a arquitetura tem sido inserida como mais uma linha de produtos na prateleira (SOBREIRA, 2009).

Com isso, uma nova geração de edifícios, caracterizados por premissas ambientais e marcados por um alto grau de experimentação, complexidade e risco, tem sido construída nas grandes cidades do mundo (GONÇALVES, 2005). No Brasil, essa tendência tem se tornado cada vez mais forte, principalmente na construção de edifícios comerciais e empreendimentos residenciais, sempre tomando como base os padrões de sustentabilidade já adotados internacionalmente, através de certificações elaboradas pelos países que já possuem uma experiência nesse tipo de construção. A certificação internacional, porém, não garante o bom desempenho ambiental de um edifício construído no Brasil. A avaliação realizada por meio de uma pontuação, através da aplicação de aspectos padronizados de projeto, não é suficiente para medir a eficiência no uso dos recursos naturais por um edifício. No entanto, a necessidade mercadológica de uma "comprovação de sustentabilidade" levou as empresas a utilizarem essas certificações ou selos "verdes" na divulgação de seus produtos. Percebemos, atualmente, que no mercado imobiliário brasileiro a obtenção de selos tem se tornado uma meta projetual, e como conseqüência, o projeto tem sido conduzido segundo roteiros pré-estabelecidos e globais de "cartilhas ambientais", independente de sua pertinência e contextualização local (SOBREIRA, 2009).

A gravidade dessa situação está na idéia de contribuição ambiental por parte das empresas, ao oferecerem bens e produtos que acreditam ajudar a preservar 0 meio ambiente, e dos consumidores, ao adquirirem esses bens e produtos, sem realmente estarem contribuindo com a causa ambiental. Essa desinformação disseminada por uma organização ou empresa, de modo a apresentar uma imagem pública ambientalmente responsável, mas percebida como sendo infundada ou 
enganosa (Oxford English Dictionary, 2009) é chamada de greenwash. No Brasil, a palavra verniz verde passou a ser utilizada com o mesmo sentido.

Com o recente crescimento da discussão sobre o futuro do planeta, e com incontestável influência da ação humana sobre o meio ambiente, fica evidente a necessidade de participação da população para minimizar os transtornos ambientais causados pelo homem. A maneira mais simples de participar, dentro da lógica econômica que rege o mundo atual, é consumindo produtos e serviços que tenham um processo de produção com baixo impacto ambiental. Uma pesquisa recente, realizada pela empresa Futerra Sustainability Communications, indica que os consumidores têm procurado por produtos com atributos "ecológicos" e a tendência é de que cada vez mais pessoas se interessem por este tipo de produto.

Acompanhando essa tendência, as empresas de construção têm investido no marketing ecológico como forma de divulgar os seus produtos, que tenham um ou mais aspectos que colaborem para a preservação ambiental. Mas, mais por falta de conhecimento do que pela intenção de enganar, muitas empresas não cumprem as promessas de benefícios ambientais, salientados em sua publicidade, e acabam cometendo enganos que induzem o consumidor ao erro no momento da compra. No mercado imobiliário, a pressa para não perder a crescente demanda por edifícios mais eficientes, tem levado as empresas a lançarem empreendimentos que usam palavras como "sustentável" ou "ecológico" para atrair os consumidores, que mostram cada vez mais o interesse por este tipo de imóvel.

Cabe aos profissionais ligados à área de construção, fazer uso de seu conhecimento para aprimorar o processo de renovação da atividade de construção e contribuir para que ele seja legítimo. Deve haver uma mudança no processo de construção para que a atividade diminua os impactos causados ao meio ambiente e os arquitetos tem papel fundamental dentro deste processo, elaborando projetos mais conscientes e adequados à realidade brasileira. 


\subsection{Metodologia}

A metodologia adotada para a pesquisa consistiu, em primeiro lugar à consulta sobre o tema "Sustentabilidade" e sua inserção na atividade de construção. Procuramos identificar, através de consulta a estudos já realizados, as estratégias que devem ser incorporadas ao processo de projeto para a realização de construções que causem menos impactos ao meio ambiente.

Após a identificação dessas estratégias, realizamos um estudo sobre os aspectos de sustentabilidade adotados pelo empreendimento Ecolife Independência, da incorporadora e construtora EcoEsfera Empreendimentos Sustentáveis, précertificado pelo sistema LEED - Leadership in Energy and Environmental Design. Nesse estudo foram feitas análises de implantação, fachadas, plantas das unidades. Foi feita, também, uma comparação entre os itens de sustentabilidade do empreendimento e os requisitos do processo AQUA de certificação.

Em um segundo estudo fizemos um levantamento dos empreendimentos imobiliários residenciais, em cujos lançamentos se utilizou o conceito de sustentabilidade. Procuramos escolher, para a amostra, edifícios de diferentes empresas, localidades e padrões, de modo que fosse possível ter uma visão mais abrangente das ações de sustentabilidade adotadas pelas empresas do setor de construção no Brasil. Os dados sobre as ações de sustentabilidade das empresas escolhidas foram comparados aos requisitos do processo AQUA de certificação, o único sistema de certificação adaptado à realidade brasileira, permitindo a verificação do nível de comprometimento dessas empresas com a preservação ambiental, com o espaço urbano e com aspectos sociais. 


\subsection{Estrutura da Dissertação}

A estrutura deste trabalho está organizada em seis capítulos, conforme apresentado abaixo:

No Capítulo 1 são descritos o objetivo, justificativa e metodologia adotada para realização da pesquisa.

O Capítulo 2 introduz o tema da "Sustentabilidade", com esclarecimentos sobre seu surgimento, suas implicações no contexto atual de esenvolvimento e sua relação com a atividade de construção. São trabalhados, também, os conceitos de "Progresso" e "Desenvolvimento", como forma de embasamento para o melhor entendimento das considerações da autora, na etapa final do trabalho.

No Capítulo 3 serão abordados aspectos da qualidade na produção imobiliária residencial das décadas de 1950, 1960 e 1970, cujos projetos são considerados, ainda hoje, referência de boa arquitetura para a produção imobiliária residencial. Neste trabalho, esses projetos são, também, referência de sustentabilidade tanto no uso dos recursos naturais, como na implantação do edifício no terreno e no comprometimento com o espaço urbano, fechando o triângulo virtuoso (Triple Botton Line), o qual abrange os três aspectos pré-estabelecidos para o alcance da sustentabilidade: justiça social, preservação ambiental e desenvolvimento econômico. Falaremos, também, sobre o desenvolvimento do setor imobiliário na última década e sua adaptação aos conceitos de sustentabilidade, com o surgimento das certificações internacionais para avaliação de edifícios.

O capítulo 4 descreve os estudos realizados com os empreendimentos escolhidos para análise, através da comparação entre as ações de sustentabilidade adotadas pelo mercado e os requisitos do processo AQUA de certificação. Serão feitas considerações sobre o comprometimento das empresas com a preservação ambiental e aspectos sociais. 
No Capítulo 5 serão feitas as considerações finais sobre a inserção dos conceitos de sustentabilidade em empreendimentos imobiliários residenciais, e sua real contribuição para diminuição dos impactos ambientais das construções.

O Capítulo 6 apresenta as referências bibliográficas e eletrônicas consultadas para realização da pesquisa. 
2. DESENVOLVIMENTO SUSTENTÁVEL 


\subsection{O Surgimento da Sustentabilidade}

Os impactos ambientais das atividades humanas sobre o planeta são, hoje, conhecidamente, uma ameaça ao futuro da nossa espécie. Nos últimos anos, o assunto deixou de ser restrito aos meios científico e acadêmico e passou a fazer parte dos discursos políticos e empresariais. A constatação de que já estamos vivendo as conseqüências de um modelo de desenvolvimento exploratório e de que haverá efeitos mais graves futuramente, despertou a humanidade para a ameaça do aquecimento global. A publicação do quarto Relatório do Intergovernmental Panel on Climate Change (IPCC, 2007), apresentado em maio de 2007, em Bangkoc, Tailândia, confirma as alterações provocadas no clima por meio das atividades humanas e propõe mudanças para evitar ou diminuir a ocorrência de catástrofes ambientais nas próximas décadas.

Nos últimos dois séculos, presenciamos o desenvolvimento da máquina, o crescimento da população mundial, o surgimento do consumo em massa, a evolução das tecnologias e a melhora das condições de vida. Também, durante esse período, exploraram-se de forma ilimitada os recursos naturais disponíveis na natureza, em prol do desenvolvimento econômico mundial. Somente nos últimos cinqüenta anos, a preocupação com a preservação do meio ambiente passou a ser discutida e começou a ser considerada a idéia de que o modelo de desenvolvimento existente até então, baseado em uma exploração excessiva dos recursos naturais, seria incapaz de garantir a sobrevivência da espécie humana no futuro. Ao longo do tempo, percebeu-se que a visão de progresso (que se confundia com o domínio e a transformação da natureza, cujos recursos naturais eram vistos como ilimitados) e a preservação ambiental (que se limitava à criação de parques e áreas especiais destinadas à preservação de amostras da natureza para evitar a extinção de espécies) passaram a ser insuficientes (FOSSATI, 2008). 
Após a Segunda Guerra Mundial, o avanço do conhecimento sobre poluentes orgânicos, a destruição da camada de ozônio e o efeito estufa decorrentes de gases produzidos e liberados pelo homem, demonstrou que a preservação da natureza exigia uma reformulação mais ampla dos processos produtivos e de consumo. Isso implicou em uma reformulação da visão do impacto ambiental das atividades humanas, passando também a incorporar todos os impactos das atividades de produção e de consumo - desde a extração da matéria-prima, os processos industriais, o transporte e o destino dos resíduos de produção e do produto após sua utilização (JOHN, 2001).

A partir da década de 70, houve um aumento da preocupação com a degradação ambiental. A crise do petróleo alertou para os problemas causados pelo modelo de desenvolvimento adotado, que seguia um ritmo acelerado de produção. Acelerava-se, também, o crescimento da população mundial e da população residente em áreas urbanas, alertando para o esgotamento dos recursos naturais e deterioração ambiental do planeta. Reuniões mundiais começaram a ser realizadas, com o intuito de encontrar soluções que permitissem um desenvolvimento menos impactante para as cidades. Entre essas reuniões, destacam-se a Conferência das Nações Unidas sobre o Ambiente Humano (Estocolmo, 1972), a Convenção de Viena para Proteção da Camada de Ozônio (Viena, 1985), o Protocolo de Montreal (Montreal, 1987), a Conferência das Nações Unidas sobre Ambiente e Desenvolvimento - ECO92 (Rio de Janeiro, 1992), a Conferência das Nações Unidas (Istambul, 1996), o Protocolo de Quioto (1997), a Cúpula Mundial sobre Desenvolvimento Sustentável - Rio+10 (Joanesburgo, 2002), e o mais recente encontro entre líderes mundiais para discussão sobre desenvolvimento e mudanças climáticas, a Conferência das Nações Unidas sobre Mudanças Climáticas COP15 (Copenhagen, 2009).

O termo "desenvolvimento sustentável" surgiu em 1987, com a publicação do relatório Nosso Futuro Comum, elaborado pela Comissão Brundtland, a partir de estudos sobre o modelo de desenvolvimento dos países industrializados e a capacidade de mantenimento dos recursos naturais. No relatório, ele é definido como aquele "que satisfaz as necessidades das gerações atuais, sem comprometer a 
capacidade das gerações futuras de satisfazer suas próprias necessidades" (BRUNDTLAND, 1987). Alguns anos depois, a Agenda 21, documento elaborado durante a Eco-92, reafirma a importância da preservação dos recursos naturais para a sobrevivência das próximas gerações e estabelece que cada país deve se comprometer local e globalmente, com a criação de sua própria Agenda 21, com ações que ajudem a sociedade a seguir um novo rumo, reintepretando o conceito de progresso, contemplando maior harmonia e equilíbrio entre o todo e as partes, promovendo a qualidade e não apenas o crescimento.

No decorrer dos últimos 40 anos, conforme evoluiu a discussão sobre a preservação ambiental, definiram-se prioridades ambientais de acordo com as necessidades de cada período, conforme mostra a Tabela 2.1. Passada a crise de energia da década de 1970, a questão energética deixou de ser prioridade e se tornou parte do problema, que agora envolve outras questões como saúde, estresse e produtividade. O conceito de sustentabilidade passou a situar o ser humano dentro do sistema natural, ao invés de separá-lo da questão ambiental, como se fazia quando a ênfase estava centrada na energia (EDWARDS, 2004).

\begin{tabular}{|c|c|}
\hline Década de 1970 & Escassez de energia \\
\hline \multirow[t]{3}{*}{ Década de 1980} & Aquecimento global \\
\hline & Conceito de Desenvolvimento Sustentável \\
\hline & Destruição da camada de ozônio \\
\hline \multirow[t]{3}{*}{ Década de 1990} & Distribuição e qualidade dos recursos hídricos \\
\hline & Proteção das florestas tropicais \\
\hline & Biodiversidade \\
\hline \multirow[t]{3}{*}{ Década de 2000} & Saúde das cidades \\
\hline & Desenvolvimento e construção sustentáveis \\
\hline & Sustentabilidade e saúde do ser humano \\
\hline
\end{tabular}

Fonte: Edwards, 2004

Com a virada do século $X X$ para o século $X X I$, o termo começou a ser popularizado, e a idéia de sustentabilidade começou a ser incorporada à sociedade. As empresas passaram a adotar o discurso ecológico para promover seus produtos; uma 
parcela da sociedade, considerada mais engajada na causa ambiental, passou a consumir esses produtos; políticos passaram a incluir ações de preservação ecológica em seus planos de governo; e até mesmo algumas escolas reelaboraram seus programas de ensino para incluir disciplinas sobre preservação do meio ambiente. Palavras que antes eram utilizadas apenas nos discursos dos ambientalistas, como: "ecológico", "ambiental" e "sustentável" agora são encontradas em grande parte dos produtos consumidos todos os dias pela população, desde produtos alimentícios, produtos de limpeza, itens de papelaria, roupas, calçados, materiais de construção, até automóveis e edifícios.

No grupo das atividades que colaboram para o agravamento do aquecimento global, a atividade de construção é apontada como uma das mais impactantes, tendo em vista que os materiais e métodos necessários para a realização das construções consomem a maior parte dos recursos naturais extraídos da natureza. Entre eles água, madeira e minérios extraídos do solo.

No que diz respeito à indústria da construção, o entendimento ou interpretação da sustentabilidade tem passado por mudanças ao longo dos anos. Inicialmente, a ênfase estava em como lidar com recursos limitados - especialmente energia - e como reduzir os impactos sobre o meio ambiente. $O$ enfoque estava baseado em requisitos mais técnicos da construção como materiais, componentes do edifício, tecnologias construtivas e conceitos de projetos relacionados à energia (FOSSATI, 2008). Ainda hoje, a sustentabilidade, na maior parte das construções, limita-se ao emprego de materiais e componentes com eficiência ecológica. Entretanto, recentemente, as questões sociais e econômicas, os aspectos culturais e de patrimônio construído passaram a ser considerados essenciais para a realização da construção sustentável, atendendo ao tripé da sustentabilidade, um conceito criado pelo Relatório Brundtland, em 1987 e utilizado atualmente como base para medir a responsabilidade ambiental de empresas. Nesse triângulo, a sustentabilidade se constitui pela relação entre proteção ambiental, justiça social e crescimento econômico, tornando possível o desenvolvimento sustentável (Figura 2.1). 

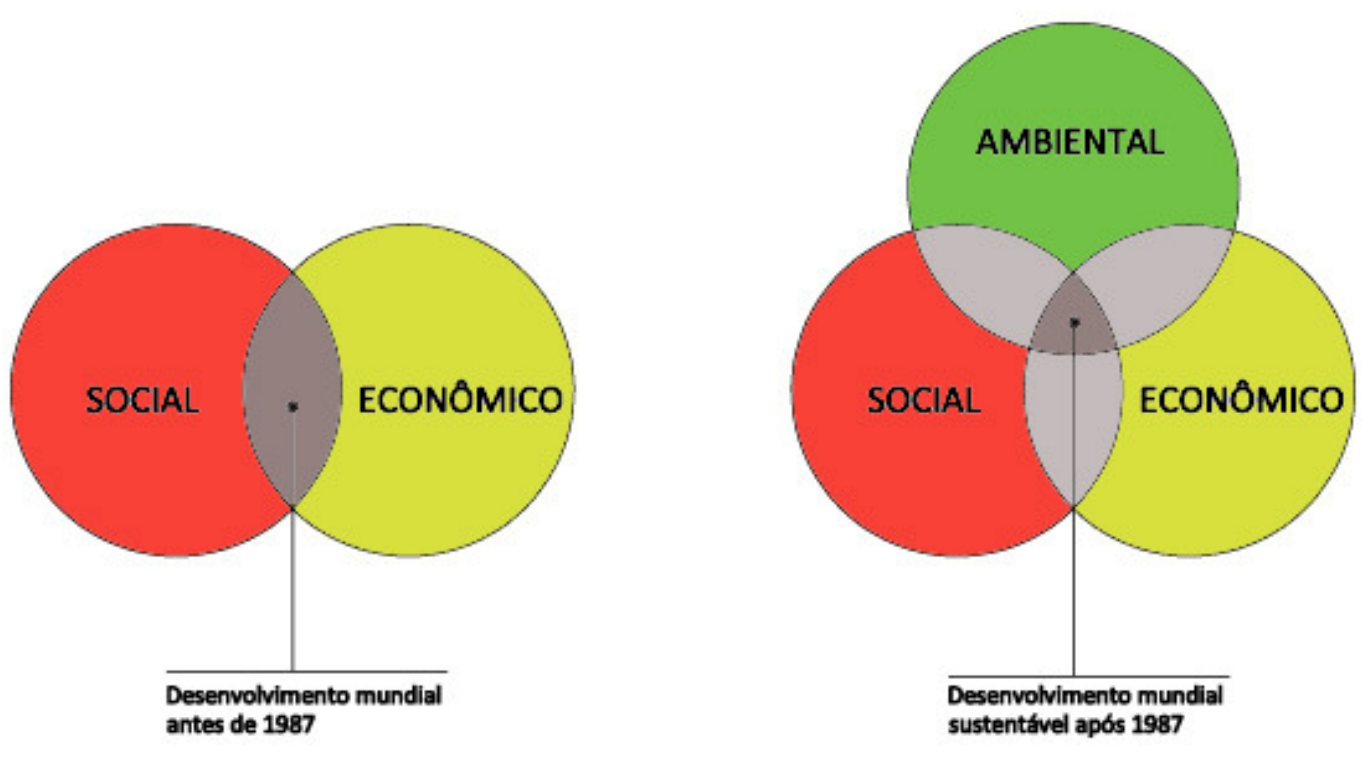

O desenvolvimento mundial sustentável ainda está longe de ser alcançado. A teoria do tripé da sustentabilidade esbarra em uma forte resistência econômica, que na maioria das vezes tem maior peso nas tomadas de decisão. Resulta deste fato a existência de um alto índice de subnutrição (1,1 bilhão de habitantes) e miséria (2,8 bilhões de habitantes) no mundo (KRONKA, 2006), e a devastação ambiental do planeta.

A evolução do debate sobre os problemas ambientais representa um importante passo para a conscientização da população, desde que não seja norteado por interesses que fujam do objetivo coletivo, que é a preservação da natureza. Infelizmente, durante as últimas reuniões realizadas entre os países desenvolvidos e os países em processo de desenvolvimento, as decisões de metas levaram mais em conta as exigências econômicas do que os interesses ambientais. Conforme descrito por Meadows em Limits to Growth, 2004, inúmeras reuniões têm sido realizadas com a intenção de encontrar meios para a minimização da degradação ambiental; no entanto, todas elas têm sido pouco eficientes, com debates bem intencionados, porém, afetados pela disputa de interesses (MEADOWS, 2004: p. xvi). Exemplo disso 
ocorreu durante o encontro de líderes mundiais para assinatura do Protocolo de Quioto (1997), documento que define metas para redução de emissão de CO2 pelos países mais poluentes do mundo. Os países que têm os maiores índices de emissão de gás carbônico na atmosfera, Estados Unidos e China, se recusaram a cumprir o compromisso de diminuir suas emissões, com a justificativa de que isto prejudicaria seu processo de desenvolvimento.

Conforme afirmam os pesquisadores do IPCC - Intergovernmental Panel on Climate Change, se as emissões não forem reduzidas e o ritmo de crescimento mundial não for freado, poderemos ter, a partir do ano 2050, temperaturas mais altas, pouca reserva de água e combustíveis fósseis, e um nível de poluição extremamente prejudicial à saúde humana. 


\subsection{Desenvolvimento e Progresso}

A idéia de progresso está relacionada ao avanço, à evolução de um estado para outro superior. No dicionário Houaiss da Língua Portuguesa, "progresso" é definido como:

1. Ação ou resultado de progredir, progressão, progredimento;

2. Movimento para diante; avanço;

3. O fato de se expandir, propagar-se; propagação, expansão;

4. Mudança de estado (de algo) que o move para um patamar superior; crescimento, desenvolvimento, aumento;

5. Mudança considerada desejável, ou favorável; avanço, melhoria, desenvolvimento;

6. Incorporação, no dia-a-dia das pessoas, das novas conquistas no campo tecnológico, da saúde, da construção, dos transportes, etc;

7. Processo de enriquecimento de uma cidade, de uma região, de um país, etc. com a instalação de indústrias e casas comerciais, transporte urbano, estradas, meios de comunicação, etc.; desenvolvimento.

No Dicionário Online da Língua Portuguesa Priberam, a palavra "progresso" é definida como:

1. Marcha ou movimento para adiante;

2. Adiantamento;

3. Desenvolvimento;

4. Movimento progressivo da civilização;

5. Aperfeiçoamento.

A palavra desenvolvimento está fortemente relacionada com a idéia de progresso e muitas vezes se confunde com o termo, como se fossem sinônimos. Procurando, nas mesmas fontes, pelo termo "desenvolvimento", encontramos as definições: 
1. Ato ou efeito de se desenvolver;

2. Aumento, progresso;

3. Ampliação;

4. Explanação;

5. Minuciosidade;

6. Incremento;

7. Propagação.

A idéia de progresso surgiu ainda na Grécia Antiga, quando filósofos tiveram a primeira percepção de avanço ao longo do tempo. No decorrer da história ela esteve associada a conquistas tecnológicas, como o descobrimento do fogo, o uso de metais, o desenvolvimento da linguagem, da navegação, das artes, da família e da ordem social. Decaiu na Idade Média, quando o pensamento cristão definia que o grande movimento da história visava assegurar a felicidade de uma pequena parcela da raça humana em um outro mundo: daqueles que aceitassem e cumprissem as determinações da revelação divina, não havendo interesse em melhoramentos graduais da sociedade. A idéia de progresso retornou pouco a pouco na etapa final do Renascimento, na segunda metade século XVII, quando Bodin concluiu que o estudo do passado, e das causas que levaram aos eventos, era fundamental para que se entendesse o presente. No século XVIII, o avanço intelectual representava o progresso do homem. Na segunda metade do século, paralelamente à idéia de progresso, outros conceitos foram surgindo, como igualdade, justiça social e soberania popular. Os pensadores deixavam de lado a influência de Deus e abriam espaço para que o progresso se realizasse por meio da ação humana. (DUPAS, 2006).

Com a Revolução Industrial, ocorrida na Inglaterra em meados do século XVIII, o mundo entra na chamada Era Moderna. Foi nessa época que a visão de progresso começou a ser associada ao crescimento econômico, ao domínio da natureza, ao trabalho e à satisfação das necessidades humanas. No decorrer do tempo essa idéia foi incorporada a todas as atividades humanas, e a cada conquista tecnológica ela se reforçou, de modo que seu significado passou a ter relação com o crescimento 
industrial e com o consumo de bens por parte da população. O objetivo econômico passou a ser o consumo em massa, e junto com ele a transformação de produtos em objetos de desejo; e, por conseqüência, auxiliado pela idéia de que os recursos da natureza eram infinitos, ocorreu o que pode se chamar de desperdício em massa. Somente após a Segunda Guerra Mundial atentou-se para a finitude dos recursos naturais e, embora ainda hoje o mercado global mantenha fortemente a política de consumo de massa, há o início de uma consciência sobre os problemas do consumo desenfreado.

A idéia de desenvolvimento está mais ligada ao crescimento, à ampliação e ao incremento, do que à melhoria. A existência de desenvolvimento não necessariamente melhora o estado de algo, mas expande, amplia. Portanto, o desenvolvimento pode não ser acompanhado por um progresso, uma vez que a existência de desenvolvimento pode não trazer conseqüências benéficas ou favoráveis. De um modo geral, temos a idéia de que no decorrer dos últimos dois séculos a vida de toda população melhorou. Tivemos acesso a novas tecnologias, os esforços físicos se tornaram menores para todas as atividades humanas, tivemos mais conforto, conseguimos nos locomover em menos tempo e grande parte da população mundial, por meio da rede internacional de comunicação, a internet, pôde ter acesso a toda e qualquer informação. No mundo globalizado, conforme observa Gilberto Dupas em $O$ Mito do Progresso, "sempre acessível e conectado" passou a ser o lema do progresso; sentimo-nos culpados e temos de justificar quando não estamos disponíveis ou "ligados". O próprio Dupas faz a pergunta que merece reflexão: "somos, por conta desse tipo de desenvolvimento, mais sensatos e mais felizes?" (DUPAS, 2006). Em nome do progresso, gerou-se, também, exclusão, pobreza extrema e devastação ambiental. A máquina do desenvolvimento não deu suporte a todos os habitantes do planeta. Cabe considerar que o mundo se desenvolveu, mas talvez não tenha progredido dos pontos de vista social, ambiental e até mesmo econômico, já que a economia se posicionou a favor da parcela da população já favorecida economicamente. 
Em conferência durante o Fórum Social Mundial, realizado em Porto Alegre em janeiro de 2010, David Harvey, professor de Geografia e Antropologia da City University, de Nova Iorque, ao discutir sobre a evolução do sistema capitalista de desenvolvimento, afirma que "o comunismo fracassou, o capitalismo triunfou e cresceu dominando o mundo e, paralelamente ao desenvolvimento tecnológico, produziu exclusão social, pobreza, fome, destruição ambiental e guerras. Houve aumento da desigualdade social, cresceu a corrupção da democracia pelo poder do dinheiro, a mídia se transformou em cúmplice dessa corrupção da democracia, houve aceleração da destruição ambiental e crises econômicas foram geradas pelo surgimento do capital fictício. Fundamentalmente, a vida diária tem que mudar, as relações sociais têm que mudar. Deve haver um crescimento das idéias anti-capitalistas. Deve-se propor a bandeira do "outro mundo é possível"'". Nesse outro mundo possível, o desenvolvimento deve ser acompanhado de preservação ambiental, justiça social e avanço econômico.

Neste trabalho, decidimos esclarecer o significado dos termos "desenvolvimento" e "progresso" como forma de embasamento para a discussão final sobre a evolução da atividade de construção. Mais adiante, no capítulo 5, onde constam as considerações finais desta pesquisa, serão comentados os aspectos que compõem a arquitetura atual das cidades e que são resultado do desenvolvimento da atividade de construção nas últimas décadas. Tentaremos dar uma contribuição com possíveis respostas para as perguntas:

1. A arquitetura brasileira está progredindo na busca por soluções que tragam mais qualidade às construções e diminuam os impactos ambientais e urbanos?

2. Estamos tendo uma melhora na maneira de lidar com aspectos sociais, ambientais e econômicos dentro da atividade de construção?

3. Existe uma maneira de promover preservação ambiental e justiça social, além de retorno financeiro no mercado imobiliário? 


\subsection{Impactos Ambientais da Atividade de Construção}

Em maio de 2007 o IPCC (Intergovernmental Panel on Climate Change) lançou um relatório alarmante sobre o aumento do efeito estufa e apontou as atividades que mais colaboram na emissão de gases nocivos à camada de ozônio. Entre elas, a atividade de construção é tida como responsável por $8 \%$ dessas emissões, colaborando significativamente para o aquecimento global. Este número não inclui a contribuição de outros participantes da cadeia produtiva da atividade de construção e o consumo de energia, que consta individualmente no relatório como o principal responsável pelos danos ambientais do planeta, com 25\% das emissões. Em segundo lugar está a atividade industrial (20\%), seguida pelo desmatamento de florestas (17\%), pelo setor agropecuário (14\%), transportes (13\%), setor de construção (8\%) e rejeitos sólidos e líquidos (3\%) (Gráfico 2.1).

\section{Gráfico 2.1. Quanto cada setor contribui para o efeito estufa (no mundo)}

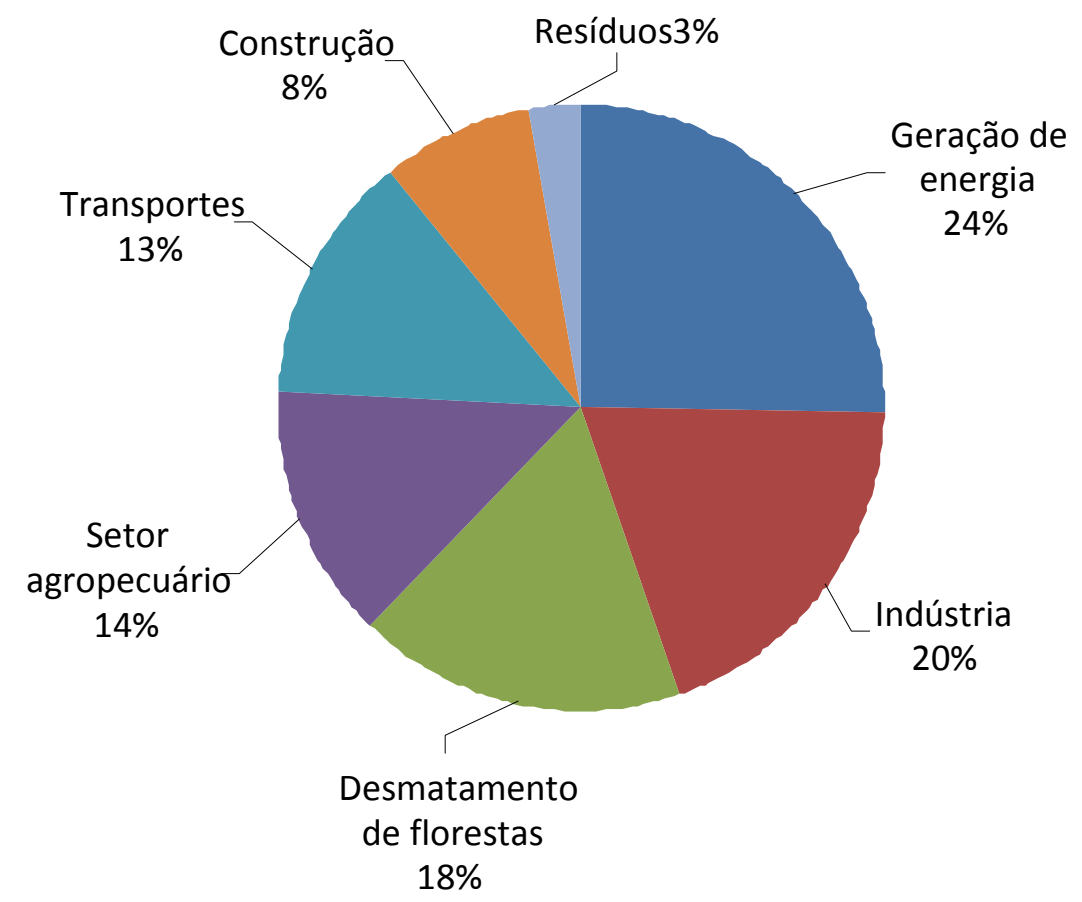


Se considerado o consumo de energia em edifícios dentro da atividade de construção, o setor se torna responsável por uma enorme parcela de contribuição ao aquecimento global, consumindo a maior parte de todos os recursos naturais do planeta. Brian Edwards, em Guía Básica de La Sostenibilidad, publicado em 2004, aponta os principais recursos consumidos na atividade de construção, em todo o mundo (tabela 2.2).

Tabela 2.2 - Recursos consumidos na atividade de construção

\begin{tabular}{|c|c|}
\hline RECURSO & CONSUMO \\
\hline MATERIAIS & $50 \%$ de todos os recursos mundiais destinam-se ao setor de construção \\
\hline ENERGIA & $\begin{array}{l}\text { 45\% da energia gerada é utilizada no aquecimento, iluminação e } \\
\text { ventilação de edifícios. } 5 \% \text { é utilizada para sua construção }\end{array}$ \\
\hline ÁGUA & $\begin{array}{l}40 \% \text { da água utilizada no mundo é destinada ao abastecimento das } \\
\text { instalações sanitárias e outros usos dos edifícios }\end{array}$ \\
\hline TERRA & $60 \%$ da superfície da terra cultivável é utilizada em construções \\
\hline MADEIRA & $\begin{array}{l}70 \% \text { dos produtos derivados da madeira são destinados à construção } \\
\text { de edifícios }\end{array}$ \\
\hline
\end{tabular}

O setor de construção está no centro da crise ambiental. Nos últimos cinco anos observou-se um crescimento significativo no volume de construções em países em processo de desenvolvimento, principalmente no Brasil, China e Índia (Gráficos 2.2 e 2.3). Esse crescimento é resultado de uma série de fatores econômicos favoráveis ao investimento em construção e do fato desses países possuírem um déficit habitacional elevado. Segundo a OECD (Organisation for Economic Co-operation and Development) entidade que reúne as economias mais prósperas, se os países emergentes mantiverem o ritmo de crescimento atual, em 2030 o Brasil, China, Índia e Rússia emitirão mais dióxido de carbono $\left(\mathrm{CO}_{2}\right.$, o principal gás causador do efeito estufa) do que todos os trinta países desenvolvidos que fazem parte da organização. Existe, atualmente, uma discussão que leva em conta, prioritariamente, a interrupção desse processo de degradação ambiental, por meio de políticas que impedem o crescimento 
acelerado dos países em desenvolvimento. No entanto, a idéia de que esses países emergentes não poderão crescer economicamente, como aconteceu com os países já desenvolvidos, os quais não levaram em conta aspectos ambientais no seu processo de crescimento, gera controvérsias e impede que haja um acordo entre todas as partes, que promova, de fato, uma contenção dos impactos ambientais causados pelo processo de desenvolvimento.

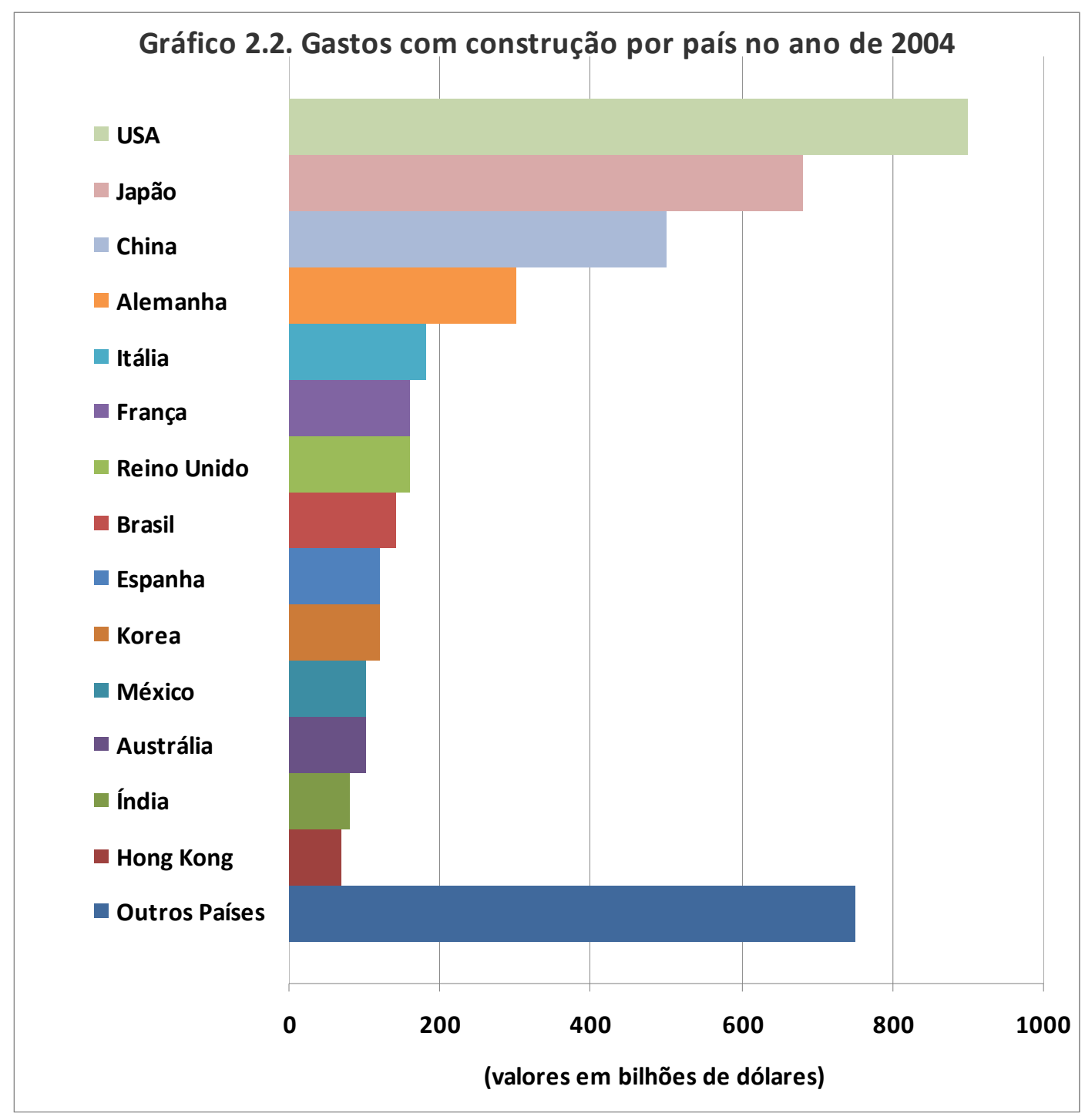

Fonte: UNEP, 2007 


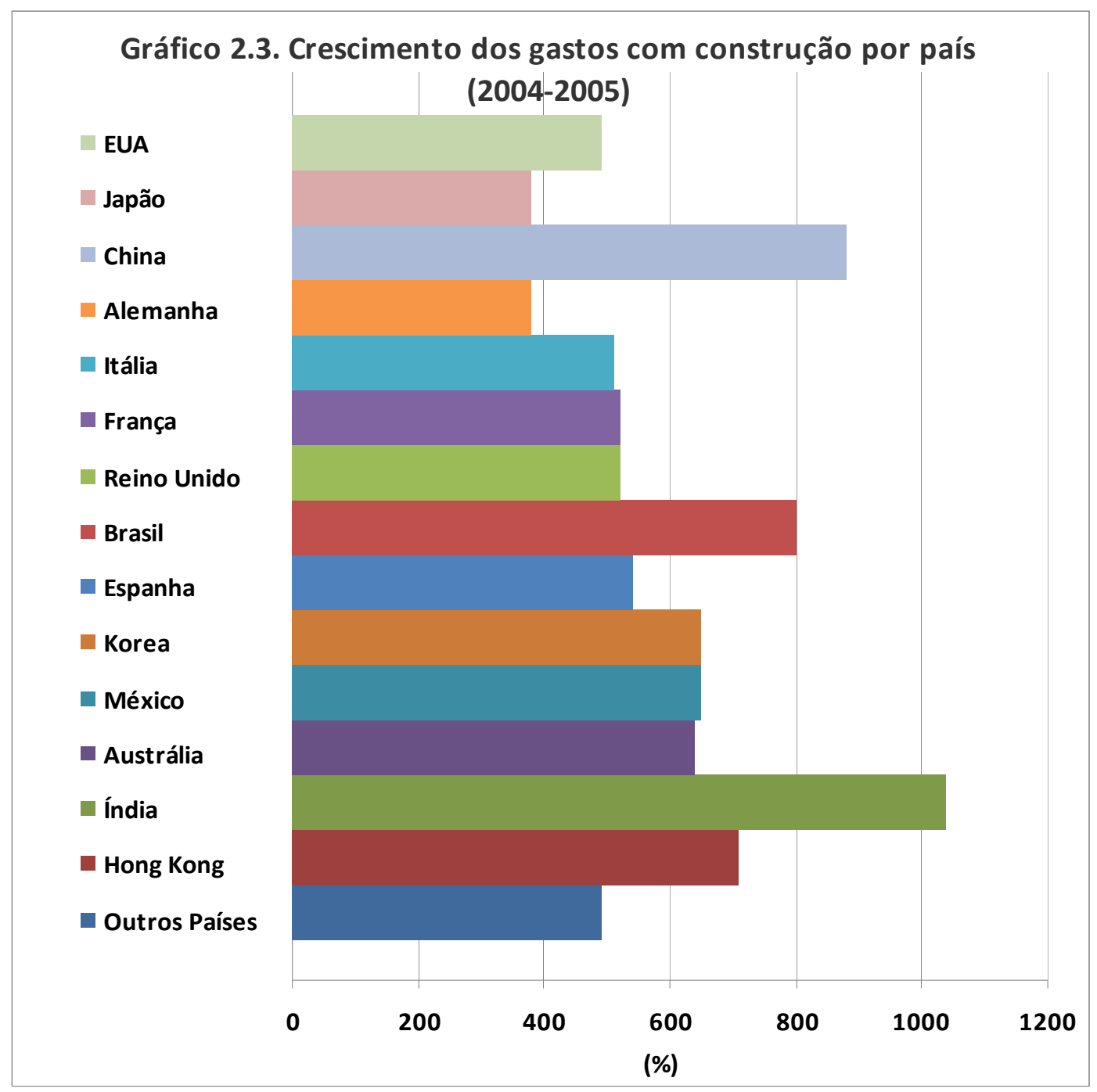

Fonte: UNEP, 2007

A atividade de construção não contribui somente para o aumento do aquecimento global. Dentro da atividade de construção, inúmeros impactos ambientais e sociais colaboram para que o desenvolvimento não se faça de maneira benéfica para a sociedade e o meio ambiente. Entre as atividades do setor de construção, as mais agressivas ao meio ambiente são:

- consumo de matérias-primas naturais, que são extraídas, transportadas, processadas, e novamente transportadas para o local da obra; 
- construção e demolição de edifícios, que geram grande quantidade de resíduos;

- alto consumo de energia elétrica e água na fase de operação dos edifícios.

De forma mais abrangente, são listados abaixo os impactos ambientais negativos da atividade de construção (SILVA; RODRIGUES; PINHEIRO, 2008):

1. A construção e a manutenção da infra-estrutura do país consomem até $75 \%$ dos recursos naturais extraído, sendo a cadeia produtiva do setor de construção a maior consumidora desses recursos.

2. A quantidade de resíduos de construção e demolição é muito elevada, gerando impactos no ambiente urbano e nas finanças municipais.

3. Os canteiros de obras são responsáveis por gerar grandes quantidades de poeira e ruído, e causam erosões que prejudicam o sistema de drenagem natural da água.

4. A construção causa diminuição da permeabilidade do solo, mudando o regime de drenagem, causando enchentes e reduzindo as reservas de água subterrânea.

5. A utilização de madeira extraída ilegalmente para fins construtivos, além de comprometer a preservação das florestas, representa séria ameaça ao equilíbrio ecossistêmico.

6. A cadeia produtiva da construção contribui para a poluição, inclusive na liberação de gases do efeito estufa, como $\mathrm{CO}$, durante a queima de combustíveis fósseis, e a descarbonatação de calcário e de compostos orgânicos voláteis, que afetam também os usuários dos edifícios.

7. Contaminação ambiental pela lixiviação de biocidas e metais pesados contidos em alguns materiais de construção.

8. A operação de edifícios no Brasil é responsável por cerca de $18 \%$ do consumo total de energia e por $50 \%$ do consumo de energia elétrica.

9. Os edifícios brasileiros gastam $21 \%$ da água consumida no país, sendo boa parte desperdiçada (Fonte: Conselho Brasileiro da Construção Sustentável).

10. Segundo pesquisa da Escola Politécnica da USP (2001), a construção desperdiça, em média, nas obras, $56 \%$ de cimento, $44 \%$ de areia, $30 \%$ de gesso, $27 \%$ dos condutores e $15 \%$ dos tubos de PVC e eletrodutos. 
O setor também gera problemas sociais, como a baixa remuneração dos trabalhadores, o impacto na qualidade de vida da vizinhança, elevada taxa de informalidade, como por exemplo, na venda de materiais de construção sem nota fiscal, com baixa qualidade e na existência de funcionários sem registro (JOHN, 2008). A informalidade é um aspecto essencial para o alcance da sustentabilidade. Ela não é uma questão individual, mas coletiva, social. No Brasil, a informalidade está incorporada à nossa cultura, nos costumes da sociedade. As conseqüências ambientais são óbvias: a redução da arrecadação do Estado afeta sua capacidade de investimento, prejudicando a infra-estrutura coletiva e o aparato estatal, inclusive a fiscalização de reservas ambientais e as políticas sociais. As conseqüências ambientais são evidenciadas pela tragédia ambiental nacional, o desmatamento da Amazônia. Sem a redução da informalidade não é possível introduzir políticas de construção sustentável de forma consistente (JOHN, 2007).

A introdução dos conceitos de sustentabilidade na atividade de construção surgiu como alternativa para a diminuição dos problemas gerados durante todo o ciclo de vida dos edifícios. Segundo a Association Haute Qualité Environnementale, a interação do edifício com o meio ambiente se dá em momentos distintos de sua existência e envolve diferentes agentes da cadeia produtiva, entre eles os projetistas (HQE, 2008). O conceito de análise do ciclo de vida (LCA - Life Cycle Analysis), originalmente desenvolvido na esfera da avaliação de impactos de produtos, sustentou o desenvolvimento das metodologias para avaliação ambiental de edifícios que surgiram na década de 90 na Europa, nos Estados Unidos e no Canadá como parte das estratégias para cumprimento das metas ambientais locais estabelecidas a partir da ECO'92 (SILVA; SILVA; AGOPYAN). O ciclo de vida de um edifício contempla as seguintes etapas: idealização/planejamento, concepção/projeto, construção/implantação, uso/operação, e requalificação/demolição.

Idealização / Planejamento - fase inicial do ciclo de vida de um edifício, na qual o empreendimento é concebido. Nesta etapa são realizados estudos de viabilidade física, 
econômica e financeira. São feitos, também, estudo de legislação, estudo das condições naturais e entorno.

Concepção / Projeto - esta fase envolve todas as atividades entre o pré-projeto e o início da construção do empreendimento. São elaborados os projetos e suas especificações, bem como a programação do desenvolvimento das atividades construtivas.

Construção / Implantação - é a fase de construção do edifício. Nesta fase, o canteiro de obras deve funcionar de acordo com o planejado nas etapas anteriores.

Uso / Operação - é a fase de operação do empreendimento, etapa em que ele é ocupado por seus usuários. Também é o período em que há necessidade de reposição de componentes que atingiram o final de sua vida útil e de manutenção de equipamentos e sistemas, ou então em que há necessidade de correção de falhas de execução, patologias, ou ainda modernização do empreendimento e adequação a alterações de comportamento do usuário.

Requalificação / Demolição - é a etapa final de vida do edifício. Nesta fase o edifício passa por uma requalificação, para adequação a um novo uso, ou é demolido.

A etapa de idealização e planejamento, se bem realizada, pode garantir o sucesso de todo o ciclo de vida do edifício. Nesta etapa devem ser tomadas as decisões necessárias para que o processo de construção e ocupação ocorra de maneira eficiente. Os planejadores do empreendimento têm, nessa fase inicial, todas as possibilidades de interferência no custo total do edifício, de modo que devem ser tomadas decisões para que os custos adicionais de um empreendimento mais sustentável, que variam entre $5 \%$ e $8 \%$ do valor da obra, tenham retorno durante a etapa de uso e operação. Decisões tomadas após o início do projeto e interferências tardias terão restrições para se realizar, uma vez que levarão à obrigatoriedade de um retrabalho. Quanto mais avançado estiver o estágio do empreendimento, mais difícil será interferir em seu custo total (Gráfico 2.4). 


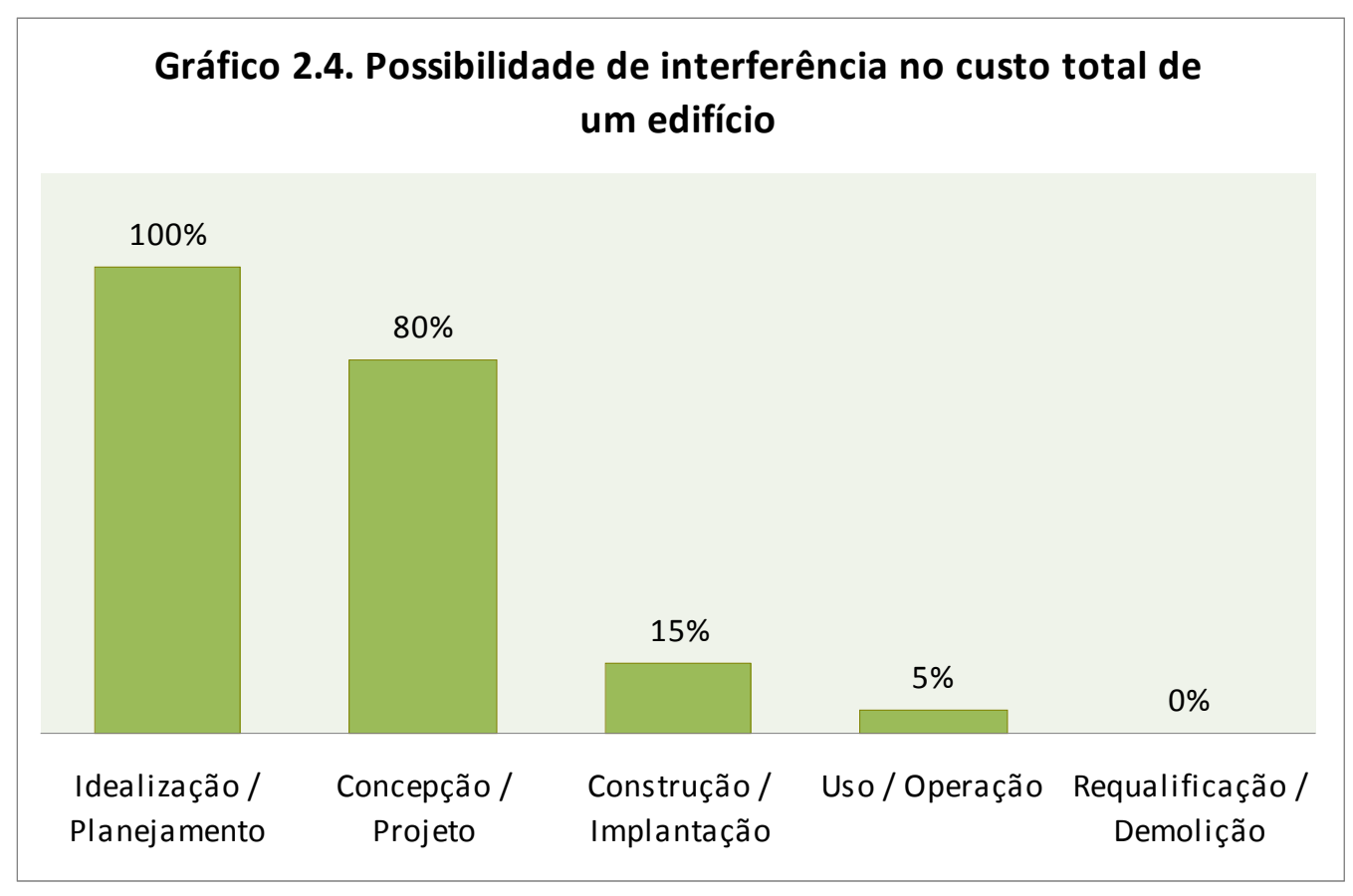

Fonte: CEOTTO, 2008

Um edifício residencial de médio padrão, planejado para ser eficiente no uso dos recursos naturais, gerará uma economia que pode chegar a (CEOTTO, 2008):

$50 \%$ no consumo de água;

$40 \%$ no consumo de energia elétrica;

$35 \%$ no valor do condomínio.

Para a cidade e a população, os impactos das construções afetam diretamente suas atividades, fazendo diminuir a qualidade de vida e agravando aspectos sociais e de infra-estrutura, como engarrafamentos, alagamentos, crescentes índices de poluição ambiental, sonora e visual, alterações climáticas de temperatura, umidade, índices pluviométricos e, ainda, inúmeros efeitos sobre a saúde física e mental dos habitantes (SANTANA, 2009). A recente arrancada do setor imobiliário colabora para o agravamento desses problemas, obrigando as empresas que fazem parte do processo construtivo a repensarem seu modo de produção.

Existem cerca de 6,8 bilhões de habitantes no mundo e estima-se que em 2050 a população mundial chegará a 10 milhões de pessoas. Dentro dessa perspectiva, 
teremos dificuldade para manter toda a população em boas condições de sobrevivência, futuramente. Atualmente, já há sérios problemas de falta de recursos básicos, como água, para algumas populações em países pobres. A formação dos grandes centros urbanos subdesenvolvidos, com mais de 10 milhões de habitantes, também reforçou a urgência de um novo modelo de desenvolvimento, mais justo socialmente e menos agressivo ao meio ambiente. Dentro da atividade de construção, o primeiro conceito que deve ser incorporado a um novo modo de produção como forma de minimizar os problemas ambientais são os "quatro erres": reduzir, reutilizar, reciclar e reabilitar (Tabela 2.3).

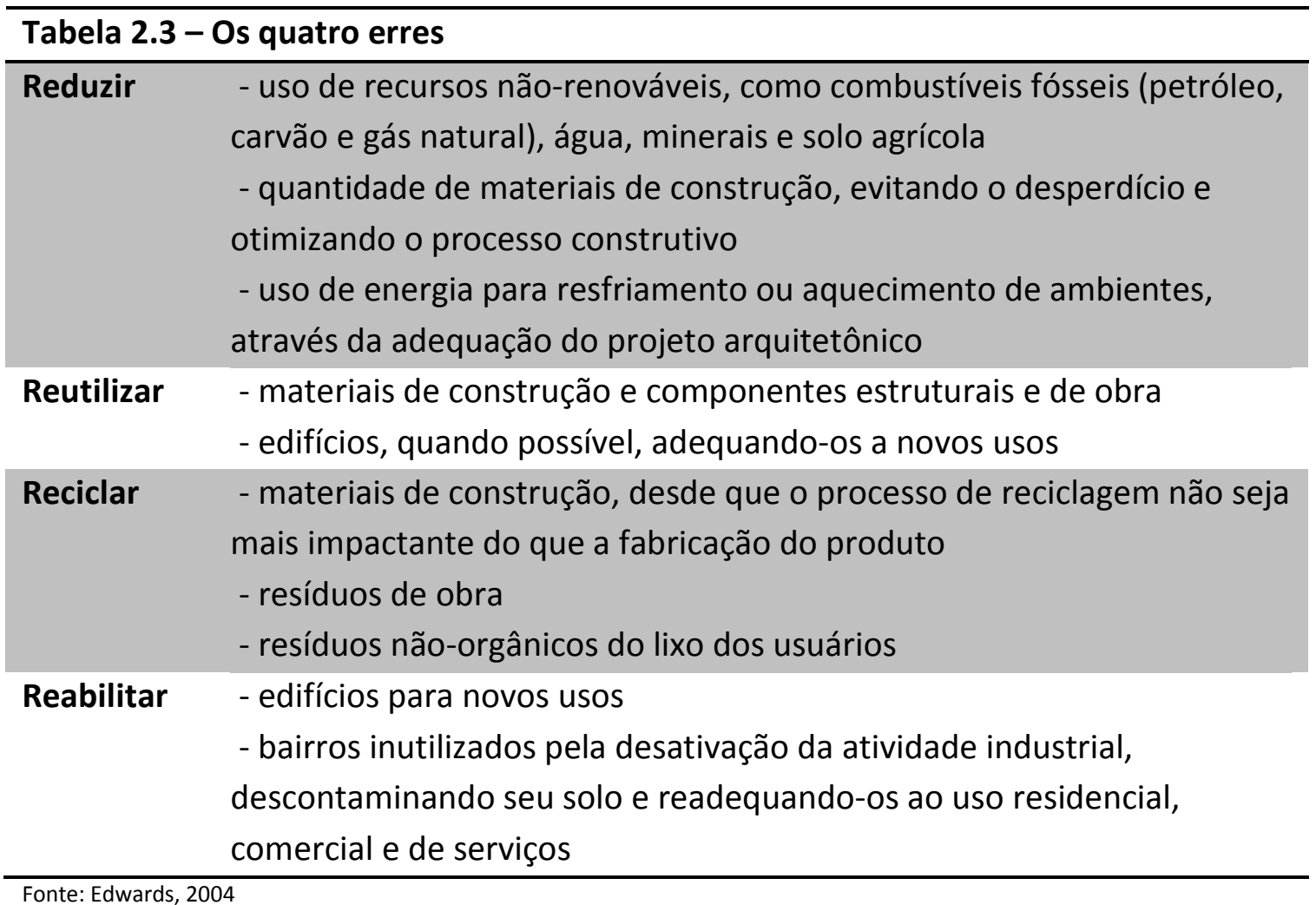

Para os agentes ligados à atividade de construção, a incorporação dos "quatro erres" deve ocorrer de forma integrada, não somente quanto ao planejamento em conjunto dos empreendimentos, com a participação de todos os profissionais que formam a cadeia da construção, mas também individualmente, dentro de cada área profissional. No caso dos arquitetos e projetistas, as propostas para redução, reutilização, reciclagem e reabilitação devem estar inseridas no projeto de arquitetura 
de forma prioritária, e esses profissionais devem ter a capacidade de expor a importância desses aspectos para os empreendedores e investidores do mercado de construções.

A atividade de construção é a grande transformadora da paisagem urbana e faz parte de um conjunto de ações humanas que, ao longo da história das cidades, destruiu grande parte do ambiente natural do planeta. Atualmente, metade de toda a população mundial vive em cidades. O crescimento da população urbana, por todo o mundo, e os padrões, a grosso modo, insuficientes de moradia estão acelerando a taxa de aumento da poluição e erosão. É uma ironia que as cidades, o habitat da humanidade, caracterizem-se como o maior agente destruidor do ecossistema e a maior ameaça para a sobrevivência da humanidade no planeta (ROGERS, 2005).

A crise ambiental que estourou recentemente é a conseqüência direta do comportamento humano sobre a Terra. Como sugere Dupas, a ameaça mais grave à humanidade neste início de século XXI é o ataque sem trégua ao meio ambiente, decorrente da lógica da produção global e da direção de seus vetores tecnológicos contidos nos atuais conceitos de progresso. Hoje a natureza se converteu num problema ético; ela está tão degradada por ações humanas que a nossa relação com ela converteu-se em problema decisivo na constituição do ser, afetando as condições de vida sociais e a possibilidade de sobrevivência futura da espécie. Urge uma nova ética de responsabilidade, informada por um saber que ilumine as conseqüências deliberadas da ação humana (DUPAS, 2003). 
3. MERCADO IMOBILIÁRIO E SUSTENTABILIDADE 


\subsection{A Sustentabilidade na Produção das Décadas de 50, 60 e 70}

O período entre o final da década de 1940 e o início da década de 1970 caracteriza-se por um grande crescimento econômico do país, com um quadro de inflação baixa, oferta de empregos em alta e desenvolvimento da indústria. Na cidade de São Paulo, o aumento da população urbana inicia os processos de expansão periférica e verticalização das áreas centrais. A atividade de construção, que até o início da década de 1940 era voltada, em sua maior parte, para a construção de habitações para aluguel, após alterações na Lei do Inquilinato, em 1942, passou a se direcionar para o mercado de compra e venda. A Lei do Inquilinato tinha como principal finalidade congelar o valor dos aluguéis, de modo que o custo de vida não aumentasse, evitando-se assim, o aumento dos salários dos trabalhadores. O objetivo principal do governo, com a instituição dessa lei, era preservar recursos para promover a industrialização do país. Como resultado, o investimento em habitações de aluguel deixou de ser interessante para os agentes do mercado imobiliário, o que fez com que a produção se voltasse para a construção de moradias para a classe média da população, que naquele momento estava aumentando seu poder de consumo.

A experiência adquirida pelo morador que, advindo da moradia por aluguel do período rentista, moradia esta construída para durar no tempo e competir no mercado com o mínimo de manutenção, ensinou-o a apurar a qualidade. Quando esse locatário passou a comprador, havia um hábito que, por comparação, constituiu a exigência de utilização dos mesmos parâmetros de espaço e técnica aos quais esses moradores tinham se acostumado nas moradias edificadas no período anterior (FONSECA, 2006). Este é um dos motivos pelos quais a qualidade se manteve no início da produção imobiliária para o mercado de compra e venda.

Nesse período surgiu a figura do incorporador, um fato importante para o crescimento do mercado imobiliário na época, que passava a funcionar dentro das regras do capitalismo moderno, tornando-se atraente para a reprodução de capital. A atividade de incorporação consiste no controle econômico de todo o processo de 
construção, fazendo-se presente desde a compra de terrenos até a contratação de consultoria, planejadores, construtores, agentes financeiros, promotores de venda, etc. A existência de um agente que responde pelo capital investido, por todo o processo de construção e por eventuais problemas durante e após a execução da obra, tornou a atividade de construção mais dinâmica e permitiu ao mercado se organizar para atender aos compradores, após o fim do período rentista.

A partir de 1950 são formados grupos incorporadores ligados a instituições bancárias, companhias seguradoras e de capitalização, e construtoras, que, com uma demanda de compradores exigentes, sob a forte competição do mercado por preço baixo e maior pressão ainda por espaços adequados, construídos de modo econômico visando viabilizar o comprador, foram responsáveis por uma vasta produção de edifícios, caracterizados por sua alta qualidade e compromisso com o espaço urbano. A existência, entre os arquitetos, de um pensamento modernista muito presente, também adicionou qualidade à produção imobiliária nesse período, contribuindo para uma qualidade de linguagem e um compromisso com a sociedade e com a cultura, que transcende a questão mais emblemática de um estilo ou uma tendência, ou questões técnicas, como a qualidade dos materiais empregados (FONSECA, 2006).

Segundo Fonseca (2006), um ponto essencial da questão da qualidade da edificação está na sua capacidade de agregar valor ao espaço urbano que a contém. Os principais fatores condicionantes da qualidade na produção das décadas de 50, 60 e 70 são: pertinência do programa de necessidades com a demanda estabelecida, adequação espacial e formal, cuidados com a fachadas e empenas na absorção das escalas urbanas do entorno, uso de materiais e componentes construtivos de qualidade, e, principalmente, as relações que o edifício e o lote estabelecem com a cidade, propondo a interação entre ambos (FONSECA, 2006). Corbella e Yannas (2003), no livro "Em Busca de uma Arquitetura Sustentável para os Trópicos", denominam a arquitetura praticada nesse período como "Arquitetura Bioclimática", pois considera a integração do edifício à totalidade do meio ambiente, de forma a torná-lo parte de um conjunto maior. É a arquitetura que quer criar prédios objetivando o aumento da 
qualidade de vida do ser humano no ambiente construído e no seu entorno, integrado com as características da vida e do clima locais, consumindo a menor quantidade de energia compatível com o conforto ambiental, para legar um mundo menos poluído para as futuras gerações (CORBELLA \& YANNAS, 2003). Os edifícios construídos nessa época são, até os dias atuais, referência de boa arquitetura e qualidade construtiva. São exemplos dessa produção os empreendimentos (Figuras 3.1 a 3.10):

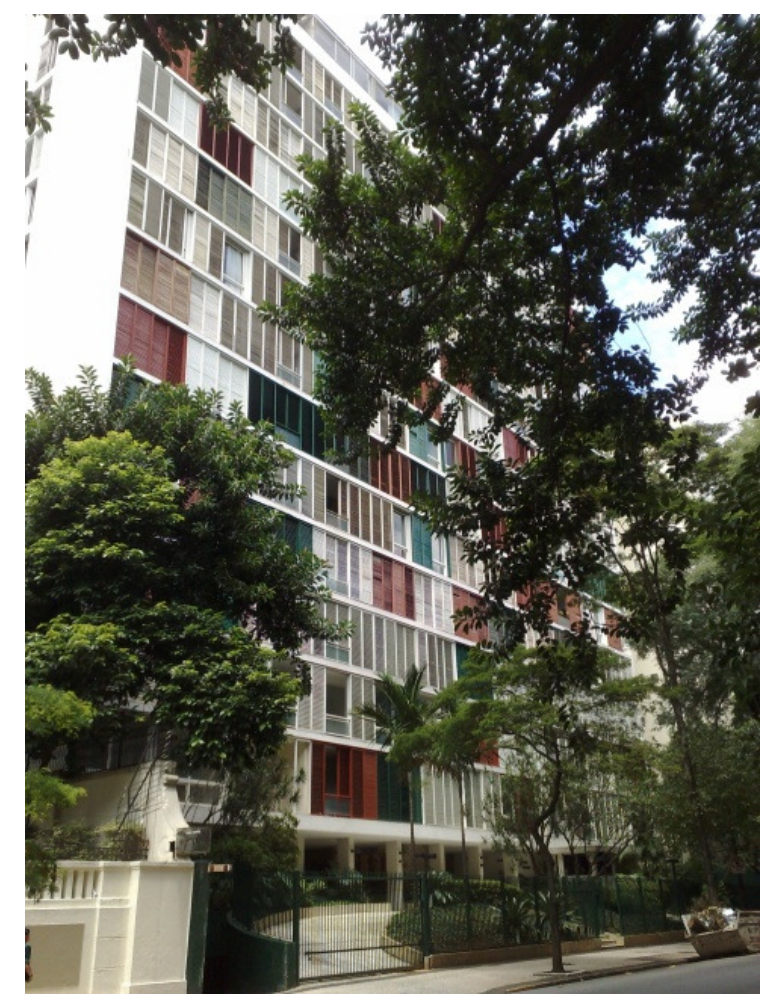

Figura 3.1 - Edifício Lausanne | Av. Higienópolis (foto da autora, 2010)
Edifício Lausanne, construído em 1958 pela Incorporadora e Construtora Otto Meinberg, com projeto arquitetônico de Adolf Franz Heep, caracteriza-se pelo programa compacto e métodos avançados de racionalização, com plantas bem resolvidas e eficácia nas soluções para iluminação e ventilação. Como na maioria dos bons edifícios construídos na época, o pavimento térreo consolida uma relação com o espaço público, e contém painéis do artista Clóvis Graciano. 


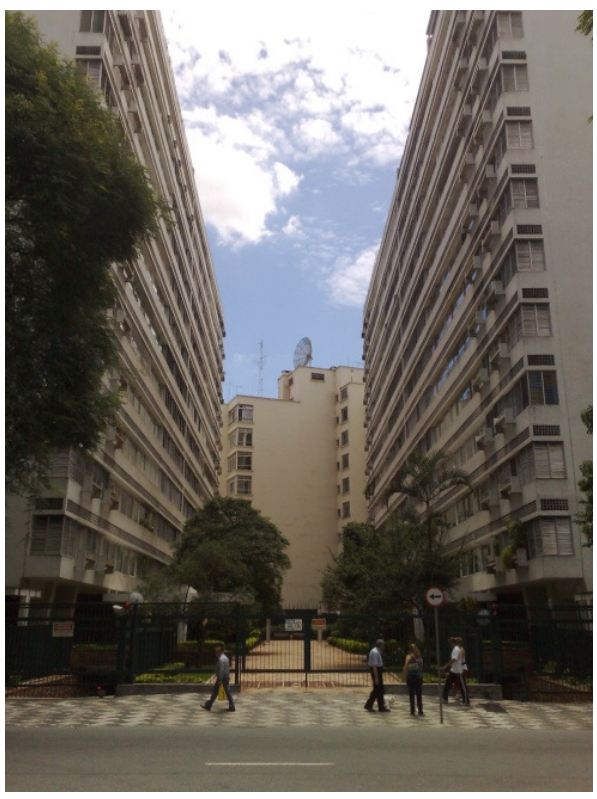

Figura 3.2- Edifício Lugano / Locarno | Av. Higienópolis (foto da autora, 2010)

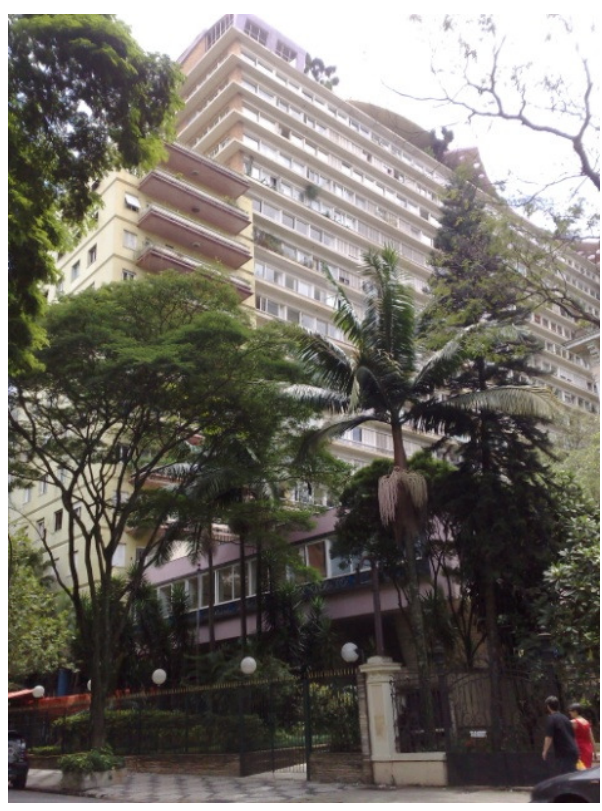

Figura 3.3 - Edifício Bretagne | Av. Higienópolis (foto da autora, 2010)
Edifício Lugano / Locarno, também construído em 1958, com projeto do arquiteto Adolf Franz Heep. As torres implantadas nas duas extremidades do lote liberam o espaço central do terreno para uso comum, criando uma via interna ao lote, dando a agradável impressão de continuação da rua que chega perpendicularmente ao terreno. Este é um dos exemplos de interação entre espaço externo e interno, e de compromisso com a cidade.

Edifício Bretagne, construído em 1959, pela Construtora Monções, com projeto de João Artacho Jurado. O edifício é uma das obras mais valorizadas do repertório imobiliário da cidade de São Paulo, pela qualidade do projeto e dos materiais empregados, e pela implantação do edifício no lote, em forma de "L", reservando boa parte do terreno para área de lazer e descanso. 


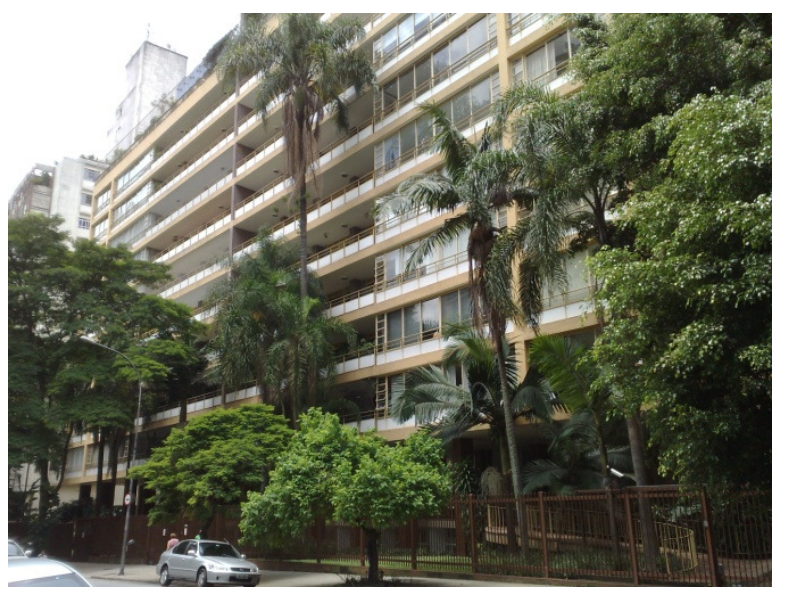

Figura 3.4 - Edifício Prudencia | Av. Higienópolis

(foto da autora, 2010)
Edifício Prudencia, construído em 1948 pela Incorporadora Prudencia Capitalização. O projeto arquitetônico de Rino Levi e Roberto Cerqueira César possui total flexibilidade na disposição dos cômodos da parte social e dos quartos, resultado da estrutura independente característica dos

projetos modernistas, apresentando variações na configuração das plantas dos apartamentos (MINDLIN, 1999). O edifício apresenta volume simples, com programa bem trabalhado. Existe, como em outros empreendimentos da época, uma interação entre o espaço público e o privado por meio do térreo livre.

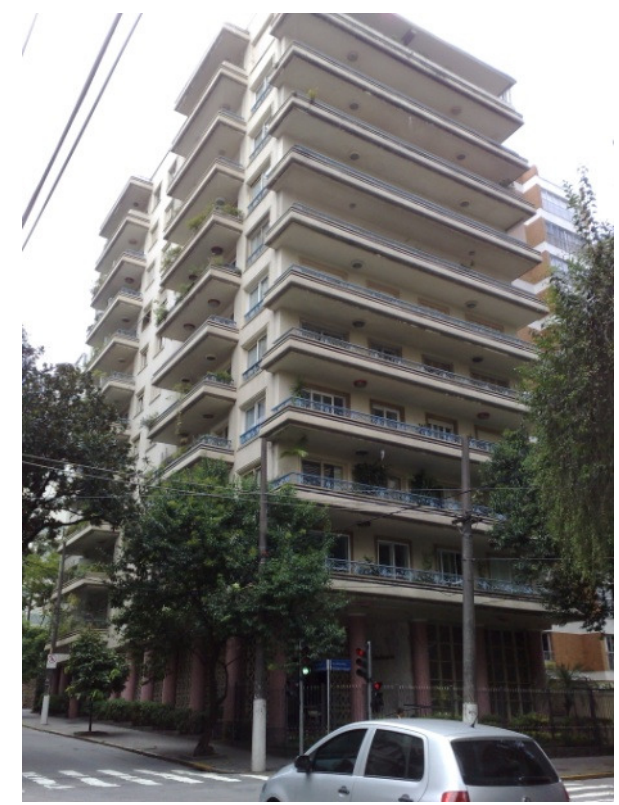

Figura 3.5 - Edifício Cinderela | Rua Maranhão (foto da autora, 2010)
Edifício Cinderela, construído em 1956 pela Construtora Monções, com projeto de João Artacho Jurado. Embora haja uma mistura de estilos (moderno, art-nouvel e clássico), com a utilização de elementos decorativos, há uma interpretação pessoal e particular dos elementos que compõem a arquitetura moderna dos anos 50 (FONSECA, 2006). O edifício se caracteriza pelo emprego de materiais de alta qualidade e pelo diálogo com o espaço urbano. 


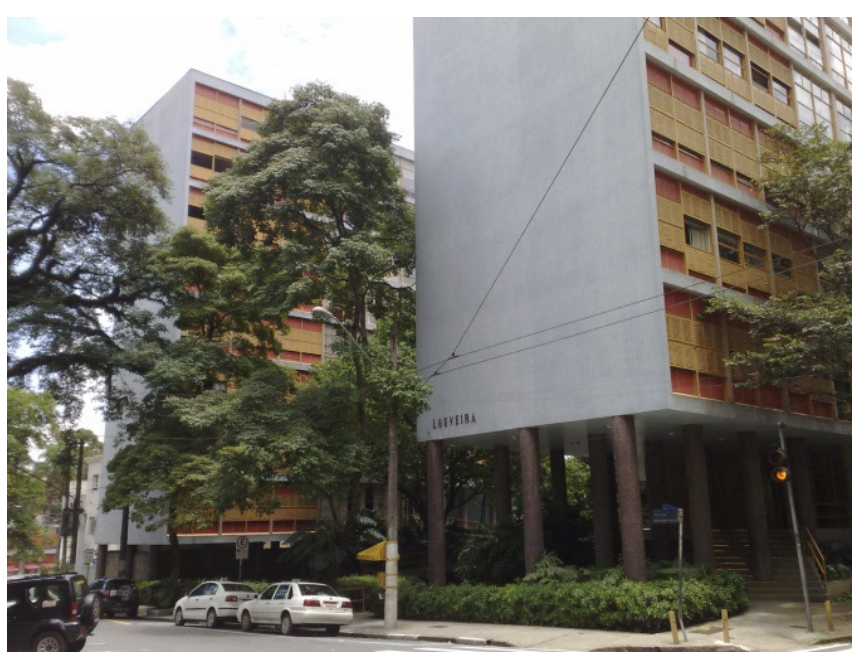

Edifício Louveira, construído em 1946, com projeto de J. B. Vilanova Artigas. O edifício é um exemplo de respeito ao espaço público, com volumes simples, porém, muito bem implantados, de modo a assegurar a melhor insolação possível aos ambientes sociais e aos quartos (MINDLIN, 1999).

Figura 3.6 - Edifício Louveira | Praça Vilaboim (foto da autora, 2010)

Existe uma clareza de formas e plantas projetadas com cuidado em relação à função (FONSECA, 2006). Foi pioneiro pela construção racionalista, pelo diálogo com o entorno urbano, e pela formação de um espaço semi-público que se tornou local de convívio para os moradores.

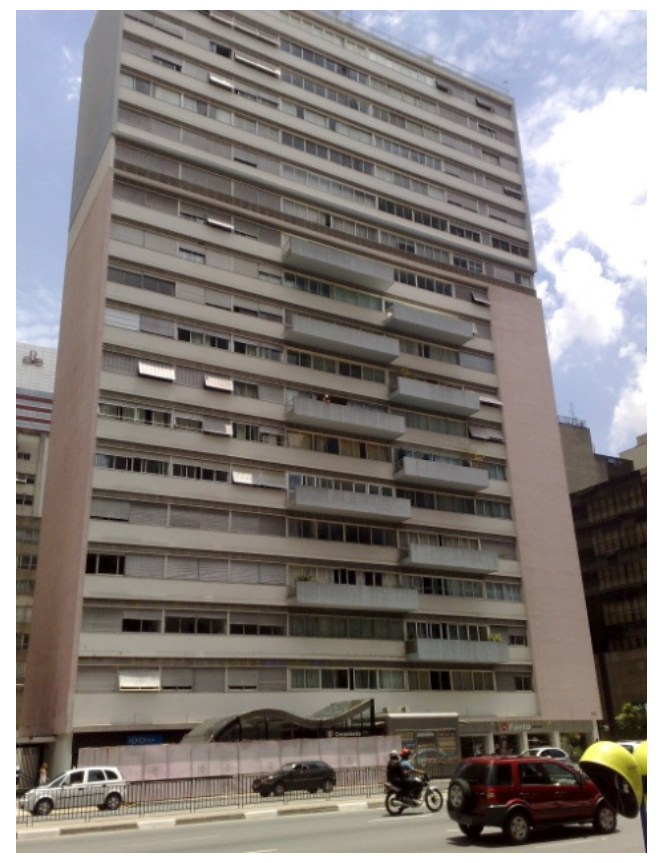

Figura 3.7 - Edifício Três Marias | Av. Paulista (foto da autora, 2010)
Edicício Três Marias, construído em 1952, projetado por Abelardo de Souza, se distingue pela qualidade na implantação, com volume de esquina em "L", e térreo ocupado por comércio e serviços. Uma característica dos edifícios construídos por grupos incorporadores nesse período é a agilidade na gestão dos recursos financeiros, em função da sua comercialização a preço de custo, ou seja, comercialização de todo o prédio ainda na planta, não havendo riscos futuros com relação a falta de recursos. 


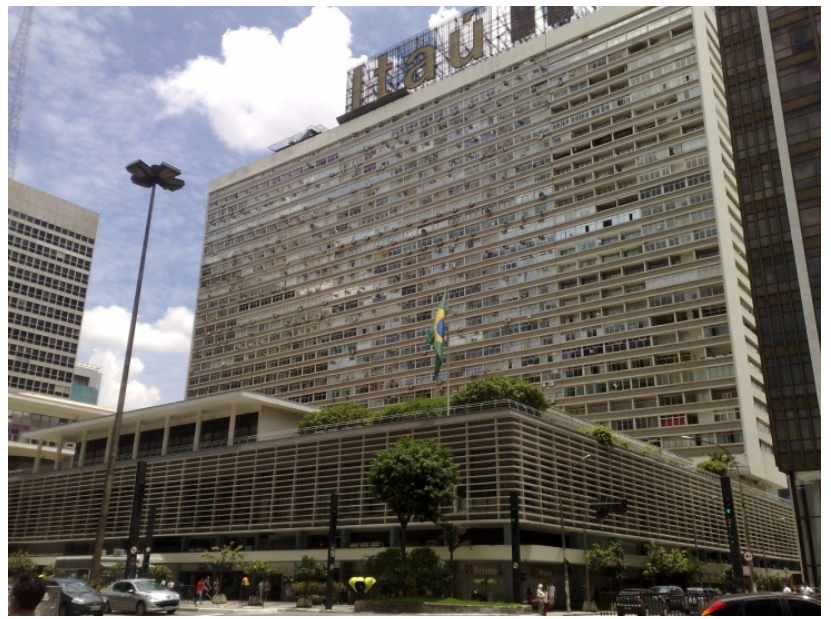

Edifício Conjunto Nacional, construído em 1955, com projeto de David Libeskind. A ocupação do terreno com um volume horizontal para fins comerciais, com a cobertura desse volume sendo utilizada como teto jardim e área comum para os moradores da torre de residências, criou um espaço

Figura 3.8 - Conjunto Nacional | A. Paulista (foto da autora, 2010)

multifuncional (com comércio, serviços, cultura e lazer) extremamente bem utilizado pela população. Os conceitos modernistas estão representados neste conjunto e seu compromisso com a qualidade em muito superam a questão pura do agenciamento de materiais com boa qualidade, emprego de mão-de-obra treinada e bons arranjos espaciais (FONSECA, 2006).

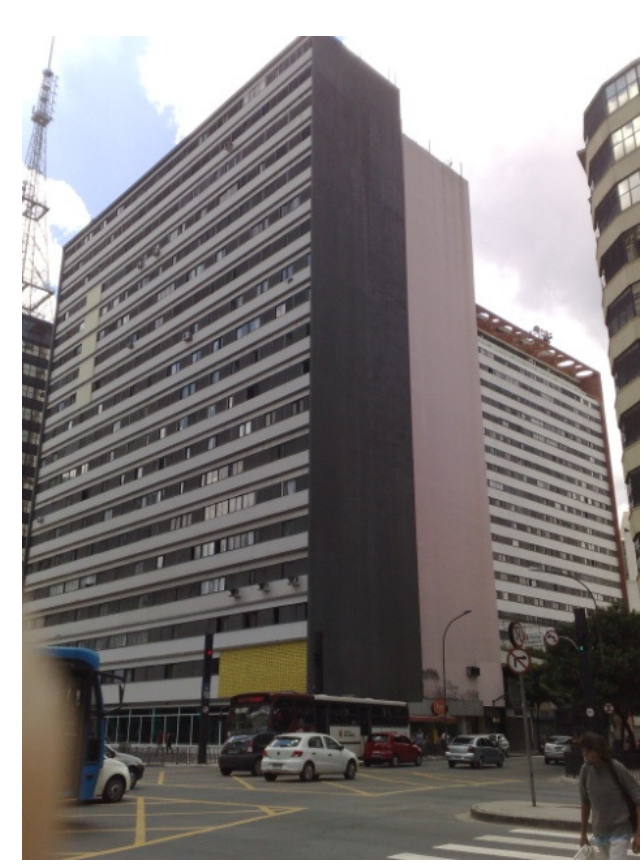

Edifício Nações Unidas, construído em 1956, projetado por Abelardo de Souza. O edifício implantado na esquina da Av. Paulista com a Av. Brigadeiro Luiz Antonio tem o térreo ocupado por comércio e serviços, com terraço jardim para uso comum com moradores. Um painel de azulejos de Clóvis Graciano foi colocado no térreo, possível de se visualizar passando pela calçada. Com arquitetura livre de exageros, elementos industrializados como esquadrias e venezianas, e implantação moderna, o edifício é mais um exemplo de boa arquitetura no

mercado imobiliário.

Figura 3.9 - Edifício Nações Unidas | Av. Paulista c/ Brig. Luiz Antonio

(foto da autora, 2010) 


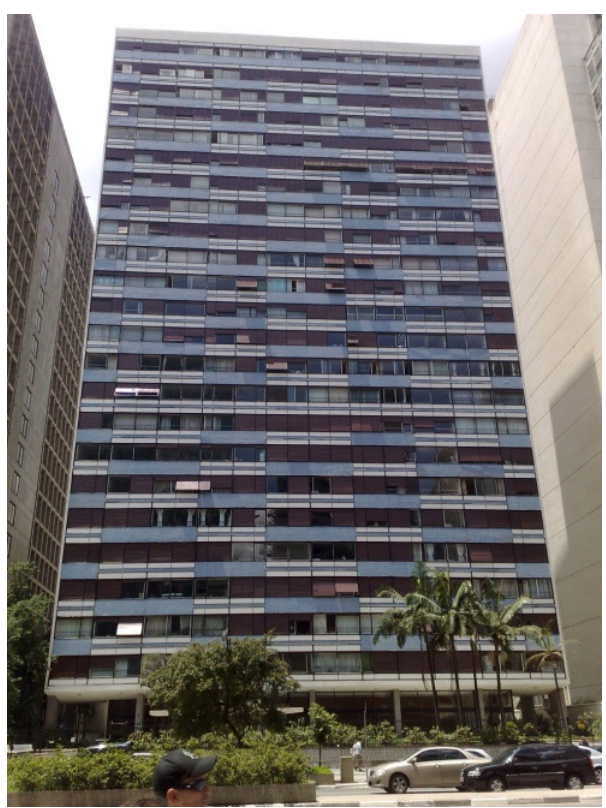

Figura 3.10 - Edifício Paulicéia | Av. Paulista (foto da autora, 2010)
Edifício Paulicéia, construído pela Sul América Capitalização, em 1955. O projeto de Gian Carlo Gasperinie e Jacques Pilon foi inovador para o mercado imobiliário naquele período. $\mathrm{O}$ uso da circulação vertical externa à laje principal do edifício passou a fazer parte de muitos edifícios residenciais nos períodos seguintes. Assim como os edifícios apresentados anteriormente, o projeto do Ed. Paulicéia se tornou referência de bom uso do espaço e arranjo dos ambientes para o mercado imobiliário residencial, e continua

sendo considerado uma referência até os dias atuais.

$\mathrm{Na}$ época em que foram construídos os edifícios apresentados, a preocupação geral com o desenvolvimento da indústria alavancou todos os setores da economia, entre eles, o setor de construção. O mercado imobiliário começava a dar grandes passos e empresas pequenas se tornaram grandes, do dia para a noite. Não havia, ainda, uma consciência ambiental na sociedade, assim como não há hoje; porém, o conceito de arquitetura abrangia muito mais intensamente o bem estar do usuário. Aspectos de conforto ambiental eram prioritariamente considerados na elaboração dos projetos e estão evidentes na maneira como os edifícios foram implantados no lote, no seu estado de conservação, na generosidade dos caixilhos, na conformação dos ambientes internos e externos, na simplicidade estética, mantendo-se atual, mesmo passados cinqüenta anos de sua construção. 
Para Corbella e Yannas, a Arquitetura Sustentável proposta atualmente deveria ser a continuidade mais natural da Arquitetura Bioclimática, realizada em meados do século passado, cujo objetivo era prover um ambiente construído com conforto físico, sadio e agradável, adaptado ao clima local, que minimizasse o consumo de energia convencional e precisasse da instalação da menor potência elétrica possível, o que também levava à mínima produção de poluição. As estratégias dos projetos arquitetônicos realizados naquele período, para conseguir um bom nível de conforto em clima tropical úmido, são (CORBELLA \& YANNAS, 2003):

1. Controle dos ganhos de calor, através da minimização da incidência direta do sol através das aberturas e por meio da absorção pelas paredes externas;

2. Dissipação da energia térmica do interior do edifício, por meio da disposição das aberturas, áreas dos ambientes adequadas e fechamentos de boa qualidade, promovendo níveis maiores de ventilação;

3. Remoção da umidade em excesso e movimentação do ar, com o posicionamento das aberturas de forma que haja ventilação cruzada, renovando o ar interno no período em que as pessoas estejam ocupando o ambiente;

4. Uso da iluminação natural, através do estudo da incidência solar na unidade, de modo que as aberturas deixem entrar a luz natural, sem permitir a entrada da radiação solar direta;

5. Controle do ruído, o qual se realizava dispondo elementos que dificultavam sua transmissão, tanto para ruídos provindos de fontes localizadas no próprio edifício, quanto para os gerados fora dele.

Os edifícios têm em comum, também, o fato de que no período em que foram construídos havia um desejo, por parte dos agentes ligados à atividade de construção, de que se criasse uma linha de produção, com a racionalização de materiais e componentes, de modo que a atividade pudesse dar um salto tecnológico, transformando todo o processo construtivo. A fabricação da maioria dos materiais e componentes dentro do país, após a Segunda Guerra Mundial, e o surgimento do concreto armado, permitiu que houvesse uma mudança no processo de construção 
dos edifícios. As possibilidades e recursos da indústria local aumentaram rapidamente, reduzindo, assim, a cada dia, os problemas técnicos de construção enfrentados pelo arquiteto. Antes era preciso importar quase todas as ferramentas, equipamentos e materiais de acabamento. Desse modo, houve um crescimento da padronização, com o aperfeiçoamento de produtos e métodos de fabricação (MINDLIN, 1999).

A arquitetura moderna introduziu conceitos que valorizavam a cultura e o modo de vida nacionais, inclusive na elaboração de um paisagismo de alta qualidade, com espécies brasileiras. Os edifícios citados anteriormente, em sua maioria, são exemplares da arquitetura moderna e foram construídos com agilidade, de maneira racional, utilizando materiais pré-moldados e valorizando o uso dos espaços. $\mathrm{Na}$ arquitetura moderna desse período existia uma forte tendência racionalista que negava as tradições clássicas em prol de um novo modo de vida, possível através do desenvolvimento industrial crescente; e pelo funcionalismo baseado nas idéias da escola alemã Bauhaus, economizando no uso solo e dos materiais de construção, buscando trabalhar sempre com as tecnologias mais avançadas existentes no momento da criação, e na visão da forma como derivação de um método ou cálculo. Posteriormente, o racionalismo arquitetônico encontrou barreiras dentro de sua própria doutrina, já que a realidade humana, em sua complexidade, não se resume à aplicação de métodos e cálculo exatos (MONTANER, 2001). No entanto, a arquitetura moderna brasileira soube fazer bom uso das idéias preconizadas no funcionalismo racionalista, e trouxe para sua produção os elementos que a colocaram dentro do cenário mundial da arquitetura modernista.

Dentro de uma idéia de sustentabilidade ancorada em três aspectos principais: crescimento econômico, bem estar social e preservação ambiental, pode-se afirmar que a arquitetura praticada pelo mercado imobiliário, nas produções das décadas de 1950, 1960 e 1970 foi uma arquitetura sustentável, eficiente no uso dos recursos naturais, principalmente no uso da energia; justa com os valores sociais e com o bem estar humano; e lucrativa do ponto de vista econômico, já que naquele momento a atividade de construção era um investimento atraente para a reprodução do capital. 
Segundo o relatório "Buildins and Climate Change", publicado pelo UNEP - United Nations Environment Progremme em 2007, os edifícios comerciais e residenciais construídos no Brasil, nas décadas de 1960 e 1970 tendem a ser mais eficientes em termos de consumo de energia, quando comparados aos novos edifícios, pois eles exploravam oportunidades de soluções passivas, bem como inércia térmica e utilização de brise-soleil, diminuindo a necessidade por sistemas de climatização. Atualmente, com a realização de uma arquitetura baseada em modelos importados, com fachadas completamente envidraçadas, as construções no Brasil tendem a aquecer durante o verão, demandando mais energia para a climatização dos ambientes.

Conforme esclarece Fonseca (2006), a questão da queda da qualidade na arquitetura, a partir do final da década de 1970, está ligada à alteração da função do arquiteto dentro do processo de construção, uma vez que o projeto de arquitetura e complementares não se viabiliza dentro da própria estrutura da incorporadora, sendo contratados no mercado, e tendo como condição sempre a minimização dos custos. Outro fator que levou à perda da qualidade das construções foi a diminuição da presença do Estado como promotor de edifícios e produtor de padrões de referência. Durante os anos 1940 a 1970 o Estado se fez presente como investidor e produtor de arquitetura, com muitos exemplares notáveis.

A criação do BNH - Banco Nacional da Habitação, em 1964, gerou uma explosão da demanda, que fez com que as empresas não precisassem mais atrair os compradores com bons projetos. O aumento quantitativo de habitações conduziu a qualidade média das edificações para patamares cada vez mais baixos. A competitividade se fez através da diminuição das áreas das unidades, visando a lucratividade máxima do empreendimento. Em oposição a ocupação predominante no alinhamento dos terrenos que caracterizavam os edifícios construídos nas décadas de 50 e 60, a partir de 1970, a implantação se faz a partir do recuo de frente da rua, dos recuos laterais de 3 metros, das faixas $A 1$ e $A 2$, e das determinações resultantes da necessidade de recuos de fundo do lote. A exigência complementar da existência de um círculo com diâmetro de 16 metros completa o quadro determinante dessa 
implantação, que ao abandonar possíveis propostas de inserção urbana, deposita suas intenções numa monótona variação de arranjos de plantas (FONSECA, 2006).

A busca pela lucratividade máxima, com o mínimo gasto levou as incorporadoras a repetirem os modelos que se tornaram referência no mercado, como uma espécie de carimbo que se aplica a qualquer terreno, desde que respeitando os limites da lei, sem estudos mais aprofundados de implantação e de entorno. Como resultado dessa repetição, o profissional de arquitetura deixou de ser necessário durante as etapas de planejamento do edifício e passou a ser solicitado apenas para o arranjo interno das plantas, encaixando as unidades dentro dos limites da laje préestabelecida e para o desenho das fachadas. A queda da qualidade deve-se, então, também ao fato de os arquitetos serem retirados do processo de decisão do projeto de arquitetura e passarem a atuar conforme mandam as estratégias de marketing da incorporadora, direcionando seu foco na busca atração do cliente. 


\subsection{O Mercado Imobiliário Brasileiro Após a Virada do Século (XX-XXI)}

Com a virada do século $X X$ para o século $X X I$, as formas de produção habitacional evoluíram no sentido de ampliar a acumulação de capital. O crescimento da economia, aliado a estratégias implantadas pelo governo e setor privado, juntamente com o aumento dos investimentos internacionais, impulsionaram o mercado imobiliário e, novamente, o setor de construção retomou um ritmo de crescimento dinâmico e acelerado, que caracterizou um novo "boom imobiliário" residencial em São Paulo. Porém, essa recente explosão imobiliária não se limita às classes mais altas. O aumento do crédito imobiliário, a facilidade para aquisição de financiamento a longos prazos e a enorme carência de moradia para as classes mais baixas, levaram o mercado a atender parte dessa demanda, que agora se mostra interessante.

A construção de moradias para a baixa renda, que nunca foi atrativa para o mercado imobiliário, passou a ser, a partir de 2004, uma atividade lucrativa. Entretanto, como adverte Edney Cielici Dias em artigo para a revista Conjuntura da Construção (março, 2008), quando se fala nesta faixa de renda, está-se referindo a um rendimento familiar mensal entre quatro e dez salários mínimos ao mês. Isso significa que a faixa de renda familiar onde o ganho é de até três salários mínimos ao mês, onde se concentram $79 \%$ do déficit habitacional brasileiro, continua fora desse mercado (SINDUSCON, 2008). Ainda assim, o mercado para a baixa renda, cujas unidades habitacionais custam entre $R \$ 40 \mathrm{mil}$ e $R \$ 100 \mathrm{mil}$, se mostra importante, mas contribui apenas para a diminuição de uma pequena parte do déficit, como mostram os gráficos 3.1 e 3.2, nos quais é apresentada a participação das faixas de renda, na composição do déficit habitacional brasileiro. 
Gráfico 3.1 - Déficit Habitacional por faixa de renda

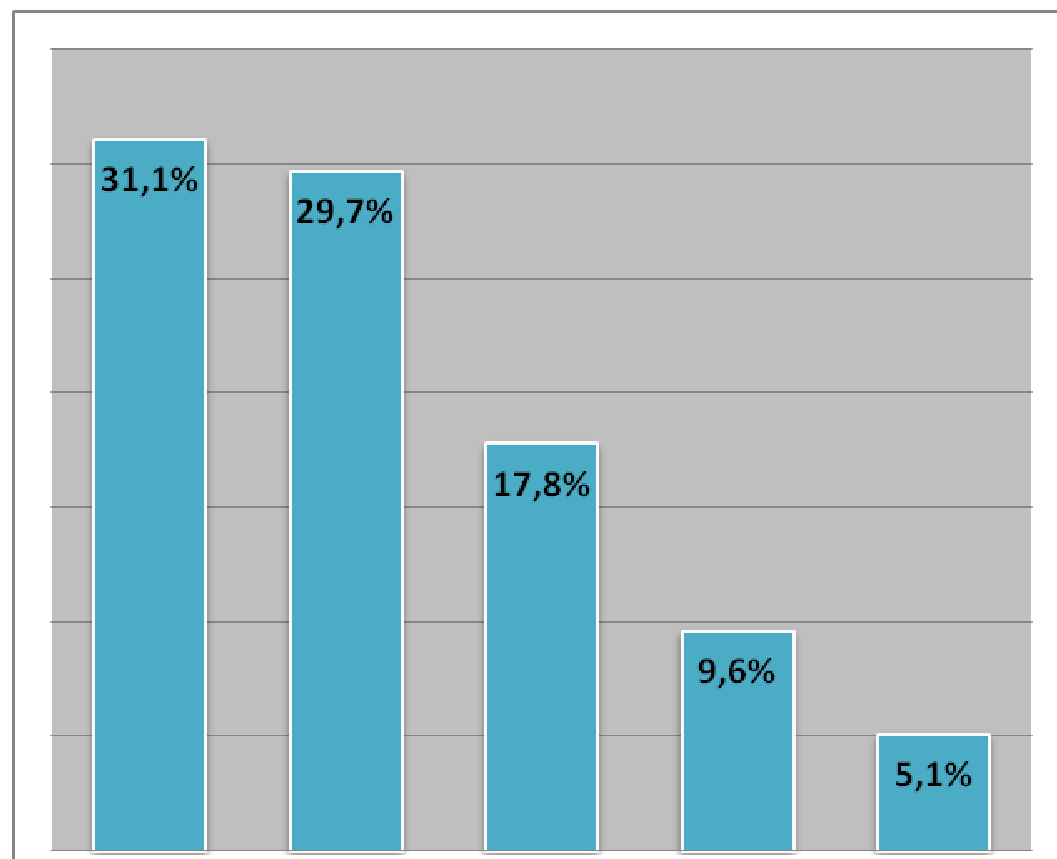

até $1 \mathrm{s.m}$. até $2 \mathrm{~s} . \mathrm{m}$. até $3 \mathrm{~s} . \mathrm{m}$. até $4 \mathrm{~s} . \mathrm{m}$. até $5 \mathrm{~s} . \mathrm{m}$. Fonte: FGV, 2008.

Gráfico 3.2 - Déficit Habitacional Acumulado por faixa de renda

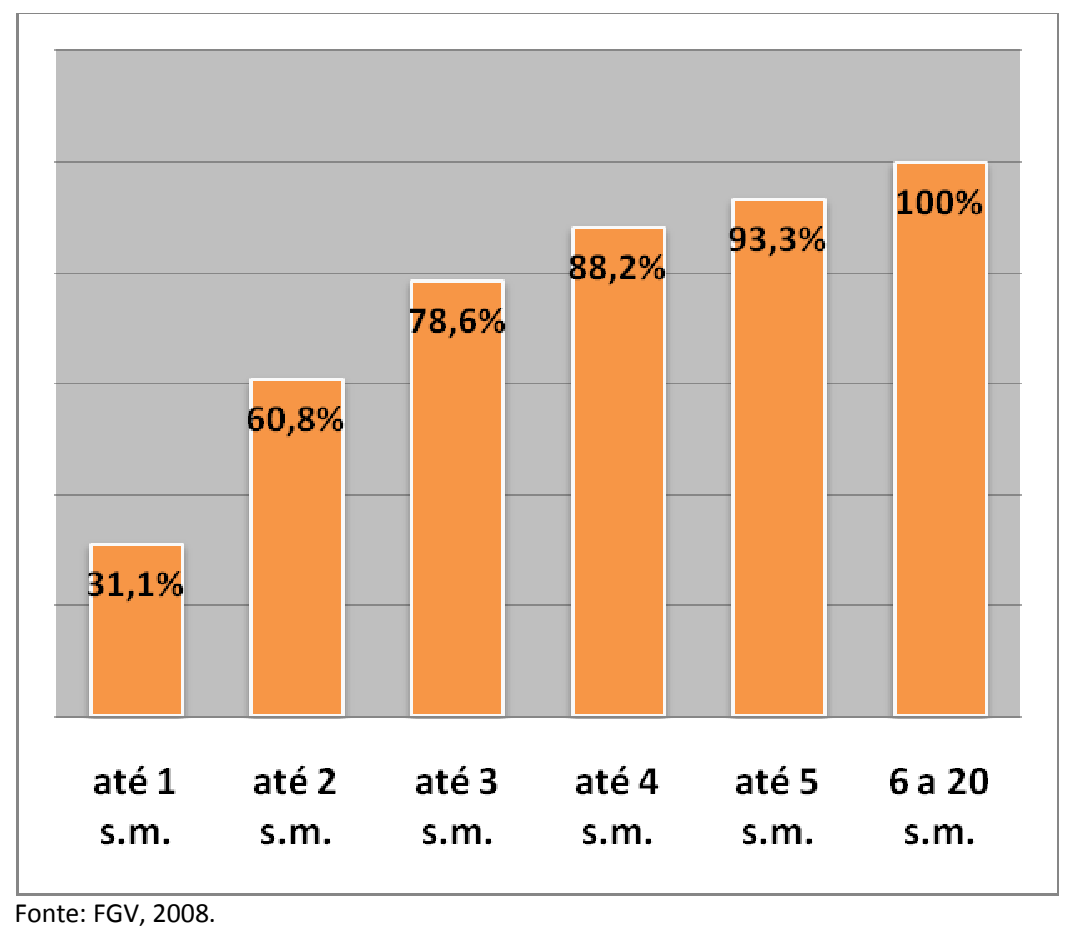

Fonte: FGV, 2008. 
Segundo estudo feito pela FGV - Fundação Getúlio Vargas, no período entre 2005 e 2007 o déficit habitacional absoluto diminuiu em 670 mil unidades habitacionais, proporcionando uma queda de $8 \%$ no número de famílias que dividiam o mesmo teto com outras. Isso pode ser observado no gráfico 3.3. O déficit habitacional está dividido em dois grandes componentes: coabitação (famílias dividindo, voluntariamente ou não, o mesmo teto) e inadequação (deficiência da moradia). Se, por um lado, o índice de coabitação caiu significativamente, o déficit por inadequação aumentou em 28 mil unidades. Isso significa que o número de lares inadequados aumentou em 0,8\%, entre 2005 e 2007 (DIAS; GARCIA, 2008).

Os domicílios que compõem o déficit por inadequação são classificados como "aglomerados urbanos sem total infra-estrutura", entre eles, as favelas. Segundo Dias e Garcia, São Paulo e Rio de Janeiro concentram mais da metade das moradias nessas condições.

\section{Gráfico 3.3 - Evolução do déficit habitacional absoluto (2005-2007)}

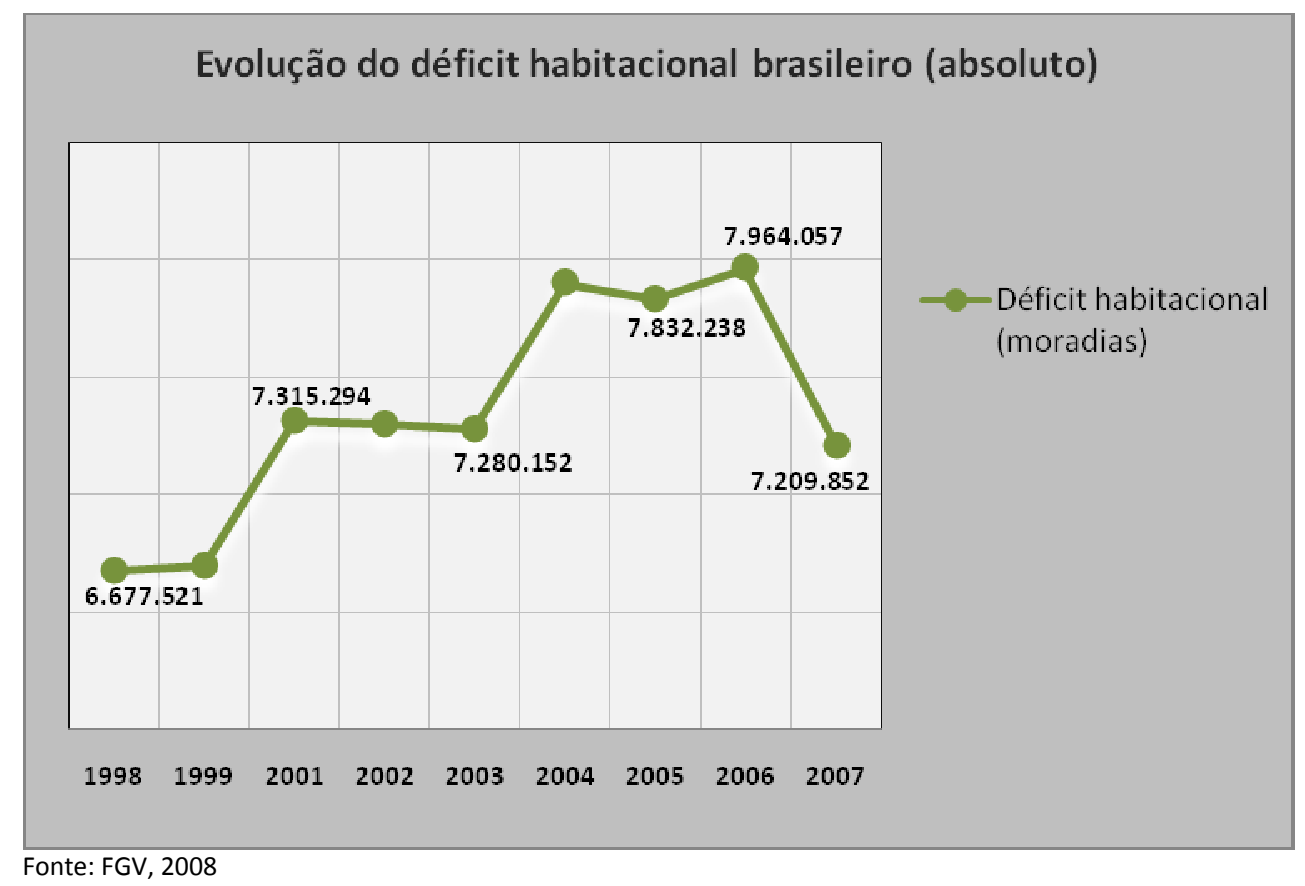

Resultados de pesquisas recentes mostram um crescimento significativo no número de unidades de habitação, construídas entre 2005 e 2007, e apontam para um 
aumento desse crescimento nos próximos anos, com o mercado imobiliário privado atendendo à parcela da população com renda acima de cinco salários mínimos, mas, principalmente com o lançamento do PlanHab - Plano Nacional da Habitação, apresentado pelo governo federal no início de 2009, com o objetivo de injetar recursos para a construção de moradias para as famílias de renda até cinco salários mínimos. Pretende-se, com o PlanHab, diminuir o déficit habitacional brasileiro em 50\%, com a construção de 4 milhões de novas unidades habitacionais para as classes mais baixas. A primeira meta do programa é realizar a construção de 1 milhão de moradias até o ano de 2011. Seriam investidos, nesse período, $\mathrm{R} \$ 39,5$ bilhões. Enquanto os resultados do programa começam a aparecer em números, como mostra a tabela 3.1, a produtividade do mercado imobiliário privado se mantém em ritmo acelerado e é apontada como o principal fator do crescimento do PIB nos últimos anos.

Tabela 3.1 - Redução do déficit habitacional, por estado, em um ano de PlanHab

\begin{tabular}{|l|c|c|}
\hline \multicolumn{1}{|c|}{ UF } & Déficit em 2007 & Após 1 ano \\
\hline São Paulo & 1.358 .806 & 1.264 .573 \\
\hline Rio de Janeiro & 665.058 & 618.937 \\
\hline Pará & 547.109 & 509.167 \\
\hline Minas Gerais & 542.778 & 505.137 \\
\hline Bahia & 537.494 & 500.219 \\
\hline Maranhão & 533.887 & 496.862 \\
\hline Ceará & 422.756 & 393.438 \\
\hline Rio Grande do Sul & 355.131 & 330.503 \\
\hline Pernambuco & 312.987 & 291.281 \\
\hline Amazonas & 240.427 & 223.753 \\
\hline Paraná & 238.442 & 221.906 \\
\hline Piauí & 187.150 & 174.171 \\
\hline Paraíba & 167.346 & 155.741 \\
\hline Goiás & 148.398 & 138.107 \\
\hline Santa Catarina & 132.421 & 123.238 \\
\hline Alagoas & 115.827 & 107.794 \\
\hline Rio Grande do Norte & 111.786 & 104.034 \\
\hline Espírito Santo & 100.851 & 93.857 \\
\hline Distrito Federal & 73.756 & 68.641 \\
\hline Mato Grosso & 71.569 & 66.606 \\
\hline Sergipe & 69.867 & 65.022 \\
\hline & & \\
\hline
\end{tabular}




\begin{tabular}{|l|c|c|}
\hline Tocantins & 68.283 & 63.548 \\
\hline Mato Grosso do Sul & 66.360 & 61.758 \\
\hline Rondônia & 57.004 & 53.051 \\
\hline Acre & 38.351 & 35.691 \\
\hline Amapá & 30.854 & 28.714 \\
\hline Roraima & 15.154 & 14.103 \\
\hline Brasil & $\mathbf{7 . 2 0 9 . 8 5 2}$ & $\mathbf{6 . 7 0 9 . 8 5 2}$ \\
\hline
\end{tabular}

Fonte: Sinduscon, 2009

Para que a qualidade da vida urbana melhore, mais do que construir moradias para a população pobre, deve-se melhorar o IDH - Índice de Desenvolvimento Habitacional do país, que calcula o acesso à infra-estrutura de água e esgoto. Embora o IDH tenha mantido um crescimento regular nas duas últimas décadas, conforme mostra o gráfico 3.4, o aumento do déficit habitacional por inadequação sugere que cresceu o número de domicílios improvisados, sem acesso à infra-estrutura. A população urbana pobre continua crescendo mais do que a população consolidada nos anéis centrais da cidade, e ocupando áreas distantes e menos valorizadas, aonde a infra-estrutura ainda não chegou.

\section{Gráfico 3.4 - Índice de Desenvolvimento Habitacional Brasileiro}

\begin{tabular}{|r|lcc|}
\hline 0,9 & IDH-Hab* & $\mathbf{0 , 8 2 6}$ & $\mathbf{0 , 8 8 1}$ \\
0,85 & & & \\
0,8 & $\mathbf{0 , 7 5 3}$ & & \\
0,75 & & & \\
0,7 & 2001 & 2007 \\
0,65 & & & \\
1993 & & \\
& & & \\
\end{tabular}

De acordo com os dados disponibilizados pela FVG, o Índice de Desenvolvimento Habitacional evoluiu de forma generalizada, num ritmo regular e constante, ao longo dos últimos quinze anos, em todos os estados brasileiros. Esse 
dado reafirma o fato de que o mercado imobiliário mantém seus investimentos nas áreas centrais da cidade, onde já está consolidada a rede de infra-estrutura, não colaborando, portanto, para a melhora do IDH brasileiro.

Entre os anos de 2004 e 2007, o rápido crescimento do setor de construção pode ser observado nos números dos lançamentos imobiliários. Nesse período o PIB do setor acumulou um crescimento de $22,4 \%$, recuperando-se das quedas dos anos anteriores. Algumas medidas tomadas pelo governo, entre elas a decisão de pressionar os bancos a elevarem o percentual de recursos da poupança, voltados ao financiamento habitacional, a agilização da análise e a facilitação da concessão de crédito pela Caixa Econômica Federal, aumentaram o número de unidades habitacionais financiadas com recursos da poupança de 53,8 mil em 2005, para 195,9 mil em 2007 (Sinduscon, 2008), com a maior parte dos financiamentos voltados para a classe média baixa, em todo o país. Em São Paulo, os lançamentos de unidades habitacionais dobraram entre 2004 e 2007 (gráfico 3.5). O número de empregos formais no setor aumentou em 37\%. Cresceu, também, a renda dos trabalhadores, como mostram os gráficos 3.6 e 3.7. Se considerarmos o total de trabalhadores (formais e informais), o crescimento do emprego foi de $8,4 \%$, somando mais de 6 milhões de trabalhadores.

Gráfico 3.5 - Lançamento de unidades habitacionais em São Paulo nos últimos dez anos

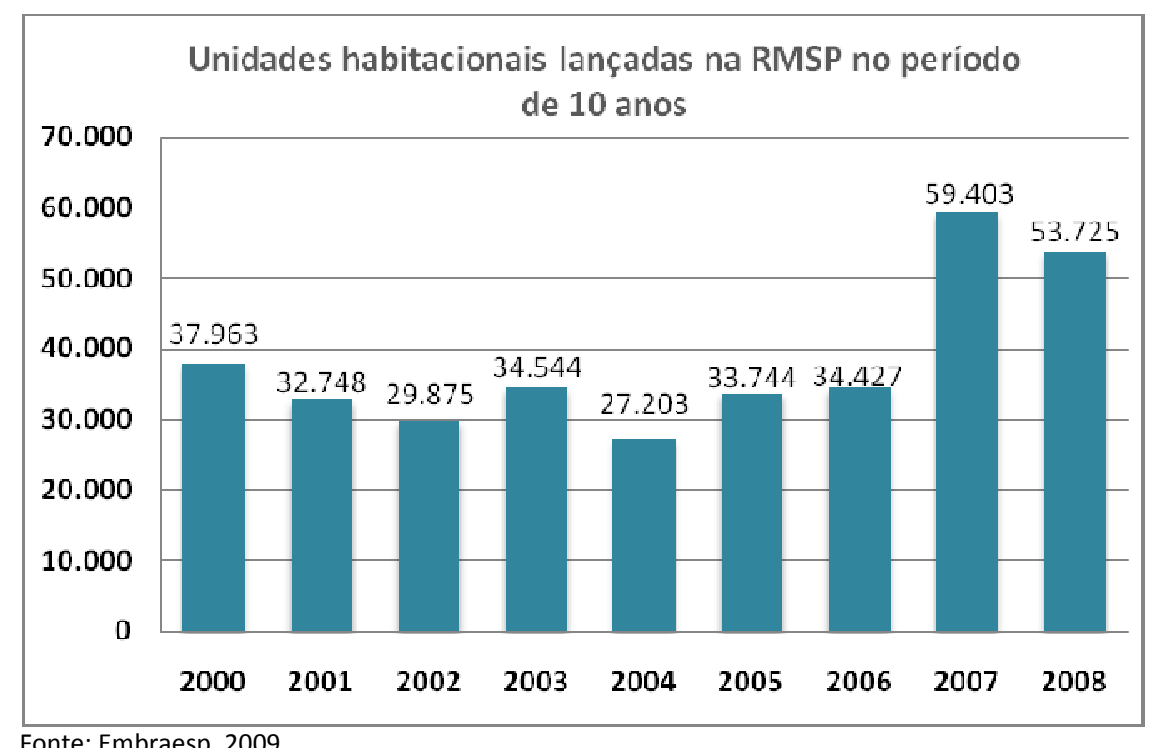

Fonte: Embraesp, 2009 
Gráfico 3.6 - Trabalhadores com carteira no setor de construção

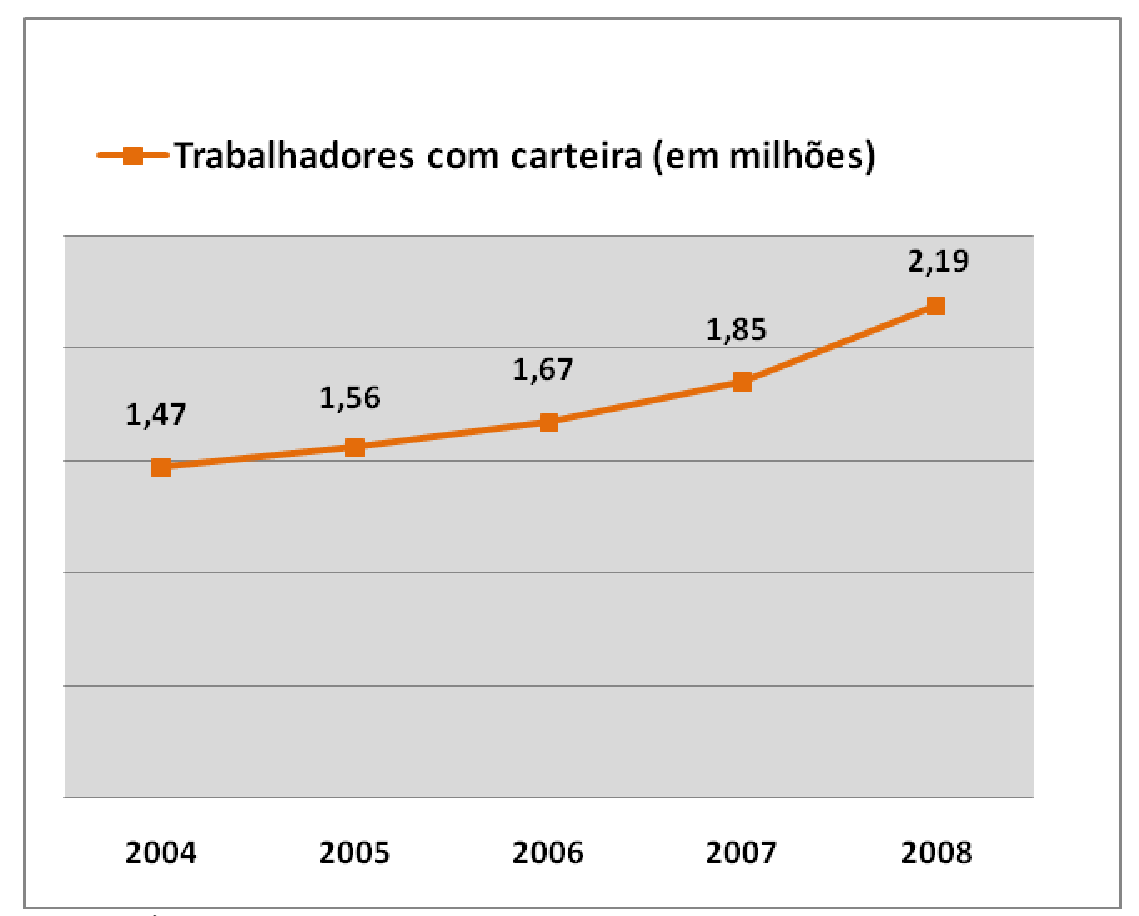

Fonte: Sinduscon, 2008

\section{Gráfico 3.7 - Renda média na construção (2005-2007)}

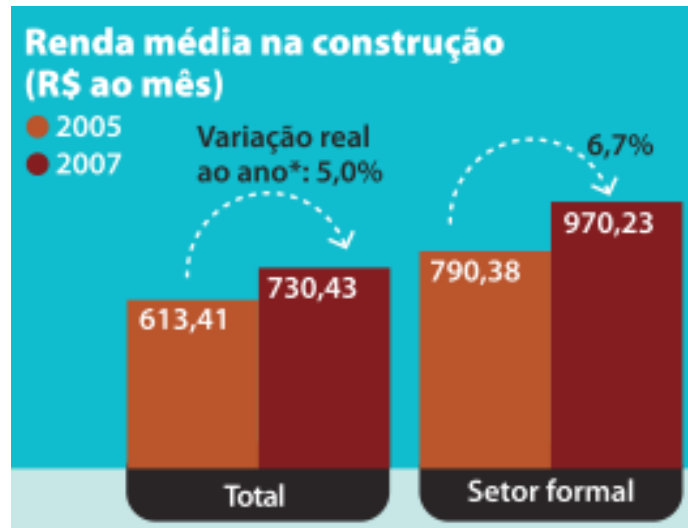

Fonte: Sinduscon, 2008

Esse quadro animador causou uma onda de otimismo no mercado imobiliário, levando algumas empresas a abrirem capital na Bolsa, para captação de investimentos internacionais. A partir de 2005, vinte e quatro construtoras e incorporadoras captaram mais de $\mathrm{R} \$ 19$ bilhões em investimentos internacionais no mercado aberto. Com a chegada da crise econômica mundial, em 2008, os recursos internacionais 
diminuíram significativamente, não afetando, porém, a tendência crescente do mercado imobiliário brasileiro. Embora esse crescimento tenha se estabilizado e ficado aquém das expectativas do setor, no ano de 2008, o mercado continuou crescendo em 2009.

É importante citar os fatos que marcaram a evolução da política habitacional no Brasil, a partir da década de 1990 (DIAS, 2009):

1997 - A lei 9.514 instituiu o Sistema de Financiamento Imobiliário (SFI), que estabeleceu uma conexão direta entre o mercado de capitais e o negócio imobiliário. Foram criadas as companhias securitizadoras de créditos imobiliários, instituídos os Certificados de Recebíveis Imobiliários (CRIs) e introduzida a alienação fiduciária de bens imóveis, que conferiu mais rapidez nas execuções de garantias.

2001 - A lei 10.257 (Estatuto da Cidade) regulamentou o capítulo de política urbana (artigos 182 e 183) da Constituição Federal. Definiu a função social da cidade e da propriedade urbana e delegou tarefa para os municípios, oferecendo a estes um conjunto de instrumentos de intervenção sobre seus territórios.

2003 - A criação do Ministério das Cidades representou um marco institucional na rearticulação da política habitacional e de infra-estrutura urbana.

2003 e 2004 - O Programa de Subsídio à Habitação de Interesse Social (PSH), regulamentado pela lei $\mathrm{n}$ - 10.998 e o decreto $\mathrm{n}$ - 5.247, passou a utilizar recursos orçamentários para subsidiar operações de financiamento e parcelamento habitacionais de interesse social.

2004 - A definição do patrimônio de afetação, com a lei 10.931, visou proteger o adquirente de imóveis em caso de insolvência ou negligência do incorporador, evitando-se a perda dos recursos pagos no período de construção. 
2004 - A lei 10.931 também possibilitou a continuidade do pagamento do valor incontroverso das obrigações decorrentes de operações imobiliárias. Antes da lei, ao questionar judicialmente o valor das prestações, o mutuário deixava de pagar ao credor todo o valor da prestação, depositando-a integralmente em juízo. Depois da lei, o mutuário deve discriminar na petição inicial as parcelas das obrigações com as quais não concorda e as que não são objeto de questionamento.

2005 - O Sistema Nacional de Habitação de Interesse Social e o Fundo Nacional de Habitação de Interesse Social (SNHIS e FNHIS) foram criados pela lei federal no 11.124 com o objetivo de integrar todos os programas destinados à habitação de interesse social de todas as esferas de governo.

2008 - O Plano Nacional da Habitação (PlanHab), consolidado em 2008, estabelece as diretrizes da política habitacional. Trata-se de um documento amplo, que abordou a integração com política urbana e trouxe inovações com relação à política voltada às famílias de baixa renda.

Como já mencionado em inúmeras pesquisas, o setor imobiliário cresce mais do que o país, em termos econômicos. Esse dado sugere que o aumento do número de lançamentos e aquisição de imóveis não significam necessariamente um aumento da capacidade de consumo da população, em função do aumento da renda, mas sim, a possibilidade de dinheiro fácil oferecido pelos bancos. Um novo problema pode estar se formando, a exemplo do que aconteceu nos Estados Unidos: uma grande quantidade de financiamentos significa um grande risco, já que durante o longo prazo de pagamento, que pode chegar a trinta anos, qualquer impossibilidade de pagar a parcela negociada pode gerar uma onda de inadimplência e arruinar muitos negócios. Além disso, já foi mencionado que o mercado imobiliário se propõe a atender a demanda de consumidores que possuem renda acima de quatro salários mínimos. Os outros $78,6 \%$ da população carente de moradia deverão ser atendidos pelos programas de acesso à habitação, propostos pelo governo. 
Do ponto de vista urbanístico, o mercado imobiliário atual não colabora para enfrentamento de problemas infra-estruturais da cidade. A atividade de construção, na maioria dos casos, tenta tirar partido dessa distribuição desigual de serviços básicos, de modo que os empreendedores imobiliários, em vez de buscar a implantação efetiva de uma política que leve à ocupação racional da terra, em proporção com a capacidade de infra-estrutura de serviços urbanos instalados, pressiona o poder público para que deixe construir cada vez mais nos terrenos centrais, por meio de alterações nas leis de zoneamento, que definem o potencial de construção dos terrenos (MALTA CAMPOS, 1989). Dentro da condição de capital privado, não cabe ao mercado imobiliário prover as necessidades básicas da população, porém, como ele é o principal transformador do espaço urbano, deve garantir que os impactos gerados pelos empreendimentos sejam minimamente sentidos pela população e acompanhados de um cuidado com seu entorno. Os avanços recentes do mercado imobiliário, como vimos, não elevam as condições de moradia a níveis melhores, não só porque esta não é a pretensão do capital privado, mas, principalmente, porque o capital privado tem o poder de direcionar os investimentos públicos para o atendimento dos seus interesses, não deixando brechas para a implantação de estratégias para o desenvolvimento urbano homogêneo do território da cidade. 


\subsection{O Uso das Certificações Ambientais}

Existem, atualmente, em alguns países, sistemas criados para avaliar a eficiência dos edifícios. Nos países em acelerado processo de desenvolvimento tem-se estudado uma forma de adaptação desses sistemas e de criação de uma ferramenta própria para classificar os edifícios e avaliá-los com enfoque na sustentabilidade. No entanto, a falta de um sistema nacional para avaliação de edifícios tem levado muitas empresas a adotar os sistemas internacionais de certificação (Figura 3.11) para avaliar o desempenho de empreendimentos nacionais.

Figura 3.11. Sistemas de certificação existentes no mundo

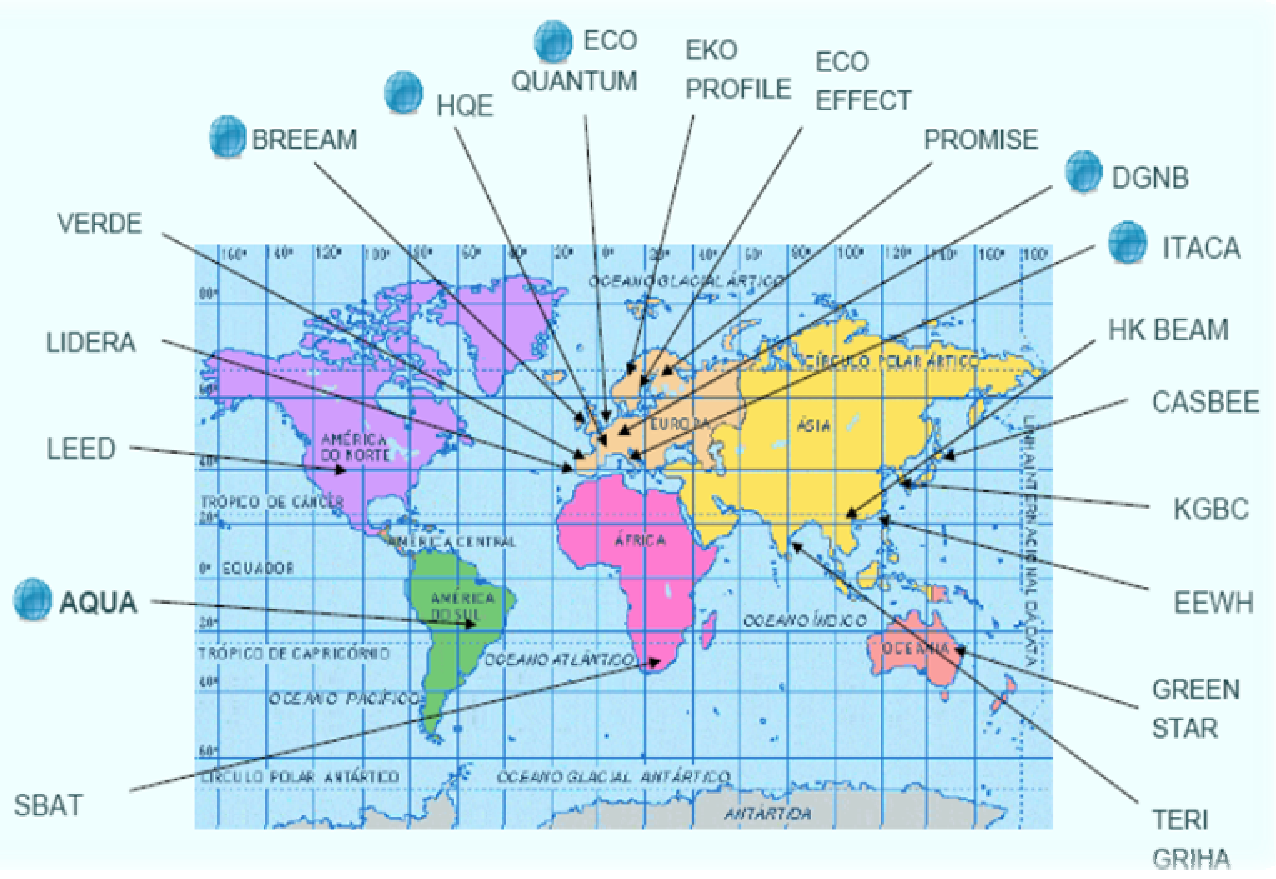

Fonte: WWW.geoconstruction.com 
No Brasil, recentemente foi elaborado um processo de avaliação ambiental de edifícios, o AQUA - Alta Qualidade Ambiental, baseado na versão francesa HQE Haute Qualité Environnementale, sistema que mais se adequou aos padrões brasileiros de construção. O AQUA foi elaborado pela Fundação Vanzolini em cooperação com a CERQUAL - Certification Qualité Logement para avaliar edifícios construídos no Brasil, considerando as características sociais, econômicas e ambientais do país. Em 2008 foram lançados os manuais para edifícios comerciais e institucionais, e no final de 2009 foi lançado o manual para a construção de edifícios residenciais.

A certificação mais utilizada no Brasil, atualmente, é a norte-americana LEED Leadership in Energy and Environmental Design, um sistema de pontuação, cuja avaliação pode conceder ao edifício um dos níveis de certificação: certificado, prata, ouro ou platina. Até o final de 2009, cinqüenta e quatro edifícios já foram certificados ou pré-certificados pelo LEED e são considerados eficientes pelo Green Building Council, órgão responsável pela elaboração do sistema. Esses edifícios recebem um "selo verde" que permite que ele seja colocado no mercado com a garantia de uma comprovação de sustentabilidade. A avaliação de edifícios construídos no Brasil, mas certificados por sistemas internacionais tem sido fortemente contestada, já que, além das certificações internacionais não se adequarem à realidade ambiental brasileira, seu processo de avaliação é, na maioria dos casos, pouco abrangente, deixando ausentes aspectos sociais e econômicos locais, o que significa que um mesmo edifício pode ser considerado sustentável, mesmo que seja projetado para localizações com características diferentes, desde que atinja a pontuação mínima do sistema.

O sistema LEED enfoca, principalmente, questões ligadas à energia, principal problema para os países que utilizam a queima de carvão como matriz energética. Para o Brasil, um país cuja fonte de energia vem das usinas hidrelétricas, outros problemas se mostram mais urgentes, como o desmatamento de florestas e a poluição dos recursos hídricos. O LEED não garante, portanto, que um edifício brasileiro seja mais sustentável do que outros não certificados. Inúmeros profissionais questionam 
inclusive, o uso do termo "sustentabilidade", o qual pode passar uma idéia distorcida da real eficiência de um edifício, pois pode dar a falsa impressão de "auto-suficiência".

A seguir, são apresentados os sistemas internacionais de certificação de edifícios utilizados com mais freqüência: BREEAM (Inglaterra), LEED (Estados Unidos), CASBEE (Japão) e HQE (França). 


\section{LEED - Leadership in Energy and Environmental Design}

Lançado em 1999, o sistema norte-americano foi criado pelo Green Building Council para certificar edifícios comerciais. Hoje, esse sistema possui versões para certificação edifícios residenciais multifamiliares e partes específicas de um edifício. Sua estrutura simplificada de avaliação gera críticas em torno do quanto o sistema colabora não somente para o desempenho ambiental, mas para a melhoria dos problemas sócio-ambientais da cidade. O LEED for Homes Rating System possui oito categorias de avaliação. Ao final, certifica os edifícios em quatro níveis: certificado, prata, ouro e platina. A tabela 3.2 apresenta a estrutura de avaliação do LEED for Homes.

Tabela 3.2. Estrutura de Avaliação do LEED for Homes

\begin{tabular}{|c|c|c|}
\hline Categoria & Requisitos & Pontuação \\
\hline $\begin{array}{l}\text { Inovação e } \\
\text { Processo de } \\
\text { Projeto (ID) } \\
\quad \mathbf{8 \%}\end{array}$ & $\begin{array}{l}\text { Planejamento integrado do projeto; consulta à } \\
\text { comunidade local; gestão da duração da obra; } \\
\text { inovação e características regionais }\end{array}$ & 11 \\
\hline $\begin{array}{l}\text { Localização e } \\
\text { entorno (LL) } \\
\mathbf{7 , 5 \%}\end{array}$ & $\begin{array}{l}\text { Estudo de impacto de vizinhança; localização em } \\
\text { área urbanizada; acesso à infraestrutura; uso de } \\
\text { recursos locais }\end{array}$ & 10 \\
\hline $\begin{array}{l}\text { Sustentabilidade } \\
\text { local (SS) } \\
16 \%\end{array}$ & $\begin{array}{l}\text { Controle de erosão; adequação do projeto de } \\
\text { paisagismo; redução de "ilhas de calor"; } \\
\text { maximização da permeabilidade do solo; controle } \\
\text { de contaminação do solo; alta densidade }\end{array}$ & 22 \\
\hline $\begin{array}{l}\text { Eficiência no uso } \\
\text { da água (WE) } \\
11 \%\end{array}$ & $\begin{array}{l}\text { Reciclagem e reuso de água; eficiência do sistema } \\
\text { de irrigação; controle de funcionamento de } \\
\text { dispositivos economizadores }\end{array}$ & 15 \\
\hline $\begin{array}{c}\text { Energia e } \\
\text { Atmosfera (EA) } \\
28 \%\end{array}$ & $\begin{array}{l}\text { Otimização do consumo de energia; eficiência do } \\
\text { sistema de aquecimento da água; eficiência do } \\
\text { sistema de ar condicionado; eficiência do sistema } \\
\text { de iluminação artificial }\end{array}$ & 38 \\
\hline $\begin{array}{c}\text { Materiais e } \\
\text { Recursos (MR) } \\
12 \%\end{array}$ & $\begin{array}{l}\text { Desempenho da fachada; utilização de produtos } \\
\text { certificados; planejamento de coleta seletiva de } \\
\text { lixo }\end{array}$ & 16 \\
\hline $\begin{array}{c}\text { Qualidade } \\
\text { Ambiental } \\
\text { Interna (EQ) } \\
15,5 \%\end{array}$ & $\begin{array}{l}\text { Ventilação e iluminação natural; controle de } \\
\text { umidade; distribuição do espaço; controle de } \\
\text { contaminação; controle de poluição da garagem }\end{array}$ & 21 \\
\hline $\begin{array}{l}\text { Educação e } \\
\text { Conscientização } \\
\text { (AE) } 2 \%\end{array}$ & $\begin{array}{l}\text { Sensibilização e conscientização dos ocupantes; } \\
\text { Treinamento de agentes ligados à obra }\end{array}$ & 3 \\
\hline $100 \%$ & Total & 136 \\
\hline
\end{tabular}




\section{BREEAM - BRE Environmental Assessment Method}

O sistema inglês de avaliação BREEAM (BRE Environmental Assessment Method), criado na Inglaterra em 1990 por pesquisadores do BRE (Building Research Establishment) foi o primeiro sistema de avaliação ambiental a ser utilizado no mundo. Inicialmente elaborado para avaliar apenas edifícios comerciais, atualmente possui, também, versões para certificação de residências e edifícios residenciais e foi adaptado para o Canadá, Hong Kong, Dinamarca, Noruega, Austrália, Nova Zelândia e Estados Unidos. Tem como objetivo minimizar os impactos ambientais dos empreendimentos, tanto em fase de projeto como para os já construídos (CSILLAG, 2007). O BREEAM Multi-Residential avalia edifícios residenciais em nove categorias, conforme mostra a tabela 3.3, e classifica os edifícios em três níveis: bom, muito bom e excelente.

Tabela 3.3. Estrutura de Avaliação do BREEAM Multi-Residential

\begin{tabular}{|c|c|}
\hline $\begin{array}{l}\text { CATEGORIAS } \\
\% \text { dos pontos }\end{array}$ & REQUISITOS AVALIADOS \\
\hline $\begin{array}{c}\text { Gestão } \\
15 \%\end{array}$ & $\begin{array}{l}\text { Comissionamento; gestão adequada do canteiro de obras; controle de } \\
\text { CO2, energia, consumo de água, geração de resíduos, transporte e } \\
\text { desperdício nas atividades do canteiro; estudo do entorno e consulta à } \\
\text { comunidade local; seguimento de normas de segurança. }\end{array}$ \\
\hline $\begin{array}{l}\text { Saúde e conforto } \\
15 \%\end{array}$ & $\begin{array}{l}\text { Aspectos relacionados à iluminação e ventilação natural e artificial, } \\
\text { níveis de conforto térmico e acústico, e minimização dos riscos de } \\
\text { contaminação; flexibilidade para atividades de trabalho; espaços semi- } \\
\text { privados (contato com exterior). }\end{array}$ \\
\hline $\begin{array}{l}\text { Energia } \\
15 \%\end{array}$ & $\begin{array}{l}\text { Redução das taxas de emissão de } \mathrm{CO} 2 \text { e eficiência do sistema de } \\
\text { iluminação artificial; informação ao morador sobre etiquetagem de } \\
\text { eletrodomésticos. }\end{array}$ \\
\hline $\begin{array}{l}\text { Transporte } \\
10 \%\end{array}$ & $\begin{array}{l}\text { Acesso aos sistemas de transporte público; acesso a comércio e } \\
\text { serviços; estacionamento; áreas para pedestres e ciclistas. }\end{array}$ \\
\hline $\begin{array}{l}\text { Água } \\
5 \%\end{array}$ & $\begin{array}{l}\text { Dispositivos de redução do consumo de água; sistemas de tratamento e } \\
\text { reutilização de águas; sistema de deteç̧ão de vazamentos. }\end{array}$ \\
\hline $\begin{array}{l}\text { Materiais } \\
10 \%\end{array}$ & $\begin{array}{l}\text { Seleção de materiais certificados; Reuso de fachadas e estruturas de } \\
\text { edifícios existentes; espaços destinados a armazenamento de materiais } \\
\text { recicláveis. }\end{array}$ \\
\hline $\begin{array}{l}\text { Uso do solo } \\
\quad 15 \%\end{array}$ & $\begin{array}{l}\text { Verificação de contaminação do solo; preservação de áreas verdes; } \\
\text { renovação de áreas degradadas; conscientização de operários para a } \\
\text { preservação durante a obra; profissional especializado para análise da } \\
\text { vegetação do local do empreendimento. }\end{array}$ \\
\hline $\begin{array}{l}\text { Poluição } \\
15 \%\end{array}$ & $\begin{array}{l}\text { Evitar áreas de inundação; minimização impermeabilização do solo; } \\
\text { conformidade do sistema de iluminação externa; redução da poluição } \\
\text { da água e do ar (excluindo CO2, tratado no item Energia); utilização de } \\
\text { fontes de energia renováveis ou de baixa emissão de poluentes. }\end{array}$ \\
\hline
\end{tabular}




\section{CASBEE - Comprehensive Assessment System for Building Environmental Efficiency}

O sistema japonês CASBEE, criado em 2002, é constituído de quatro metodologias de análise: Pré-projeto, Novas construções, Edifícios existentes e Renovações. O Casbee interpreta o edifício por um espaço interno (privado) e um espaço externo (público), definido pelos limites do sítio. O sistema define dois fatores: $Q$ e L. O fator " $Q$ " avalia a qualidade e desempenho ambiental do edifício, do ponto de vista do usuário dentro do espaço privado. O fator " $L$ " refere-se a cargas ambientais do edifício e avalia o impacto no espaço público. O sistema avalia quatro aspectos: eficiência energética, eficiência no uso dos recursos naturais, ambiente local e ambiente interno. $O$ desempenho do edifício recebe notas que vão de (excelente) $A$, B+, B- a C (fraco) (CSILLAG, 2007). As tabelas 3.4 e 3.5 apresentam a estrutura de avaliação do CASBEE.

Tabela 3.4. Sistemas de avaliação que compõem o CASBEE

\begin{tabular}{|c|c|c|}
\hline $\begin{array}{l}\text { Metodologia de } \\
\text { Avaliação }\end{array}$ & Usuários & Objetivos / características \\
\hline \multicolumn{3}{|l|}{ Edifícios Novos } \\
\hline $\begin{array}{l}\text { Ferramenta de avaliação } \\
\text { pré-projeto }\end{array}$ & $\begin{array}{l}\text { Proprietários } \\
\text { Planejadores } \\
\text { Projetistas }\end{array}$ & $\begin{array}{l}\text { Identificação do contexto básico do } \\
\text { projeto, com ênfase em seleção de } \\
\text { área e impactos básicos do projeto }\end{array}$ \\
\hline $\begin{array}{l}\text { Ferramenta de projeto } \\
\text { para o ambiente }\end{array}$ & $\begin{array}{l}\text { Projetistas } \\
\text { Construtores }\end{array}$ & $\begin{array}{l}\text { Teste simples de auto-avaliação para } \\
\text { auxiliar a melhorar a eficiência } \\
\text { ambiental do edifício (BEE) durante o } \\
\text { processo de projeto }\end{array}$ \\
\hline \multicolumn{3}{|l|}{ Edifícios existentes } \\
\hline $\begin{array}{l}\text { Ferramenta de } \\
\text { certificação ambiental }\end{array}$ & $\begin{array}{c}\text { Proprietários } \\
\text { Projetistas } \\
\text { Construtores } \\
\text { Agentes imobiliários }\end{array}$ & $\begin{array}{l}\text { Classificar edifícios construídos, } \\
\text { segundo sua eficiência ambiental. } \\
\text { Determinar o valor básico de mercado } \\
\text { do edifício certificado }\end{array}$ \\
\hline $\begin{array}{l}\text { Ferramenta de avaliação } \\
\text { pós-projeto (operação e } \\
\text { renovação sustentáveis) }\end{array}$ & $\begin{array}{c}\text { Proprietários } \\
\text { Projetistas } \\
\text { Operadores / gestores }\end{array}$ & $\begin{array}{l}\text { Prover informações sobre como } \\
\text { melhorar a BEE durante a etapa de } \\
\text { operação }\end{array}$ \\
\hline
\end{tabular}

Fonte: Csillag, 2007. 
Tabela 3.5. Estrutura de Avaliação do CASBEE

\begin{tabular}{|c|c|c|c|}
\hline $\begin{array}{l}\text { Tópicos } \\
\text { Avaliados }\end{array}$ & Categorias & Pts & Classificação dos Itens \\
\hline \multirow[b]{10}{*}{$\begin{array}{l}\text { Consumo } \\
\text { de energia }\end{array}$} & $\begin{array}{l}\text { QUALIDADE AMBIENTAL } \\
\text { Q1: Ambiente interno }(0,5)\end{array}$ & & \multirow{13}{*}{ Numerador BEE } \\
\hline & Ruído e acústica & 15 & \\
\hline & Conforto térmico & 15 & \\
\hline & Iluminação & 20 & \\
\hline & Qualidade do ar & 15 & \\
\hline & Q2: Qualidade dos serviços $(0,35)$ & & \\
\hline & Serviceability (funcionalidade, aconchego) & 10 & \\
\hline & Durabilidade & 10 & \\
\hline & Flexibilidade e adaptabilidade & 15 & \\
\hline & $\begin{array}{l}\text { Q3: Ambiente externo (ao edifício) no } \\
\text { terreno }(0,15)\end{array}$ & & \\
\hline \multirow{6}{*}{$\begin{array}{l}\text { Uso de } \\
\text { recursos } \\
\text { críticos } \\
\text { Ambiente } \\
\text { local }\end{array}$} & Manutenção e criação de ecossistemas & 5 & \\
\hline & Paisagem & 5 & \\
\hline & Características locais e culturais & 5 & \\
\hline & $\begin{array}{l}\text { CARGAS AMBIENTAIS } \\
\text { L1: Energia }(0,5)\end{array}$ & & \multirow{15}{*}{ Denominador BEE } \\
\hline & Carga térmica do edifício & 5 & \\
\hline & Uso de energia natural & 10 & \\
\hline \multirow{12}{*}{$\begin{array}{l}\text { Ambiente } \\
\text { interno }\end{array}$} & Eficiência dos sistemas prediais & 5 & \\
\hline & Operação eficiente & 10 & \\
\hline & L2: Recursos e materiais $(0,3)$ & & \\
\hline & Água & 10 & \\
\hline & Eco-materiais & 30 & \\
\hline & L3: Ambiente fora do terreno $(0,2)$ & & \\
\hline & Poluição do ar & 5 & \\
\hline & Ruídos e odores & 10 & \\
\hline & Acesso à ventilação & 5 & \\
\hline & Acesso à iluminação & 5 & \\
\hline & Efeito de ilhas de calor & 5 & \\
\hline & Carga em infra-estrutura local & 5 & \\
\hline $\begin{array}{c}80 \\
\text { subitens }\end{array}$ & 18 categorias & 220 & \\
\hline
\end{tabular}




\section{HQE - Haute Qualité Environnementale}

A ferramenta HQE foi lançada na França em 1996 e avalia edifícios não residenciais. Diana Csillag, em sua pesquisa sobre certificações internacionais, observa os seguintes aspectos inovadores do HQE, em relação aos outros sistemas:

1. O estabelecimento de um perfil ambiental para o empreendimento que considera três níveis de decisão: ambiente externo; ambiente interno no que se refere ao conforto e saúde dos ocupantes; atitudes do empreendedor com relação a precauções e respeito ao ambiente.

2. A verificação, não apenas do atendimento dos índices de desempenho, mas também a avaliação das disposições e escolhas realizadas ao longo das fases de planejamento, concepção e realização.

3. A inserção das categorias de conforto e saúde dos usuários, ampliando o foco do método para além dos limites ambientais. O método ainda requer a realização de análise de custos globais de operação.

4. Permissão de propostas alternativas para metas ambientais.

O processo é registrado e auditado em três fases distintas: na fase de programa, na etapa de projeto-concepção e na etapa de implementação-execução. Após cada uma dessas auditorias, o edifício recebe um certificado que indica o perfil de desempenho da edificação (CSILLAG, 2007).

A Tabela 3.6 apresenta a organização dos domínios do sistema HQE. 
Tabela 3.6. Organização dos Domínios HQE em Metas

\begin{tabular}{|c|c|c|c|c|c|c|}
\hline \multicolumn{7}{|c|}{ DOMÍNIO: CONTROLE E IMPACTO DO AMBIENTE EXTERIOR } \\
\hline \multicolumn{3}{|c|}{$\begin{array}{l}\text { Família Eco-construção } \\
\text { Meta (cible): 1, 2, } 3\end{array}$} & \multicolumn{4}{|c|}{$\begin{array}{c}\text { Família Eco-gestão } \\
\text { Meta (cible): 4, 5, 6, } 7\end{array}$} \\
\hline Meta 1 & Meta 2 & Meta 3 & Meta 4 & Meta 5 & Meta 6 & Meta 7 \\
\hline $\begin{array}{l}\text { Relação } \\
\text { edificação } \\
\text { com } \\
\text { ambiente } \\
\text { imediato }\end{array}$ & $\begin{array}{l}\text { Escolha de } \\
\text { produtos, } \\
\text { sistema e } \\
\text { processo } \\
\text { de } \\
\text { construção }\end{array}$ & $\begin{array}{l}\text { Canteiro de } \\
\text { obras de } \\
\text { baixo } \\
\text { impacto } \\
\text { ambiental }\end{array}$ & $\begin{array}{l}\text { Gestão de } \\
\text { energia }\end{array}$ & $\begin{array}{l}\text { Gestão de } \\
\text { água }\end{array}$ & $\begin{array}{l}\text { Gestão de } \\
\text { resíduos de } \\
\text { uso }\end{array}$ & $\begin{array}{l}\text { Manutenção, } \\
\text { desempenho } \\
\text { ambiental }\end{array}$ \\
\hline \multicolumn{7}{|c|}{ DOMÍNIO: CRIAÇÃO DE UM AMBIENTE INTERIOR SATISFATÓRIO } \\
\hline \multicolumn{4}{|c|}{$\begin{array}{c}\text { Família Conforto } \\
\text { Meta (cible): } 8,9,10,11\end{array}$} & \multicolumn{3}{|c|}{$\begin{array}{l}\text { Família Saúde } \\
\text { eta (cible): 12, 13, } 14\end{array}$} \\
\hline Meta 8 & Meta 9 & Meta 10 & Meta 11 & Meta 12 & Meta 13 & Meta 14 \\
\hline $\begin{array}{l}\text { Conforto } \\
\text { Hidro- } \\
\text { térmico }\end{array}$ & $\begin{array}{l}\text { Conforto } \\
\text { acústico }\end{array}$ & $\begin{array}{l}\text { Conforto } \\
\text { visual }\end{array}$ & $\begin{array}{l}\text { Conforto } \\
\text { olfativo }\end{array}$ & $\begin{array}{l}\text { Qualidade } \\
\text { sanitária } \\
\text { dos } \\
\text { espaços }\end{array}$ & $\begin{array}{l}\text { Qualidade } \\
\text { sanitária do } \\
\text { ar }\end{array}$ & $\begin{array}{l}\text { Qualidade } \\
\text { sanitária da } \\
\text { água }\end{array}$ \\
\hline
\end{tabular}

O HQE se diferencia dos outros sistemas internacionais de certificação, principalmente, por avaliar o edifício em três ocasiões distintas: fase de programa, projeto e execução. Outra qualidade do sistema é que ele impõe que todas as categorias apresentem um bom desempenho, diferentemente dos outros sistemas, nos quais pode-se obter pontos em uma categoria e não pontuar em outras. $\mathrm{Na}$ classificação do edifício não há níveis de sustentabilidade, portanto, o edifício é ou não ambientalmente correto, respondendo a um perfil ambiental particular (CSILLAG, 2007). O fato de permitir propostas alternativas é, também, positivo e faz com que o programa não fique amarrado por metas pré-estabelecidas. 
Essa abordagem mais ampla do HQE justifica a sua escolha e pode ser conferida na Tabela 3.7, onde se faz uma comparação entre os quatro sistemas apresentados, com relação à abrangência das diferentes fases do ciclo de vida dos edifícios.

Tabela 3.7. Fases do ciclo de vida de um edifício abordadas por sistema

\begin{tabular}{|c|c|c|c|c|c|}
\hline & \multicolumn{5}{|c|}{ CICLO DE VIDA DO PROJETO } \\
\hline $\begin{array}{c}\text { Sistema de } \\
\text { Avaliação }\end{array}$ & Planejamento & Projeto & Operação & Manutenção & Demolição \\
\hline BREEAM & $\mathbf{X}$ & $\mathbf{X}$ & $\mathbf{X}$ & & $\mathbf{X}$ \\
\hline LEED & & $\mathbf{X}$ & & & $\mathbf{X}$ \\
\hline CASBEE & $\mathbf{X}$ & $\mathbf{X}$ & $\mathbf{X}$ & & $\mathbf{X}$ \\
\hline HQE & $\mathbf{X}$ & $\mathbf{X}$ & $\mathbf{X}$ & $\mathbf{X}$ & $\mathbf{X}$ \\
\hline AQUA & $\mathbf{X}$ & $\mathbf{X}$ & $\mathbf{X}$ & $\mathbf{X}$ & $\mathbf{X}$ \\
\hline
\end{tabular}




\section{AQUA - Alta Qualidade Ambiental}

A versão habitacional da certificação AQUA foi lançada no final de 2009. Em 2008 já haviam sido lançados os manuais para edifícios comerciais e institucionais. 0 AQUA é o processo de certificação para edifícios construídos no Brasil. Lançado recentemente, ele é uma adaptação do sistema francês HQE - Haute Qualité Environnementale. A escolha do sistema francês para adaptação se mostrou mais adequada ao contexto brasileiro e se deu, também, por sua forma de avaliação que foge do checklist, e é mais focado na gestão e no processo de projeto e construção do empreendimento.

Apesar de seu recente lançamento, o AQUA ainda não se tornou um sistema padrão para as empresas nacionais. A visibilidade alcançada com a aquisição do selo LEED e sua fácil aplicação levam, ainda, muitas empresas a procurarem a certificação norte-americana. Esta é, talvez, a principal barreira para que o AQUA seja difundido no setor de construção nacional.

O processo AQUA avalia quatorze categorias (conjuntos de preocupações), reunidas em quatro famílias e realiza auditorias em três fases distintas do processo de implantação do empreendimento: programa, concepção e realização.

Programa: Fase durante a qual se elabora o programa de necessidades, documento destinado aos projetistas para a concepção arquitetônica e técnica de um empreendimento.

Concepção: Fase durante a qual os projetistas, com base nas informações do programa, elaboram a concepção arquitetônica e técnica de um empreendimento.

Realização: Fase durante a qual os projetos são construídos, tendo como resultado final a construção de um empreendimento.

As categorias estão agrupadas da seguinte maneira: 
Tabela 3.8. Agrupamento das categorias do sistema AQUA - Habitacional

\begin{tabular}{|l|l|}
\hline \multicolumn{1}{|c|}{ Família } & \multicolumn{1}{c|}{ Categoria } \\
\hline \multicolumn{1}{|c|}{ Eco-construção } & 1. Relação do edifício com seu entorno \\
\hline & 2. Escolha integrada de produtos, sistemas, processos construtivos \\
\hline & 3. Canteiro de obras com baixo impacto ambiental \\
\hline Gestão & 4. Gestão da energia \\
\hline & 5. Gestão da água \\
\hline & 6. Gestão dos resíduos de uso e operação do edifício \\
\hline & 7. Manutenção - permanência do desempenho ambiental \\
\hline Conforto & 8. Conforto higrotérmico \\
\hline & 9. Conforto acústico \\
\hline & 10. Conforto visual \\
\hline & 11. Conforto olfativo \\
\hline Saúde & 12. Qualidade sanitária dos ambientes \\
\hline & 13. Qualidade sanitária do ar \\
\hline & 14. Qualidade sanitária da água \\
\hline
\end{tabular}

Fonte: Referencial Técnico de Certificação “Edifícios Habitacionais” - Processo AQUA

Ao final da avaliação, o edifício pode ser certificado como:

BOM: nível correspondendo ao desempenho mínimo aceitável para um empreendimento de alta qualidade ambiental. Isso pode corresponder à regulamentação, se esta é suficientemente exigente quanto ao desempenho de um empreendimento, ou na ausência desta, à prática corrente.

SUPERIOR: nível correspondendo ao das boas práticas.

EXCELENTE: nível calibrado em função dos desempenhos máximos constatados em empreendimentos de alta qualidade ambiental, mas se assegurando que estes possam ser atingíveis.

As categorias do processo AQUA serão melhor detalhadas no capítulo 4. 
4. ANÁLISE DA SUSTENTABILIDADE NO MERCADO IMOBILIÁRIO 
Para fazer uma análise da sustentabilidade no mercado imobiliário brasileiro, foram realizados dois estudos. Para o primeiro estudo, foi escolhido um empreendimento pré-certificado pelo sistema LEED e construído pela incorporadora e construtora EcoEsfera Empreendimentos Sustentáveis, a qual se propõe a projetar e construir edifícios residenciais multifamiliares sustentáveis.

Um segundo estudo foi realizado com quatorze empreendimentos residenciais de diversas partes do país, por meio da comparação entre os itens de sustentabilidade incorporados pelas empresas e os requisitos da certificação AQUA. Os empreendimentos foram escolhidos dentro de um contexto de sustentabilidade. Foi feita uma pesquisa sobre os lançamentos imobiliários após o ano 2000, comercializados e divulgados, por meio de campanhas de marketing, como "empreendimentos sustentáveis" e, dentro desse grupo de lançamentos, foram escolhidos os empreendimentos, de diferentes localizações e empresas, de modo que se possa ter uma idéia abrangente das ações realizadas no país.

Os dois estudos foram feitos com base no processo de certificação AQUA, escolhido por ser o processo de certificação mais adequado às características ambientais, sociais, econômicas e culturais brasileiras. O processo foi adaptado da certificação francesa HQE, a mais abrangente em termos de ciclo de vida do edifício.

A seguir, são apresentados os estudos feitos com o empreendimento Ecolife Independência, da construtora EcoEsfera, e com quatorze empreendimentos escolhidos, de diferentes construtoras, localizados em lugares diversos do país. 


\subsection{Análise do empreendimento Ecolife Independência}

Em uma primeira pesquisa percebemos a dificuldade de conseguir informações sobre o empreendimento Ecolife Independência com a construtora EcoEsfera. Para obter dados sobre as ações de sustentabilidade adotadas, entramos em contato com um consultor "online", cujo número de telefone era o único que constava no website da empresa. Ao solicitarmos o número do telefone da empresa, o consultor informou que não havia autorização para divulgar os números dos telefones ou o endereço do escritório da construtora EcoEsfera. Através de colegas profissionais da área, conseguimos o número do telefone do escritório da empresa. Ao ligarmos, informamos de que se tratava de uma pesquisa acadêmica e a atendente nos comunicou que a empresa não fornece informações, verbais ou em papel, sobre os projetos dos edifícios construídos por ela. Segundo a funcionária, todas as informações necessárias constam no website. Perguntamos, ainda, sobre a possibilidade de agendarmos uma entrevista com qualquer profissional da empresa, pessoalmente ou por via eletrônica, sobre os empreendimentos sustentáveis da Ecoesfera e, novamente, fomos informados de que não era possível.

Na segunda tentativa de contato com a empresa, ligamos para um consultor "online" e nos identificamos como possíveis compradores de uma unidade do empreendimento Ecolife Independência. Ao perguntarmos sobre as ações de sustentabilidade da empresa, o consultor nos passou uma lista com itens de sustentabilidade, a mesma que havia sido encontrada no website. Conseguimos, no entanto, agendar uma visita à obra para conferir as unidades disponíveis para venda.

Durante a visita à obra, na ausência do engenheiro responsável, fomos acompanhados pela consultora de vendas e por um assistente de engenharia. Foram feitas perguntas sobre itens presentes na lista: coleta seletiva de lixo; localização da cisterna para armazenamento de águas reaproveitáveis; porcentagem de eficiência do sistema de energia solar, e estação de tratamento de esgoto. Tanto a consultora de 
vendas, quanto o assistente da obra não souberam responder a nenhuma das perguntas.

Após a visita, fizemos uma análise da implantação e das plantas dos apartamentos, com imagens disponíveis no website da empresa. Foram analisados: a forma como os edifícios foram implantados no terreno, a distribuição dos ambientes internos e o posicionamento das aberturas com relação à ventilação, iluminação natural e incidência solar. Após a análise, fizemos uma comparação dos itens de sustentabilidade do empreendimento com os requisitos do sistema AQUA, exigidos para um empreendimento considerado BOM do ponto de vista sustentável. A certificação em nível BOM é concedida aos projetos que atendem minimamente aos requisitos do sistema.

\section{Implantação}

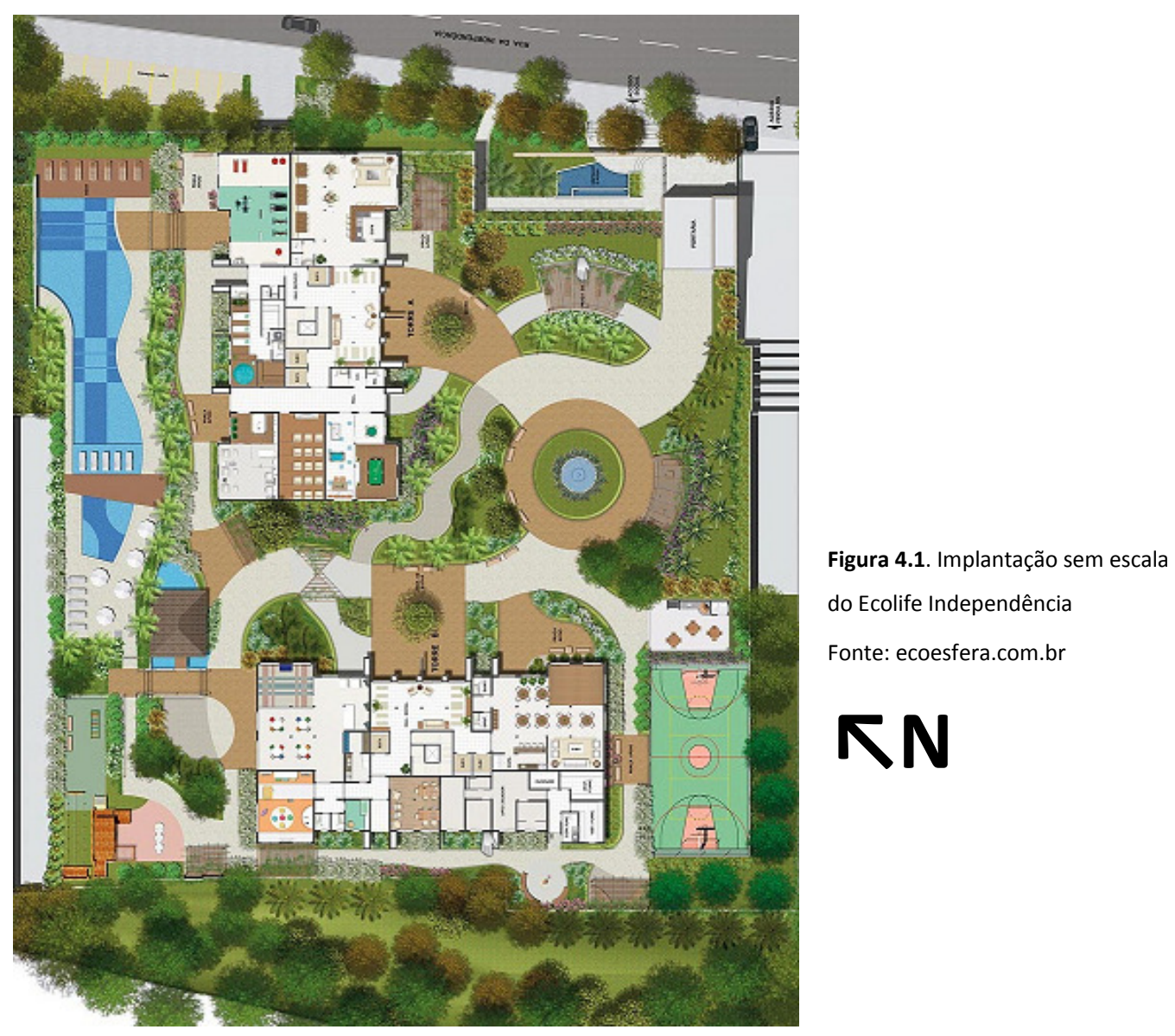


A implantação dos edifícios no terreno não levou em conta a orientação solar, o que fez com que a quadra poliesportiva ficasse direcionada longitudinalmente no sentido NE-SO, uma posição ruim para os usuários do espaço. A localização da piscina no sentido norte foi correta, porém, por estar implantada entre o muro lateral do terreno com altura de 5 metros e um dos prédios, com 16 andares, ficará sombreada a maior parte do dia. Os edifícios de apartamentos, ambos iguais, com fachadas idênticas, foram posicionados perpendicularmente entre si, resultando em fachadas mal sombreadas e outras com incidência direta do sol, já que não foram previstos elementos de sombreamento para as fachadas dos edifícios. Os espaços comuns do térreo possuem áreas pequenas em relação ao tamanho do empreendimento e o paisagismo, com desenho pobre e sem interação com os espaços comuns de lazer, não sugerem uma permanência no local.

A implantação não proporciona interação entre os edifícios e o espaço da cidade. Ao passar pela calçada o pedestre verá muros de mais de 4 metros de altura e portões igualmente altos. Mesmo entre os dois edifícios que compõem o empreendimento não há a proposição de uma aproximação. O empreendimento está voltado para o interior do terreno, negando o espaço urbano, como ocorre na maioria dos edifícios residenciais construídos a partir da década de 1980. Quanto à permeabilidade, embora haja canteiros e jardins arborizados, a permeabilidade do projeto segue o mínimo de $15 \%$ exigido por lei, em função do estacionamento, que utiliza a maior parte do subsolo.

\section{Fachadas}

O desenho das fachadas segue um padrão da empresa, simples, porém sem a sutileza encontrada na simplicidade dos projetos dos anos 50, 60 e 70. Os materiais, de baixa qualidade para áreas externas, em poucos meses terão rachaduras e manchas provocadas pela água das chuvas. Não há elementos de sombreamento e as fachadas longitudinais são iguais em todos os lados. As aberturas são determinadas pelos 


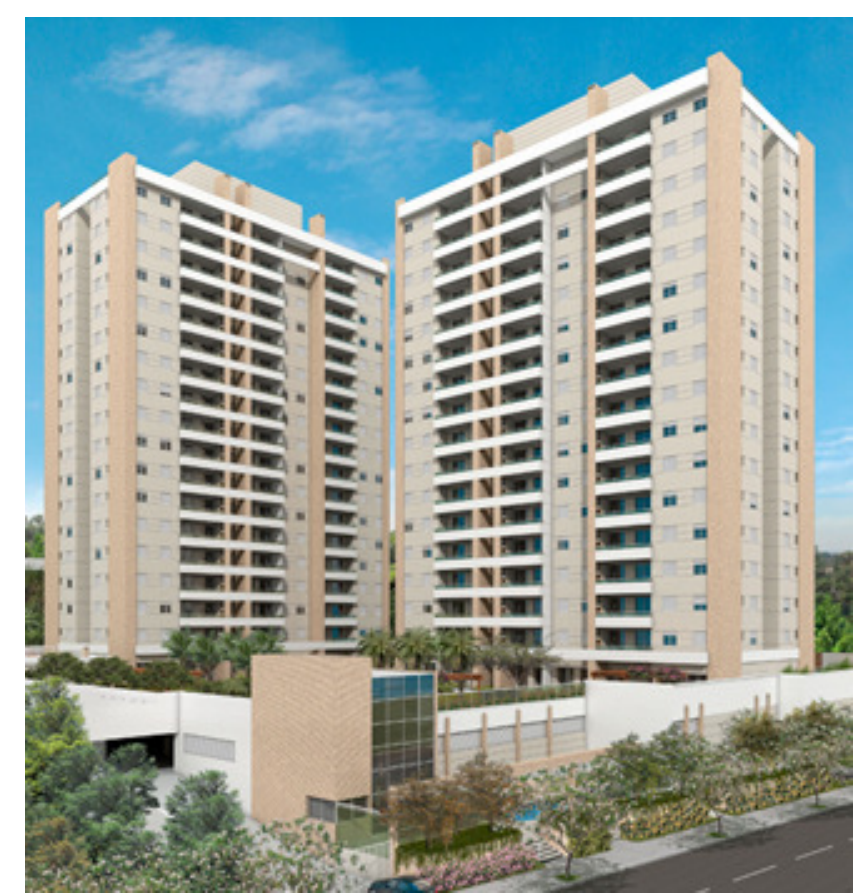

índices mínimos de ventilação e iluminação, formando um arranjo monótono de pequenos caixilhos, oferecendo à cidade mais um elemento na paisagem que não lhe acrescenta nenhum valor. A questão da falta de identidade das fachadas já foi amplamente discutida e a idéia de criar elementos que diferenciem os projetos, que os tornem únicos, levou os profissionais da arquitetura

Figura 4.2. Fachada do Ecolife Independência

Fonte: ecoesfera.com.br

a trabalharem quase como marketeiros, tratando o edifício como uma mercadoria. Oswaldo Bratke esclarece o valor das fachadas quando afirma que " $a$ fachada e a empena de uma edificação não podem e não devem simplesmente refletir a necessidade de ventilação e iluminação sugerida pela conformação das plantas dos edifícios. São espaços exteriores, quando vistos de determinada distância, e compõem um painel que está inserido na paisagem tal qual um obelisco ou um monumento. Necessitam de tratamento cuidadoso, pois que extrapolam o limite dos lotes em que estão inseridos"

\section{Unidades}

A laje "tipo" do empreendimento, com seis apartamentos de três dormitórios por andar e circulação central é um mesmo modelo implantado em outros terrenos, em outras localizações, até mesmo em outros Estados do país pela empresa EcoEsfera. O uso de um projeto "carimbo" proporciona economia financeira para o empreendedor, pois este não necessita dos serviços de um arquiteto para elaborar diferentes projetos para cada terreno em que a construtora deseja implantar um 
empreendimento. Cabe ao arquiteto, neste caso, viabilizar implantação dos edifícios no terreno, seguindo a legislação no que se refere à taxa de ocupação, coeficiente de aproveitamento, faixas de ventilação e insolação, e permeabilidade.

As plantas dos apartamentos possuem áreas pequenas para o padrão de três dormitórios. Cada dormitório possui área suficiente apenas para um único arranjo dos móveis, e os espaços para circulação são estreitos. Alguns banheiros não possuem janelas, prejudicando a circulação do ar. A cozinha também possui área pequena e sua ventilação e iluminação são feitas por intermédio da lavanderia. A área do apartamento é mal aproveitada, com corredor muito comprido e sem espaço suficiente para acomodar adequadamente uma mesa de jantar.

A incidência do sol dentro das unidades não foi estudada, podendo resultar em ambientes abafados e muito iluminados ou em ambientais frios e mal iluminados.
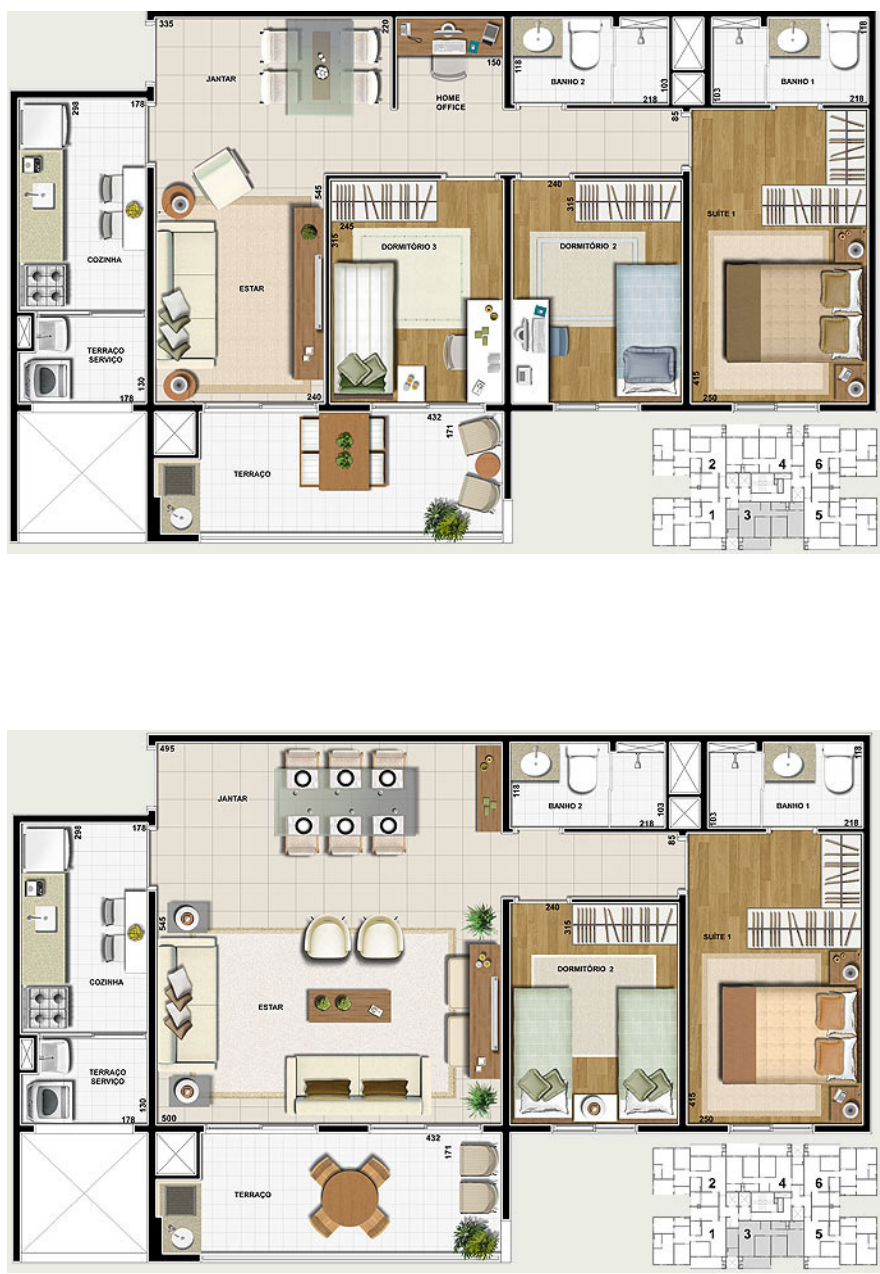

Figura 4.3. Planta da Unidade 3 (centro) do Ecolife Independência (sem escala).

Fonte: ecoesfera.com.br

Figura 4.4. Planta da Unidade 3 (centro) do Ecolife Independência com opção de 2 dormitórios (sem escala).

Fonte: ecoesfera.com.br 


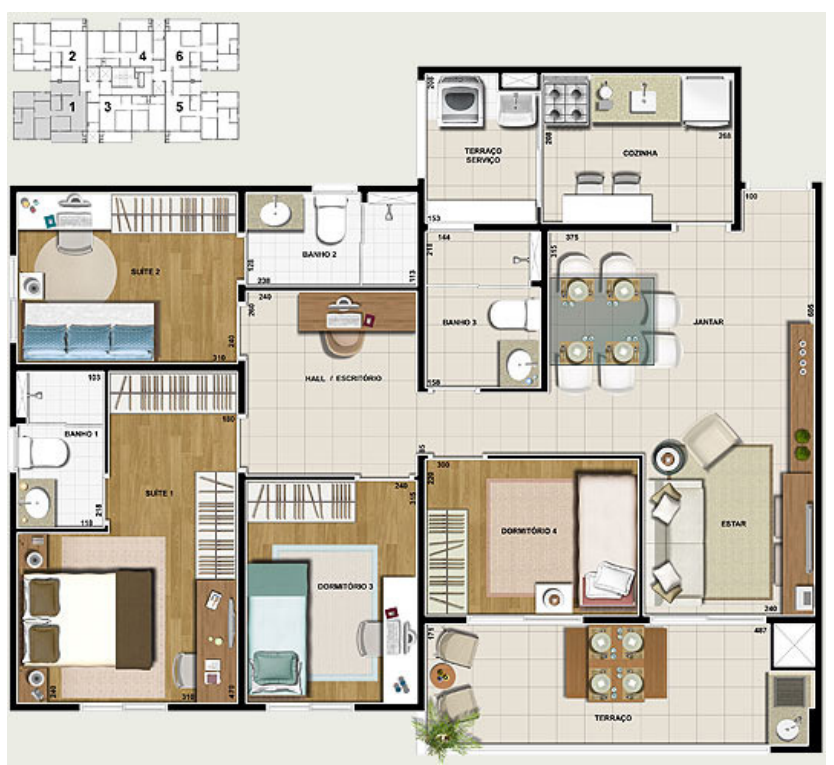

Figura 4.5. Planta da Unidade 1 (canto) do Ecolife Independência (sem escala).

Fonte: ecoesfera.com.br

\section{Itens de sustentabilidade}

As ações de sustentabilidade dos empreendimentos da incorporadora e construtora EcoEsfera são focados nos aspectos ambientais. Para justificar um projeto ecologicamente correto, foram inseridos itens e equipamentos que auxiliam na economia de água e energia. Dentro de um contexto mais abrangente, como o do processo AQUA, esses itens correspondem a uma pequena parcela de contribuição, como veremos mais adiante na comparação dos itens.

Os itens de sustentabilidade do empreendimento Ecolife Independência são:

1. Pré-aquecimento da água dos chuveiros da suíte com energia solar

2. Iluminação com sensores de presença nas áreas comuns.

3. Reuso de águas cinzas para irrigação dos jardins.

4. Redutor de vazão de água nos chuveiros.

5. Torneiras com temporizador.

6. Torneiras com arejador.

7. Aproveitamento de águas pluviais.

8. Coleta seletiva de lixo.

9. Medidores individuais de água nos apartamentos. 
10. Medidores individuais de gás nos apartamentos.

11. Telhado ecológico sobre a guarita.

12. Coleta de óleo de cozinha.

13. Água filtrada na torneira dos apartamentos.

14. Churrasqueira a gás, com pedras vulcânicas.

15. Elevadores com alta eficiência.

16. Aquecimento a gás da água do chuveiro.

17. Iluminação de áreas comuns com energia solar (balizas, hall e iluminação de emergência).

18. Lâmpadas econômicas.

19. Motores de alta performance.

20. Paisagismo com baixa irrigação e microclima agradável.

21. Estação de tratamento de esgoto.

\section{Comparação dos itens de sustentabilidade do empreendimento com os} requisitos do sistema $A Q U A$

Devido a pouca informação disponível para realização da análise, em função do impedimento de comunicação com a empresa, alguns itens de comparação não foram conhecidos. Foram preenchidos com "SIM" os itens constantes na lista de diferenciais de sustentabilidade, divulgada pela empresa, e os itens que dizem respeito às normas e legislações, pois entende-se que são obrigatórios para que seja autorizada a construção, pelos departamentos da Prefeitura do Município de São Paulo. Os itens marcados com "- -" são aspectos não confirmados através da análise dos dados disponíveis, portanto, não se concluiu se são presentes ou ausentes. Os itens que se tem conhecimento de que não foram abordados foram preenchidos com "NÃO". Para o preenchimento da planilha, algumas informações foram conseguidas através de colegas profissionais que trabalham em escritório de arquitetura que presta serviços à 
EcoEsfera Empreendimentos Sustentáveis, onde trabalhou, também, a autora deste trabalho. Segue a planilha de comparação do estudo:

Tabela 4.1. Comparação entre os itens de sustentabilidade do Ecofile Independência e os requisitos do processo AQUA de certificação

\section{EDIFÍCIO CERTIFICADO AQUA - nível B}

\section{ECOLIFE INDEPENDÊNCIA}

\section{Categoria 1. Relação do edifício com seu entorno}

\section{Categoria 2. Escolha integrada de produtos, sistemas e processos construtivos}

Escolha de produtos, sistemas e processos construtivos a fim de limitar os impactos socioambientais da construção

\begin{tabular}{|c|c|c|}
\hline \multirow{6}{*}{$\begin{array}{l}\text { Conformidade de } \\
\text { produtos, sistemas e } \\
\text { processos com as } \\
\text { normas PBQP-H ou } \\
\text { IPT ou INMETRO }\end{array}$} & Estrutura portante vertical & SIM \\
\hline & Estrutura portante horizontal & SIM \\
\hline & Fachadas & SIM \\
\hline & Coberturas & SIM \\
\hline & Divisórias de separação / distribuição & SIM \\
\hline & Revestimentos internos & SIM \\
\hline \multirow{3}{*}{ Escolha de produtos } & Uso de cimento CP III ou CP IV para concretos moldados in loco & -- \\
\hline & $30 \%$ de produtos fabricados a menos de $300 \mathrm{~km}$ da obra & NÃO \\
\hline & Madeira e produtos de madeira certificada e de reflorestamento & NÃO \\
\hline \multicolumn{3}{|c|}{ Escolhas construtivas considerando a facilidade de conservação da construção } \\
\hline \multirow[b]{2}{*}{$\begin{array}{l}\text { Facilidade de } \\
\text { conservação }\end{array}$} & Produtos de construção de fácil conservação & NÃO \\
\hline & $\begin{array}{l}\text { Facilidade de acesso para manutenção de fachadas, telhados, } \\
\text { revestimentos internos, janelas, esquadrias, proteções solares, } \\
\text { divisórias internas e forros }\end{array}$ & NÃO \\
\hline Revestimentos de piso & $\begin{array}{l}\text { Pisos com resistência média ou elevada quanto ao desgaste em uso, } \\
\text { cargas verticais concentradas, resistência à umidade e ataque químico }\end{array}$ & SIM \\
\hline \multicolumn{3}{|c|}{ Escolha de fabricantes que não pratiquem a informalidade na cadeia produtiva } \\
\hline $\begin{array}{l}\text { Fabricantes que não } \\
\text { pratiquem a } \\
\text { informalidade }\end{array}$ & $\begin{array}{l}50 \% \text { do total de materiais das estruturas, contrapiso, argamassa, } \\
\text { revestimentos de piso, sistemas prediais e pintura }\end{array}$ & - - \\
\hline \multicolumn{3}{|c|}{ Acessibilidade e adaptabilidade da unidade habitacional ao envelhecimento } \\
\hline Acessibilidade & Acessibilidade atendendo à normalização técnica NBR9050 & SIM \\
\hline \multirow{4}{*}{$\begin{array}{l}\text { Respeito às seguintes } \\
\text { recomendações para o } \\
\text { mobiliário: }\end{array}$} & Otimizar bancada disponível como plano de trabalho na cozinha & SIM \\
\hline & Dar preferência a gaveteiros, prateleiras e portas de correr & NÃO \\
\hline & Não prever rodapés nos móveis de cozinha & NÃO \\
\hline & Móveis sob a pia da cozinha devem ter parte frontal desmontável & NÃO \\
\hline \multicolumn{3}{|c|}{ Organização e planejamento da cozinha } \\
\hline Projeto da cozinha & $\begin{array}{l}\text { Projeto demonstrando a previsão de localização e dimensionamento dos } \\
\text { eletrodomésticos, com previsão dos pontos de elétrica, água e esgoto. }\end{array}$ & SIM \\
\hline
\end{tabular}




\begin{tabular}{|c|c|c|}
\hline \multirow{2}{*}{$\begin{array}{l}\text { Vias de circulação, } \\
\text { vagas para veículos, } \\
\text { estacionamentos e } \\
\text { entregas }\end{array}$} & Respeitar exigências regulamentares e administrativas & SIM \\
\hline & $\begin{array}{l}\text { Organizar as entregas e retiradas de forma conjunta com serviços } \\
\text { administrativos pertinentes }\end{array}$ & NÃO \\
\hline \multirow{2}{*}{$\begin{array}{l}\text { Limpeza do entorno do } \\
\text { canteiro de obras }\end{array}$} & Dispositivos de limpeza das rodas dos caminhões (se necessário) & NÃO \\
\hline & Manutenção da limpeza do entorno do canteiro de obras & NÃO \\
\hline \multirow{2}{*}{ Incômodos sonoros } & Sensibilização do pessoal do canteiro de obras & NÃO \\
\hline & Planejamento das atividades ruidosas & NÃO \\
\hline \multicolumn{3}{|c|}{ Limitação dos riscos de poluição podendo afetar o terreno, os trabalhadores e a vizinhança } \\
\hline \multirow{3}{*}{\begin{tabular}{l|} 
Respeito à legislação e \\
aos regulamentos \\
relacionados aos \\
seguintes pontos:
\end{tabular}} & Queima de produtos & SIM \\
\hline & Betoneira com reservatório para recuperação das águas para reúso & SIM \\
\hline & Emprego de ferramentas munidas de filtro de material particulado & SIM \\
\hline \multirow{2}{*}{ Produtos perigosos } & $\begin{array}{l}\text { Previsão de estocagem isolada e adaptada aos impactos das } \\
\text { substâncias perigosas, sinalização e recuperação de rejeitos }\end{array}$ & - \\
\hline & Produtos menos poluentes: empregar desmoldante de origem vegetal & -- \\
\hline \multicolumn{3}{|c|}{ Gestão de resíduos do canteiro de obras } \\
\hline \multirow{3}{*}{$\begin{array}{l}\text { Exigências voltadas à } \\
\text { gestão e à valorização } \\
\text { dos resíduos de } \\
\text { construção e } \\
\text { demolição }\end{array}$} & $\begin{array}{l}\text { Terceirizados devem estabelecer uma lista estimativa dos resíduos } \\
\text { produzidos nas diferentes etapas da obra }\end{array}$ & NÃO \\
\hline & $\begin{array}{l}\text { Terceirizados devem calcular as quantidades dos resíduos produzidos } \\
\text { nas diferentes etapas da obra }\end{array}$ & NÃO \\
\hline & $\begin{array}{l}\text { Terceirizadas devem fornecer ao empreendedor os registros relativos à } \\
\text { eliminação de resíduos: composição e destinação / triagem }\end{array}$ & NÃO \\
\hline \multirow{4}{*}{$\begin{array}{l}\text { Desconstrução seletiva } \\
\text { (planejamento) }\end{array}$} & Diagnóstico dos resíduos das construções a demolir & NÃO \\
\hline & Composição e destinação dos resíduos & NÃO \\
\hline & Triagem e gestão dos resíduos de demolição & NÃO \\
\hline & Cadeias de reciclagem & NÃO \\
\hline \multicolumn{3}{|c|}{ Categoria 4. Gestão da energia } \\
\hline \multicolumn{3}{|c|}{ Redução do consumo de energia por meio da concepção arquitetônica } \\
\hline $\begin{array}{l}\text { Aptidão da envoltória } \\
\text { para limitar } \\
\text { desperdícios de } \\
\text { energia }\end{array}$ & $\begin{array}{l}\text { Transmitância térmica ponderada da envoltória conforme fórmula } \\
\text { proposta }\end{array}$ & NÃO \\
\hline \multicolumn{3}{|c|}{ Redução do consumo de energia primária não renovável (Cep) } \\
\hline $\begin{array}{l}\text { Estudo térmico: nível } \\
\text { de consumo de } \\
\text { energia para controle } \\
\text { de temperatura interna }\end{array}$ & $\begin{array}{l}\text { Equipamentos para resfriamento e aquecimento de ambientes com } \\
\text { etiquetagem da categoria C de eficiência energética do Inmetro + } \\
\text { cálculo do Cep }\end{array}$ & NÃO \\
\hline $\begin{array}{l}\text { Estudo energético: } \\
\text { nível de consumo de } \\
\text { energia para demais } \\
\text { equipamentos }\end{array}$ & $\begin{array}{l}\text { Utilização da etiquetagem da categoria C do Inmetro de eficiência } \\
\text { energética como referência na escolha dos demais equipamentos + } \\
\text { cálculo do Cep }\end{array}$ & NÃO \\
\hline \multirow{3}{*}{$\begin{array}{l}\text { Controle do consumo } \\
\text { de energia nas áreas } \\
\text { comuns }\end{array}$} & $\begin{array}{l}\text { lluminação com lâmpadas de baixo consumo e fluorescentes para áreas } \\
\text { com iluminação permanente }\end{array}$ & SIM \\
\hline & Iluminação com temporizadores e sensores de presença & SIM \\
\hline & Circuito elétrico do hall deve ser independente das outras circulações & -- \\
\hline \multicolumn{3}{|l|}{ Produção de água quente } \\
\hline $\begin{array}{l}\text { Produção de água } \\
\text { quente }\end{array}$ & A produção de água quente respeita os dimensionamentos propostos & SIM \\
\hline $\begin{array}{l}\text { Desempenho do } \\
\text { sistema para produção } \\
\text { de água quente }\end{array}$ & O empreendedor deve garantir o desempenho mínimo de $40 \%$ & NÃO \\
\hline
\end{tabular}




\begin{tabular}{|c|c|c|}
\hline \multicolumn{3}{|c|}{ Redução do consumo de água potável } \\
\hline \multirow{5}{*}{$\begin{array}{l}\text { Implementação de } \\
\text { sistemas } \\
\text { economizadores }\end{array}$} & Pressão estática a 300kPa com válvula redutora de pressão & -- \\
\hline & $\begin{array}{l}\text { Bacia sanitária com capacidade menor ou igual a } 6 \text { litros, com } \\
\text { mecanismo duplo }\end{array}$ & SIM \\
\hline & $\begin{array}{l}\text { Bacia sanitária, caixa acoplada e mecanismo de acionamento devem } \\
\text { estar de acordo com norma ABNT e fabricante com participação no } \\
\text { respectivo PSQ do PBPQ-H }\end{array}$ & SIM \\
\hline & Metais sanitários com componentes economizadores & SIM \\
\hline & $\begin{array}{l}\text { Aparelhos sanitários para água quente com misturadores em } \\
\text { conformidade com as normas técnicas da ABNT e fabricante com } \\
\text { participação no respectivo PSQ do PBPQ-H }\end{array}$ & SIM \\
\hline \multicolumn{3}{|l|}{ Gestão de águas pluviais } \\
\hline $\begin{array}{l}\text { Otimização da gestão } \\
\text { de águas pluviais, em } \\
\text { função da análise do } \\
\text { terreno }\end{array}$ & $\begin{array}{l}\text { Respeito à exigência da vazão de escoamento do terreno. Deve ser } \\
\text { feito o cálculo considerando uma intensidade pluviométrica com período } \\
\text { de retorno de } 10 \text { anos }\end{array}$ & NÃO \\
\hline \multicolumn{3}{|c|}{ Categoria 6. Gestão dos resíduos de uso e operação do edifício } \\
\hline $\begin{array}{l}\text { Adequação entre a } \\
\text { coleta interna e a } \\
\text { coleta externa }\end{array}$ & $\begin{array}{l}\text { Sistema de coleta interna deve ser coerente com a coleta externa. Tanto } \\
\text { nas práticas quanto nos horários }\end{array}$ & SIM \\
\hline \multicolumn{3}{|c|}{ Otimização do sistema de coleta interna considerando os locais de produção, armazenamento, coleta e retirada } \\
\hline $\begin{array}{l}\text { Otimização dos } \\
\text { circuitos de coleta }\end{array}$ & $\begin{array}{l}\text { Armazenamento em local de fácil acesso a partir das unidades } \\
\text { habitacionais }\end{array}$ & SIM \\
\hline $\begin{array}{l}\text { Armazenamento dos } \\
\text { resíduos }\end{array}$ & $\begin{array}{l}\text { O local do armazemanento deve ser dimensionado de forma coerente } \\
\text { com os fluxos de entrada e saída de resíduos }\end{array}$ & SIM \\
\hline \multicolumn{3}{|c|}{ Categoria 7. Gestão da manutenção } \\
\hline \multicolumn{3}{|c|}{ Facilidade de acesso para execução da manutenção e simplicidade das operações } \\
\hline \multirow[b]{2}{*}{ Para a gestão da água } & Medidor individual facilmente acessível na parte comum & SIM \\
\hline & $\begin{array}{l}\text { Exixtência de um registro acessível, permitindo isolar a unidade } \\
\text { habitacional (água fria e água quente) }\end{array}$ & SIM \\
\hline $\begin{array}{l}\text { Para a gestão dos } \\
\text { resíduos }\end{array}$ & $\begin{array}{l}\text { Todo local de armazenamento de resíduos, interna ou externamente, } \\
\text { deve ser bem iluminado, equipado com um ponto de água com registro } \\
\text { e com tubulação de esgoto }\end{array}$ & - - \\
\hline $\begin{array}{l}\text { Para a gestão de } \\
\text { outros equipamentos } \\
\text { técnicos }\end{array}$ & $\begin{array}{l}\text { O conjunto dos equipamentos técnicos deve ser acessível e } \\
\text { informações sobre sua manutenção devem constar do manual } \\
\text { destinado aos futuros ocupantes e aos responsáveis pela operação e } \\
\text { manutenção do edifício }\end{array}$ & - \\
\hline \multicolumn{3}{|c|}{ Categoria 8. Conforto Higrotérmico } \\
\hline \multirow{3}{*}{$\begin{array}{l}\text { Implantação de medida } \\
\text { O empreendedor leva } \\
\text { em conta as } \\
\text { características do local } \\
\text { do empreendimento } \\
\text { (principalmente no } \\
\text { verão) }\end{array}$} & arquitetônicas para otimização do conforto higrotérmico no inv & \\
\hline & Medidas adotadas para proteção ótima quanto ao sol e calor & NÃO \\
\hline & $\begin{array}{l}\text { Concepção arquitetônica adequada para melhora da aptidão do edifício } \\
\text { de modo a favorecer as boas condições higrotérmicas no verão e no } \\
\text { inverno }\end{array}$ & NÃO \\
\hline \multirow{2}{*}{$\begin{array}{l}\text { Conforto higrotérmico } \\
\text { de verão }\end{array}$} & $\begin{array}{l}\text { Temperatura máxima do ar interior de ambientes de permanência } \\
\text { prolongada, sem apresença de fontes internas de calor, deve ser menor } \\
\text { do que o valor máximo diário da temperatura do ar externo (demonstrar } \\
\text { por meio de simulação ou medição in loco) }\end{array}$ & NÃO \\
\hline & $\begin{array}{l}\text { Elementos opacos (materiais) empregados demodo que estejam } \\
\text { adequados à zona bioclimática brasileira, e respeitando os níveis de } \\
\text { fator solar presentes na nota }\end{array}$ & NÃO \\
\hline
\end{tabular}


Conforto higrotérmico de inverno
Temperatura mínima do ar interior de ambientes de permanência prolongada, no dia típico de inverno, devem ser sempre maiores ou iguais à temperatura mínima externa acrescida de $3^{\circ} \mathrm{C}$ (demonstrar por meio de simulação ou medição in loco)

\section{Categoria 9. Conforto acústico}

Conforto acústico entre a unidade habitacional e os outros locais de uma mesma edificação

Quando o local de
emissão for um outro
ambiente interno

Nível de pressão ponderado do ruído de impacto L'nTw menor ou igual a $80 \mathrm{Db}$, obtido por meio de dispositivos atenuadores

Medidas arquitetônicas e dispositivos adequados para garantir isolamento acústico entre a unidade habitacional e os outros locais de uma mesma edificação

Conforto acustico entre os

\section{Conforto acústico entre os cômodos principais e o exterior}

\section{Respeito à}

normalização

Isolamento acústico padrão ponderado frente aos ruídos externos
Respeito à normalização técnica e à regulamentação local aplicável, comprovado por estudo de avaliação acústica abrangendo as disposições construtivas previstas

Medidas arquitetônicas e dispositivos adequados para garantir isolamento acústico padrão frente aos ruídos externos
NÃO

NÃO

NÃO

NÃO

\section{Categoria 10. Conforto visual}

Aproveitar da melhor maneira os benefícios da iluminação natural

As salas de estar das unidades habitacionais devem dispor de um índice de abertura superior a $15 \%$

Dispor de uma iluminação artificial confortável

Nível de iluminância

\section{Comando de}

iluminação

\section{Dispor de uma} iluminação artificial das zonas exteriores confortável e segura

Hall de entrada: nível de iluminância média entre 100 e 200 lux

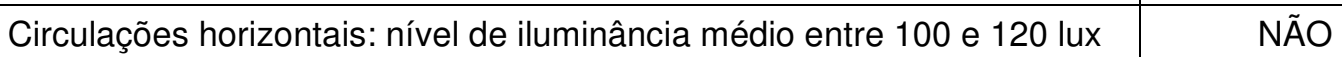
Escadas: nível de iluminância médio entre 150 e 160 lux $\quad$ NÃO

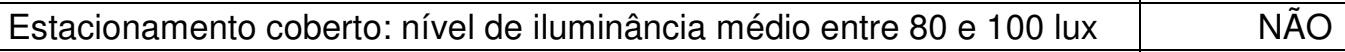
$\begin{array}{ll}\text { Detector de presença no hall, na entrada, nas circulações horizontais, } & \text { SIM }\end{array}$ nas escadas e nos estacionamentos cobertos

Instalar sensores fotoelétricos dia/noite para gerenciar o acionamento e $\quad$ NÃO o desligamento da iluminação exterior \begin{tabular}{l|l} 
Utilizar luminárias que possuam refletores orientados para o solo & NÃO
\end{tabular}

Projetar iluminações dos caminhos e circulações de forma a não serem encobertas pela vegetação

\section{Categoria 11. Conforto Olfativo}

Ventilação eficiente

Ventilação eficiente

Boa distribuição de ar novo e ótima exaustão do ar viciado

Controle das fontes de odores desagradáveis

Controle das fontes de odores desagradáveis exterior
Seguir a norma ABNT NBR 13103 - Adequação de ambientes residenciais para instalação de aparelhos que utilizam gás combustível Adotar valores do código de obras local

Estudo cuidadoso do posicionamento das aberturas para uma ótima disposição (incluindo proximidade a fontes de poluição e umidade) Identificação das fontes de odores desagradáveis que provém do

Propor soluções arquitetônicas e técnicas para limitar os efeitos de odores provenientes do exterior

Locais de armazenamento dos resíduos devem ser arejados e ventilados
NÃO

NÃO

SIM 
O sistema predial de esgoto sanitário deve ser projetado de modo a impedir que os gases provenientes do interior do sistema atinjam áreas de utilização

\section{Categoria 12. Qualidade Sanitária dos Ambientes}

Criar boas condições de higiêne

Instalação de revestimentos em vedações verticais contíguas a aparelhos sanitários (em placa cerâmica ou similar em termos de estanqueidade à água) com uma altura "h" mínima de proteção dada por legislação estadual vigente

Os cômodos das unidades habitacionais dotados de ponto de alimentação de água devem ter as vedações verticais dotadas de hidrofugantes ou que não degradem com água

\section{Categoria 13. Qualidade sanitária do ar}

Ventilação eficiente

Ventilação

Boa distribuição de ar novo e ótima exaustão do ar viciado

Seguir a norma ABNT NBR 13103 - Adequação de ambientes \begin{tabular}{l|r} 
Seguir a norma ABNT NBR 13103 - Adequação de ambientes & SIM \\
residenciais para instalação de aparelhos que utilizam gás combustível & SIM
\end{tabular}

Adotar valores do código de obras local

ras local

Estudo cuidadoso do posicionamento das aberturas para uma ótima disposição (incluindo proximidade a fontes de poluição e umidade)

Controle das fontes de poluição

Considerar as

condições do local do empreendimento

Escolher produtos de construção de modo a limitar os impactos da construção à qualidade do ar interior e à saúde da construção

\section{Categoria 14. Qualidade sanitária da água}

Assegurar a manutenção da qualidade da água destinada ao consumo humano das redes internas do edifício

Sistema central coletivo

Informações sobre a qualidade da água

Sistema de aproveitamento de água pluvial

Risco de queimaduras e legionelose
No caso de identificação de poluição do solo, na análise do local do empreendimento, o empreendedor deve fornecer a prova de ter realizado uma despoluição eficaz ou o tratamento do terreno antes da construção

Não empregar produtos à base de amianto ou que contenham amianto em sua composição

No caso do projeto luminotécnico, especificar lâmpadas fluorescentes compactas e circulares e utilizar apenas as que apresentem o selo do Procel

\begin{tabular}{|l|c|}
\hline $\begin{array}{l}\text { Distribuição de água quente deve ser mantida na temperatura por um } \\
\text { circuito fechado. }\end{array}$ & SIM \\
\hline $\begin{array}{l}\text { Tubulações embutidas e aparentes devem ser protegidas com um } \\
\text { isolante térmico }\end{array}$ & SIM \\
\hline Respeito às recomendações da NBR 7198:1993 e legislação local & SIM \\
\hline $\begin{array}{l}\text { Obter os resultados da análise da qualidade da água realizada antes do } \\
\text { hidrômetro e os resultados da análise da água que sai das torneiras } \\
\text { após a execução das instalações }\end{array}$ & NÃO \\
\hline $\begin{array}{l}\text { Deve haver separação de redes de água potável e água não potável } \\
\text { com identificação das tubulações por meio de cores }\end{array}$ & SIM \\
\hline Obtenção de declarações e autorizações sanitárias necessárias & SIM \\
\hline $\begin{array}{l}\text { Instalações de produção e distribuição de água quente devem seguir as } \\
\text { exigências referentes à prevenção dos riscos relacionados à legionelose } \\
\text { e às queimaduras }\end{array}$ & SIM \\
\hline Temperatura máxima da água em $50^{\circ} C$ nos pontos de consumo & SIM \\
\hline
\end{tabular}

Itens atendidos pelo empreendimento $(\mathrm{SIM})=44$

Itens não atendidos pelo empreendimento $(\mathrm{NÃO})=45$

Itens não confirmados (- -) = 11 
A análise da planilha permite algumas considerações:

1. Os itens atendidos pelo empreendimento correspondem a aproximadamente $44 \%$ dos requisitos do sistema AQUA, para o nível mais baixo de certificação (BOM). Os itens não atendidos correspondem a $45 \%$ dos requisitos do sistema. Com o atendimento de menos da metade dos itens, o empreendimento Ecolife Independência não seria certificado pelo sistema AQUA.

2. A "Categoria 1. Relação do Edifício com seu entorno" não foi analisada porque a certificação em nível BOM do sistema não exige ações e planejamentos nesta categoria, embora ela seja de grande importância para a existência de sustentabilidade. Se a categoria 1 fosse considerada nesta análise, 24 dos seus 30 requisitos não seriam atendidos.

Gráfico 4.1. Atendimento às categorias do processo AQUA pelo Ecolife Independência

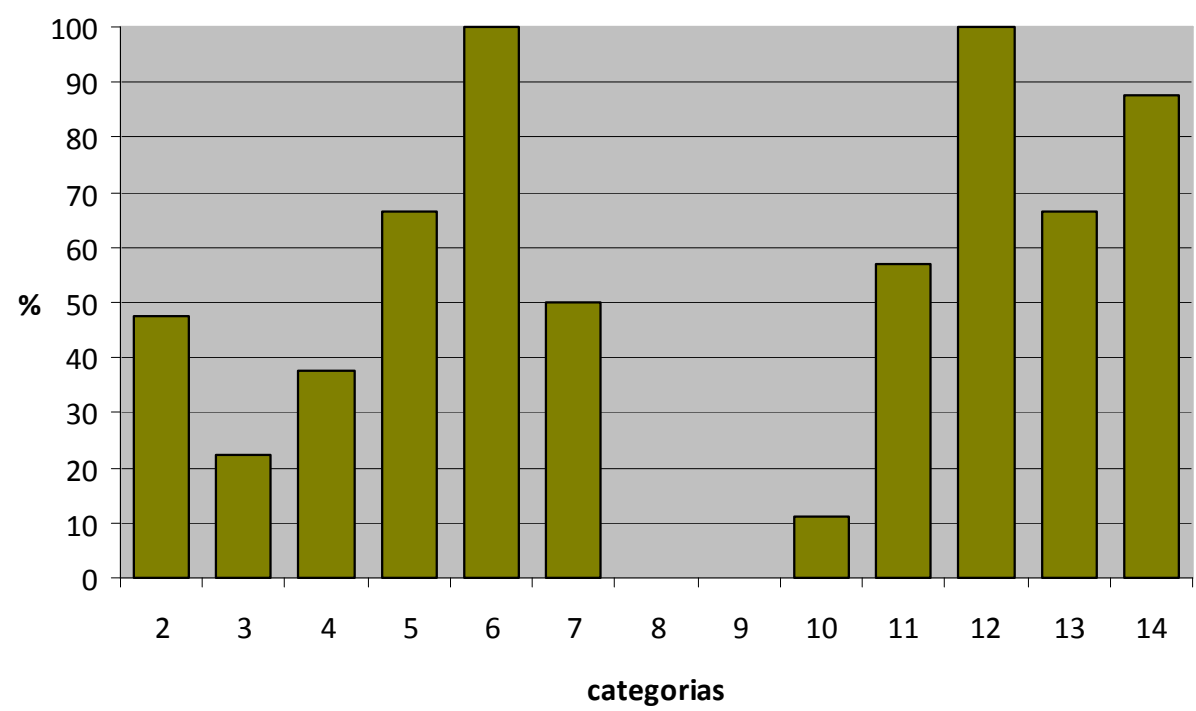

3. As Categorias 8 (Conforto Higrotérmico) e 9 (Conforto Acústico) não foram atendidas em nenhum requisito, o que pressupõe o não planejamento dos aspectos que garantem conforto interno para o morador, no que diz respeito à temperatura, 
umidade do ar, incidência solar e conforto acústico, por meio de soluções arquitetônicas.

4. As categorias melhor atendidas foram: Categoria 6 (Gestão de Resíduos de Uso e Operação do Edifício), Categoria 12 (Qualidade Sanitária dos Ambientes) e Categoria 14 (Qualidade Sanitária da Água), que são categorias relacionadas ao Código Sanitário do Estado de São Paulo, o qual deve ser atendido obrigatoriamente por todos os empreendimentos, sustentáveis ou não.

\section{Considerações finais sobre o estudo do empreendimento Ecolife} Independência

A partir da comparação do empreendimento com o processo AQUA de certificação, concluímos que o Ecolife Independência não pode ser considerado um empreendimento sustentável para os padrões brasileiros. O recebimento da précertificação LEED não garante o atendimento das necessidades ambientais, sociais e culturais, características da realidade do Brasil.

Outros fatores como o comportamento da empresa com relação ao cliente, a falta de preocupação com o atendimento das dúvidas e reclamações e a recusa em fornecer material para pesquisa mostram uma postura que vai contra os princípios de sustentabilidade. Transparência e atendimento à comunidade fazem parte dos requisitos do processo AQUA de certificação e são importantes para a harmonia da relação entre o empreendimento e seu entorno.

Procurando por informações sobre o empreendimento na rede internacional de comunicação, a internet, encontramos diversas reclamações não atendidas de moradores e proprietários de unidades de empreendimentos Ecolife, da Empresa EcoEsfera. A maioria das reclamações diz respeito ao atraso na entrega dos apartamentos, o que supõe o não cumprimento de um cronograma de obra. 0 planejamento das etapas da construção também consta na avaliação do processo AQUA. Também há reclamações sobre estouro de caixas d'água, infiltração e umidade 
nas unidades do térreo e nos subsolos, e sobre a fragilidade das rampas de veículos dos estacionamentos. Essas reclamações podem ser encontradas na internet e foram feitas por moradores de diferentes "Ecolifes". Os empreendimentos Ecolife Butantã, Ecolife Morumbi e Ecolife Independência foram os que receberam mais reclamações. Algumas dessas reclamações levaram até seis meses para serem atendidas pela empresa (informação verbal da moradora do Ecolife Butantã, Paula Suda ${ }^{1}$ ).

Essa postura da empresa EcoEsfera com relação às reclamações dos proprietários evidencia a distância que existe, atualmente, entre o construtor e o comprador do imóvel, fato que contribui para a baixa qualidade das construções.

\footnotetext{
1. Paula Suda é proprietária e moradora de uma unidade térrea do Ecolife Butantã. Após a ocupação do apartamento, entrou em contato com a empresa Ecoesfera para que fossem solucionados problemas de infiltração. Juntamente com outros moradores, ela já concedeu entrevistas a diversos meios de comunicação para falar sobre o problema, entre eles os jornais Estado de São Paulo e Folha de São Paulo.
} 


\subsection{Análise dos empreendimentos selecionados}

O estudo dos empreendimentos escolhidos dentro de um grupo de lançamentos considerados pelo mercado como sustentáveis, foi feito com base nas informações divulgadas pelas empresas construtoras. As informações sobre os itens atendidos por cada empreendimento foram encontradas por meio dos websites das empresas e através de contato telefônico, quando os dados disponíveis no website não foram suficientes para realizar a análise. Para este segundo estudo, não foram feitas análises mais aprofundadas com relação à implantação, fachadas e plantas das unidades. Foram avaliados somente os itens de sustentabilidade divulgados por meio de campanhas de marketing, através de comparação com os requisitos do processo AQUA. Os itens atendidos pelo empreendimento e aqueles que dizem respeito às normas e legislações foram preenchidos com "SIM". Os itens não mencionados pelas empresas foram preenchidos com "---".

A seguir, apresentamos os empreendimentos analisados: 


\section{PLAZA MAYOR ALTO DA LAPA}

Localização: São Paulo - SP

Construtora EVEN

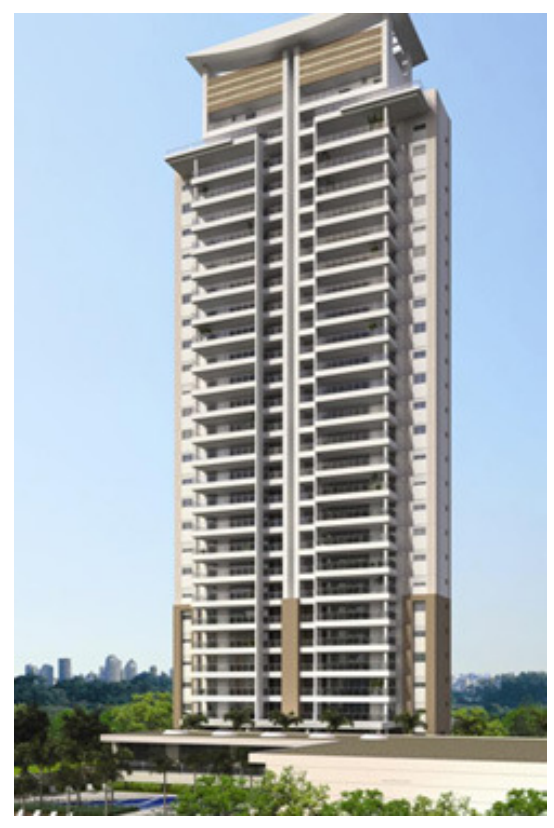

Figura 4.6. Fachada do Plaza Mayor Alto da Lapa Fonte: even.com.br

\section{Itens de sustentabilidade:}

1. Utilização de madeira certificada para todas as portas e uso de madeira de reflorestamento para as demais finalidades.

2. Uso de fôrmas prontas de madeira e reaproveitamento entre pavimentos.

3. Uso de fôrmas plásticas no canteiro de obras.

4. Na fachada, a cerâmica é colada direto na parede.

5. Brita reciclada para drenagem de jardim e outros locais que não exijam resistência dos materiais.

6. Gestão de resíduos durante o uso e operação do edifício.

7. Uso de tintas à base de água, com baixo composto orgânico volátil VOC.

8. Separação e encaminhamento de aço para reciclagem durante a obra.

9. Sistema de alvenaria modular.

10. Sistema de distribuição de instalações aparentes.

11. Painéis modulares reutilizáveis nos tapumes e nos canteiros de obra.

12. Chuveiros a gás.

13. Proteções metálicas na obra evitam o uso de madeira e podem ser reutilizadas.

14. Educação ambiental aos operários.

15. Setorização elétrica com timer e sensores de presença em áreas comuns. 
16. Elevadores com motores de alto desempenho.

17. Bacias sanitárias com duplo acionamento (sistema dual) nas áreas comuns.

18. Piso elevado nas áreas comuns.

19. Redutores de vazão em todos os pontos de consumo.

\section{PRÍNCIPE DE GREENFIELD}

Localização: Porto Alegre - RS

Construtora JOAL TEITELBAUM

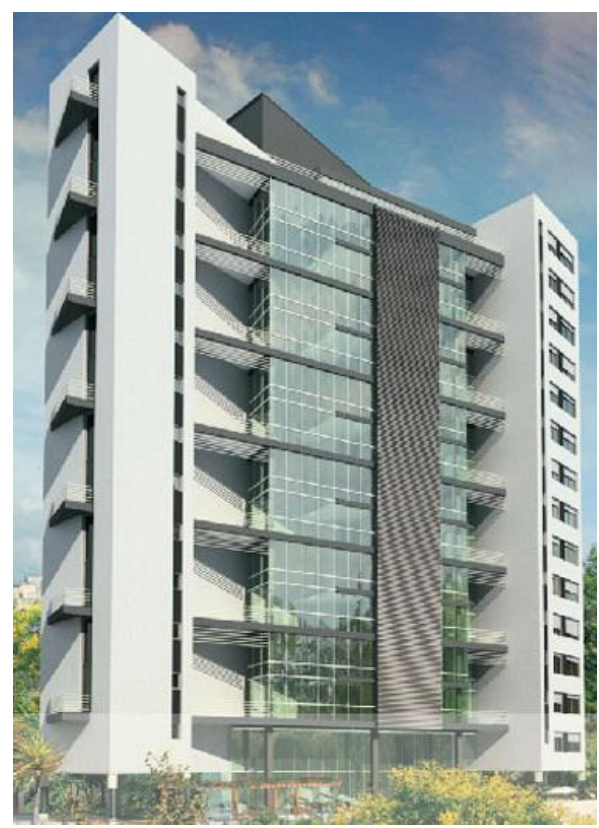

Figura 4.7. Fachada do Príncipe de Greenfield

Fonte: teitelbaum.com.br

\section{Itens de sustentabilidade}

1. Automação residencial (iluminação).

2. Instalação para ar condicionado com gás ecológico e alta eficiência energética.

3. Tratamento de esgoto.

4. Reúso de água para descargas sanitárias.

5. Captação e reuso de água da chuva para irrigação dos jardins.

6. Painéis solares e caldeira central para aquecimento da água.

7. Medidores individuais de água.

8. Depósito para lixo orgânico e seco.

9. Bicicletário.

11. Gerador parcial de energia. 
12. Estacionamento para visitantes.

13. Manual de gerenciamento ambiental para o condomínio.

\section{LATITUDE $23^{\circ}$}

Localização: Ubatuba - SP

\section{Construtora Atmosfera}

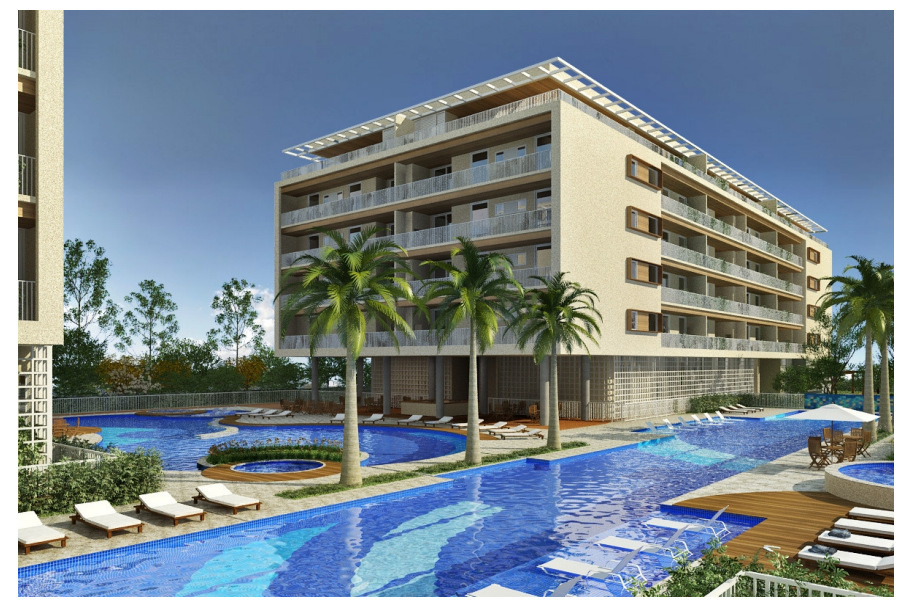

Figura 4.8. Fachada do Latitude $23^{\circ}$

Fonte: atmosfera.com.br

\section{Itens de sustentabilidade}

1. Estudo de insolação, iluminação e ventilação naturais.

2. Átrio para ventilação cruzada e efeito chaminé.

3. Cisterna para reaproveitamento de água da chuva. 


\section{MUNDO APTO BARRA FUNDA}

Localização: São Paulo - SP

Construtora SETIN

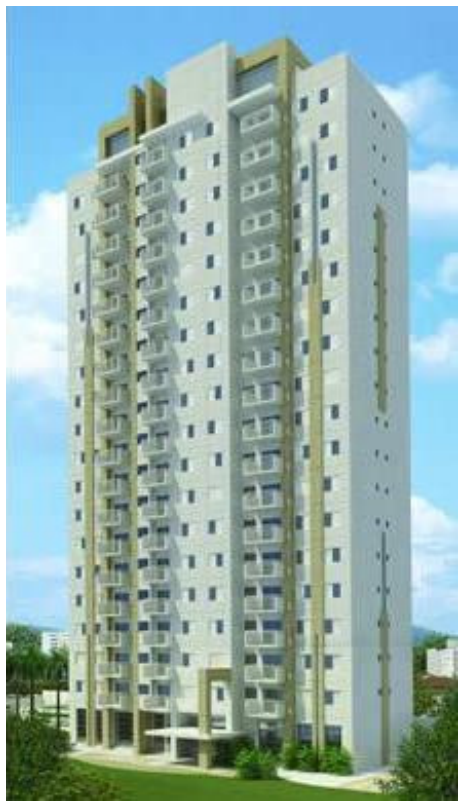

Itens de sustentabilidade

1. Aquecimento central solar e a gás.

2. Reúso de águas cinzas para uso nas bacias sanitárias.

3. Redutores de vazão nas torneiras e duchas.

3. Fachada pré-moldada.

Figura 4.9. Fachada do Mundo Apto Alto da Lapa

Fonte: setin.com.br

\section{ABSOLUTTO CONDOMÍNIO CLUBE}

Localização Aracajú - SE

Construtora STANZA

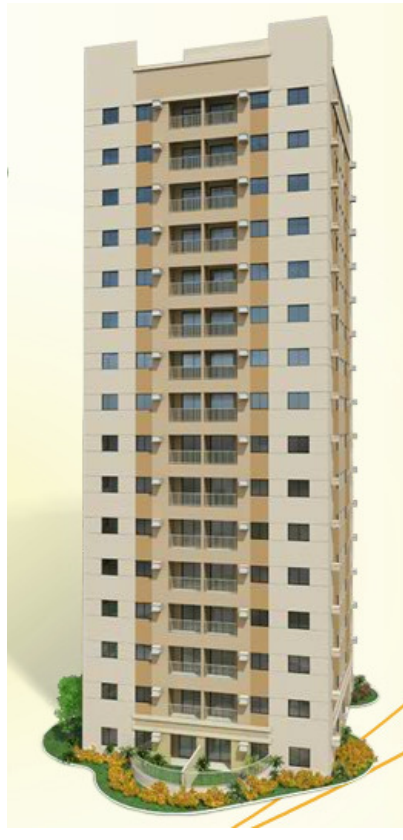

Itens de sustentabilidade

1. Poço artesiano para irrigação de jardins.

2. Coleta seletiva de lixo.

3. Captação de água da chuva.

4. Sensores de presença nas áreas comuns.

5. Torneiras com temporizadores.

8. Descarga com duplo acionamento, 3 e 6 litros.

8. Medição individual de água por unidade.

Figura 4.10. Fachada do Absolutto Condomínio Clube

Fonte: celi.com.br/stanza/absolutto 


\section{EVOLUTION ECOLOGIC RESIDENCE}

Localização: Salvador - BA

Incorporadora e Construtora ECOMUNDO

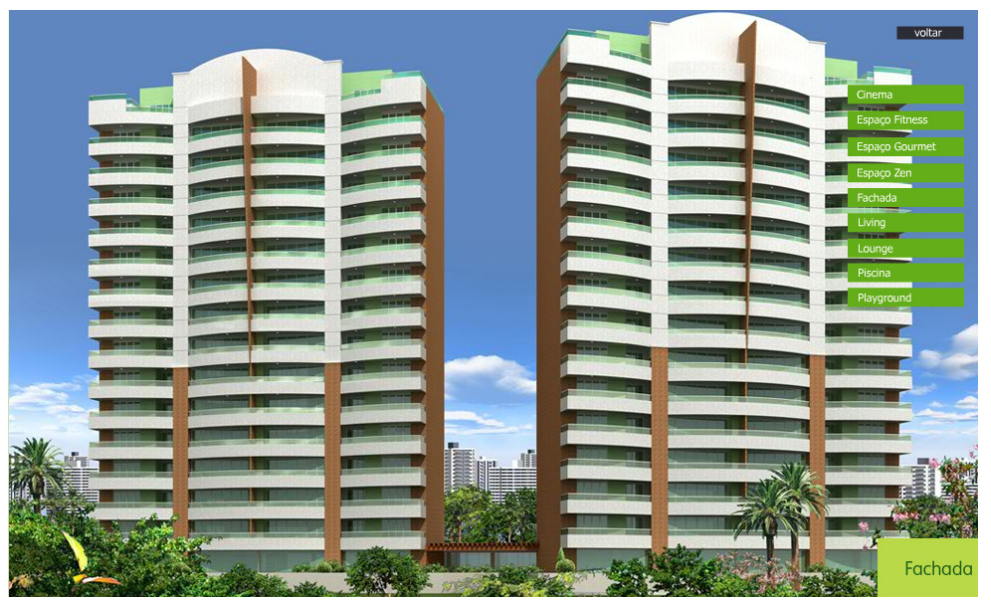

Figura 4.11. Fachada do Evolution Ecologic Residence

Fonte: Lopes.com.br/salvador/evolution

\section{Itens de sustentbilidade}

1. Reaproveitamento de águas cinzas nas bacias sanitárias.

2. Reaproveitamento de águas pluviais para irrigação de jardins.

3. Caixas de descarga com duplo acionamento (3 e 6 litros).

4. Medição individual de água nos apartamentos.

5. Aquecimento parcial da água dos chuveiros com energia solar.

6. Torneiras com temporizados nas áreas comuns.

7. Iluminação com sensores de presença nas áreas comuns.

8. Iluminação das escadas enclausuradas com sensores de presença.

9. Instalações hidráulicas não são embutidas em alvenarias, facilitando a manutenção.

10. Prumadas para energia elétrica, telefone, antena e dados em shafts visitáveis.

11. Medição individual de gás nos apartamentos.

12. Lâmpadas de alta eficiência nas áreas comuns e no paisagismo. 


\section{GREEN LIFE RESIDENCE}

Localização: Fortaleza - CE

Incorporadora e construtora IDIBRA

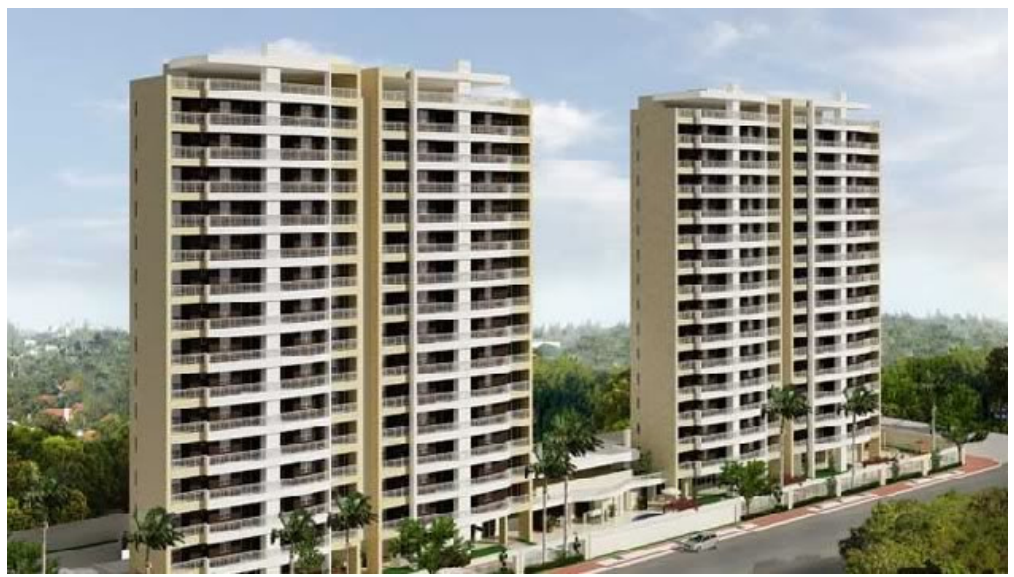

Figura 4.12. Fachada do Green Life Residence

Fonte: idibra.com.br

\section{Itens de sustentabilidade}

1. Energia solar para iluminação dos acessos de veículos e pedestres.

2. Piscina aquecida com energia solar.

3. Água dos chuveiros aquecida com energia solar.

4. Energia eólica para iluminação do hall de entrada.

5. Aproveitamento das águas cinzas nas bacias sanitárias.

6. Medição individual de água e gás nos apartamentos. 


\section{GREEN LIFE RESIDENCE 2}

Localização: Fortaleza - CE

Incorporadora e construtora IDIBRA

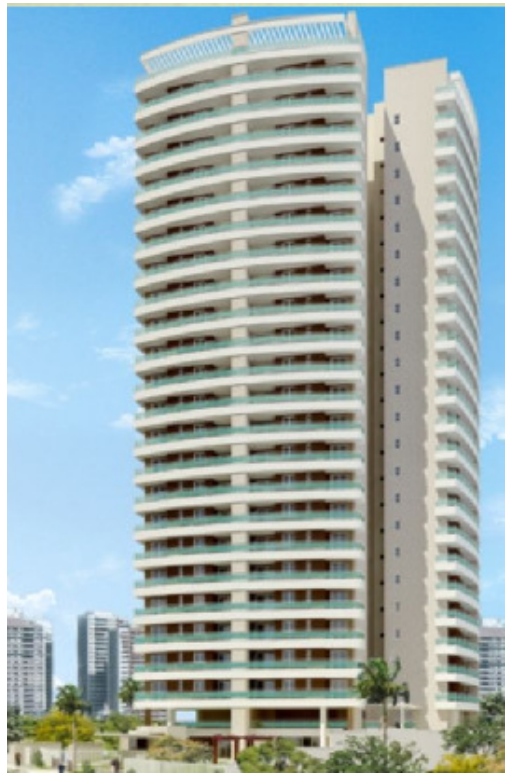

\section{Itens de sustentabilidade}

1. Iluminação das garagens e guarita com energia solar.

2. Aquecimento da piscina adulto com energia solar.

3. Aquecimento da água dos chuveiros da suíte máster com energia solar.

4. Iluminação do hall do térreo com energia eólica.

5. Triturador de resíduos na pia da cozinha.

6. Coleta seletiva de lixo.

Figura 4.13. Fachada do Green Life Residence 2

Fonte: idibra.com.br

\section{RESIDENCIAL EXCLUSIVE EUROVILLE}

Localização: Goiânia - GO

Construtora EUROAMERICA

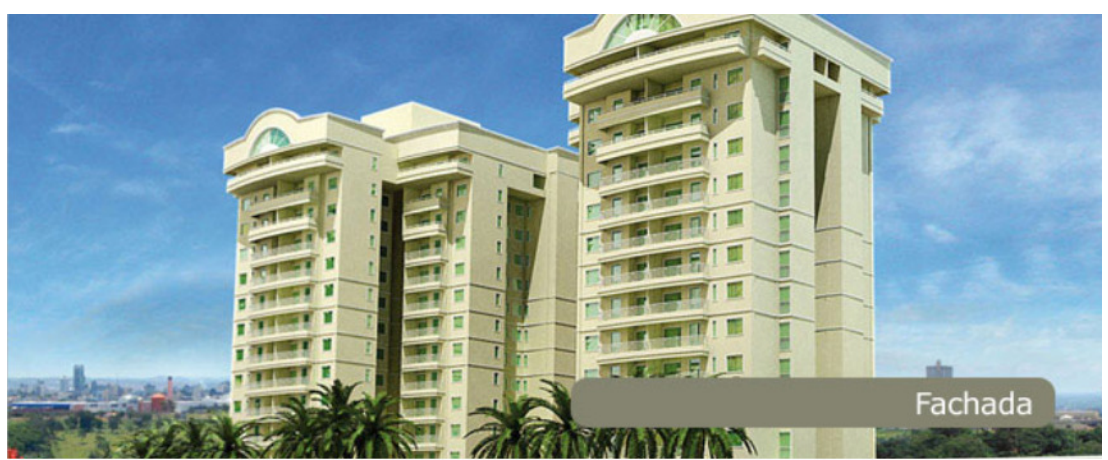

Figura 4.14. Fachada do Residencial Exclusive Euroville Fonte: euroamerica.com.br

\section{Itens de sustentabilidade}

1. Coleta seletiva de lixo.

2. Aquecimento da piscina com energia solar.

3. Reaproveitamento da água da chuva para irrigação de jardins. 
4. Iluminação com sensores de presença nas áreas comuns.

6. Telhas recicláveis nas torres dos edifícios.

7. Redutores de vazão em torneiras das áreas comuns.

8. Sistema de duplo acionamento de descarga.

9. Uso de bloco de concreto celular autoclavado.

\section{FELICITÀ ECO RESIDENCIAL}

Localização: Balneário Camboriú - SC

Construtora não informada

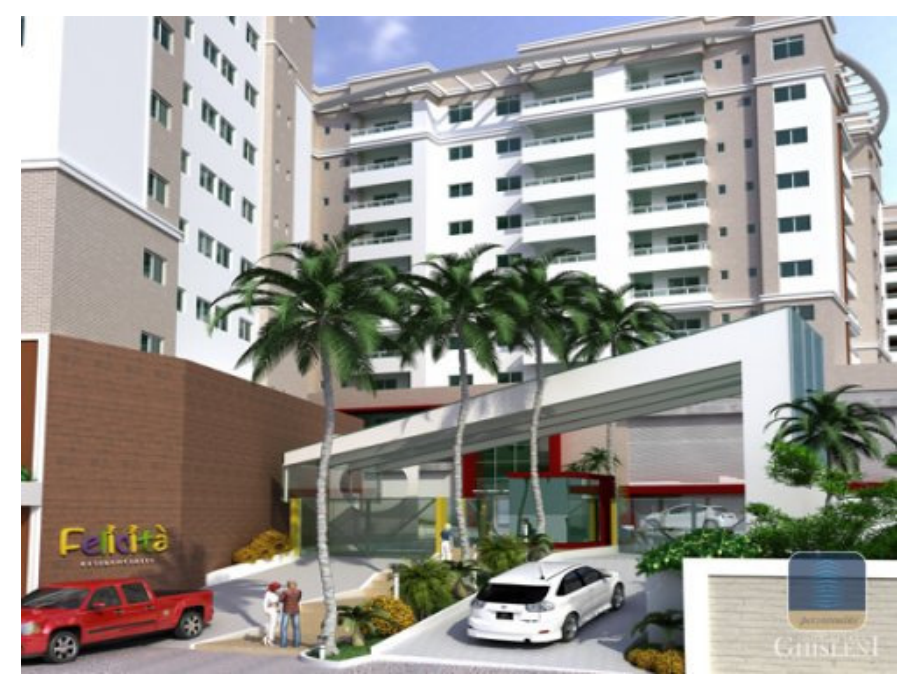

Figura 4.15. Fachada do Felicita Eco Residencial Fonte: viaimovel.com.br/felicitaecoresidencial

\section{Itens de sustentabilidade}

1. Captação de água da chuva para irrigação de áreas externas.

2. Energia solar e eólica para iluminação de áreas comuns.

3. Elevadores com alta eficiência. 


\section{ESMERALDA RESIDENCE}

Localização: Vitória - ES

Incorporadora e construtora MAZZINI

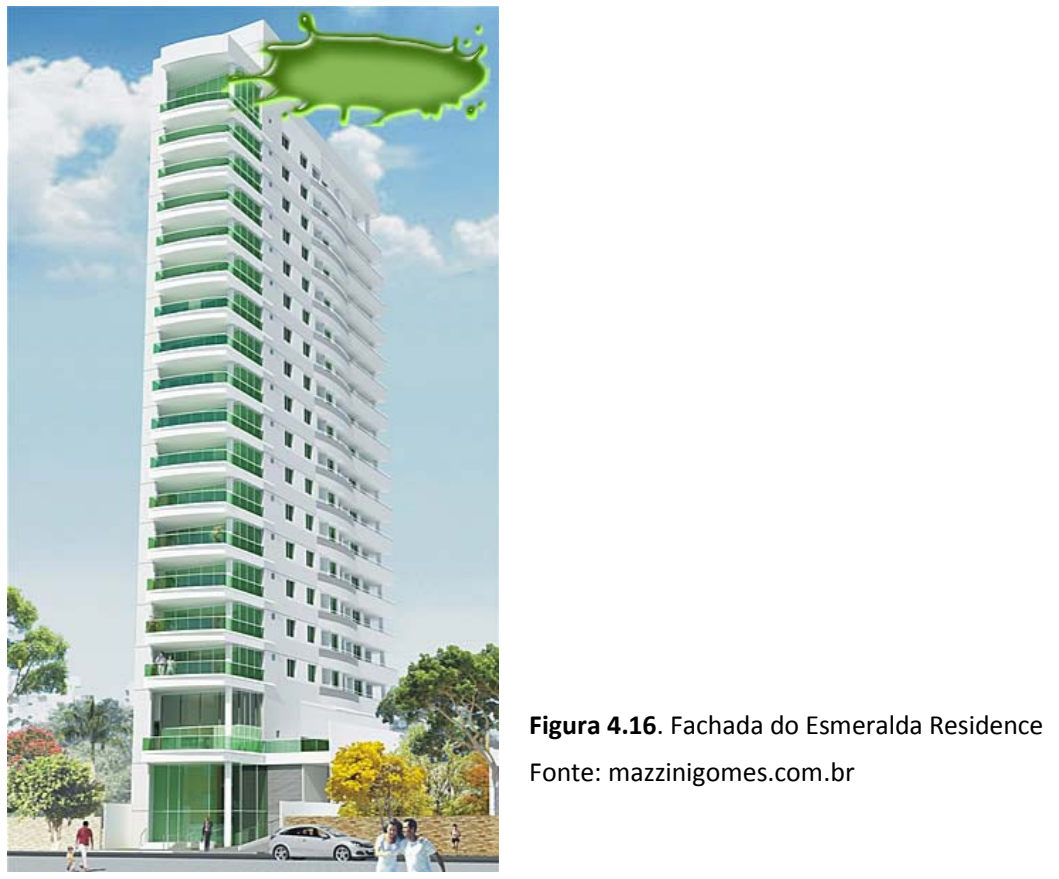

\section{Itens de sustentabilidade}

1. Plantio de árvores em áreas de reflorestamento.

2. ETAC - Estação de tratamento de águas cinzas.

3. Energia solar para aquecimento parcial da água.

4. Piso ecológico.

5. Caixa de descarga com acionamento duplo.

6. Coleta seletiva dos resíduos gerados durante a obra e controle do seu destino final.

7. Utilização de madeira de reflorestamento.

8. Granitos e cerâmicas comprados somente de fornecedores licenciados.

9. Captação e utilização da água da chuva na construção.

10. Reutilização das águas cinzas para uso em descargas de vaso sanitário em canteiro de obra.

11. Treinamento de funcionários em Gestão Ambiental.

12. Gestão de resíduos na construção.

13. Fachada aerada em granito.

14. Fôrmas de alumínio para laje. 


\section{RESIDENCIAL ECO PARQUE}

Localização: São José dos Campos - SP

Incorporadora e construtora COSTA VITUZZO

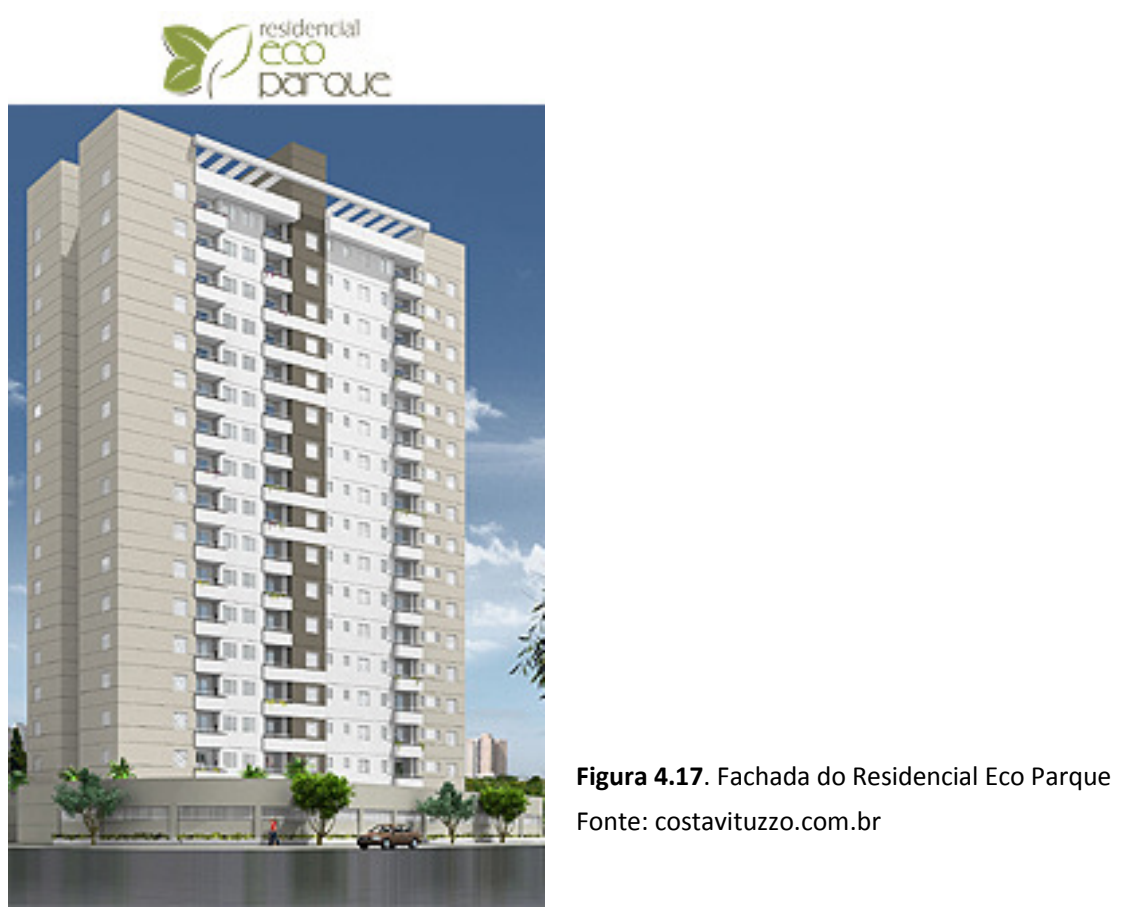

1. Lâmpadas e sensores de presença nas áreas comuns.

2. Medidores individuais de água e gás nos apartamentos.

3. Redutores de vazão de água nos chuveiros.

4. Sistema de redução de vazão de água nas bacias sanitárias dos apartamentos.

5. Venda de resíduos recicláveis, como óleo de cozinha.

6. Coleta seletiva de lixo.

7. Cobertura com proteção térmica - evita calor excessivo nos apartamentos da cobertura.

8. Elevadores com alta eficiência.

9. Incentivo do uso racional dos recursos aos usuários.

10. Reaproveitamento de materiais de outras obras. 


\section{M.O.R.E. ALPHAVILLE}

Localização: Alphaville, São Paulo - SP

Incorporadora e Construtora BKO

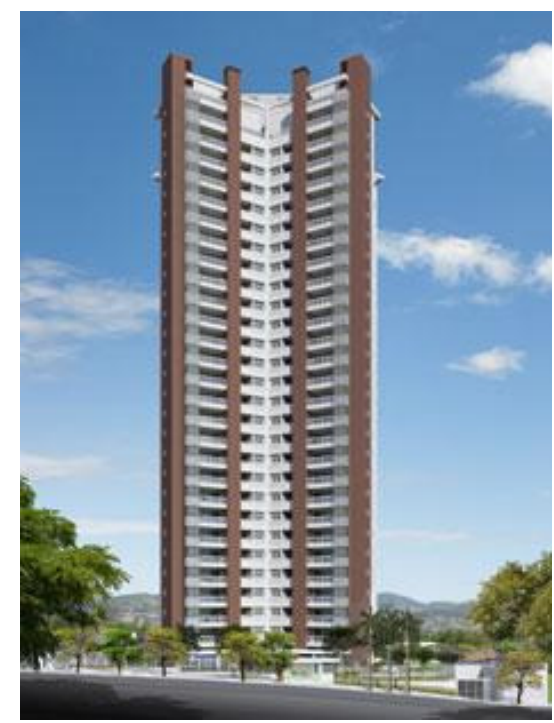

Figura 4.18. Fachada do MORE Alphaville

Fonte: bko.com.br

\section{Itens de sustentabilidade}

1. Implantação de espécies nativas de flora.

2. Espaço para cultivo e tratamento de espécies vegetais.

3. Promoção de áreas permeáveis.

4. Telhado verde.

5. Iluminação de áreas comuns com sensores de presença.

6. Iluminação com foco voltado para baixo no paisagismo.

7. Eletrodomésticos das áreas comuns com selo Procel.

8. Torneiras e chuveiros das áreas comuns com alta eficiência.

9. Dispositivos economizadores de água nas áreas comuns e privativas.

10. Descarga com duplo acionamento nas áreas comuns e privativas.

11. Sistema de recirculação de água nos chuveiros da suíte máster.

12. Infra-estrutura para gestão de resíduos dentro do condomínio.

13. Utilização de materiais de demolição.

14. Materiais com porcentagem de reciclagem.

15. Uso de materiais locais.

16. Produtos com baixa emissão de VOC (compostos orgânicos voláteis) em tintas, solventes, colas.

17. Áreas para bicicletário.

18. Palestras para equipe de manutenção do edifício.

21. Comunicação da Declaração de Sustentabilidade aos usuários. 
22. Manual ao proprietário com orientações ambientais.

\section{BELLA VITA ECO CLUB}

Localização: Santos - SP

Construtora GMR

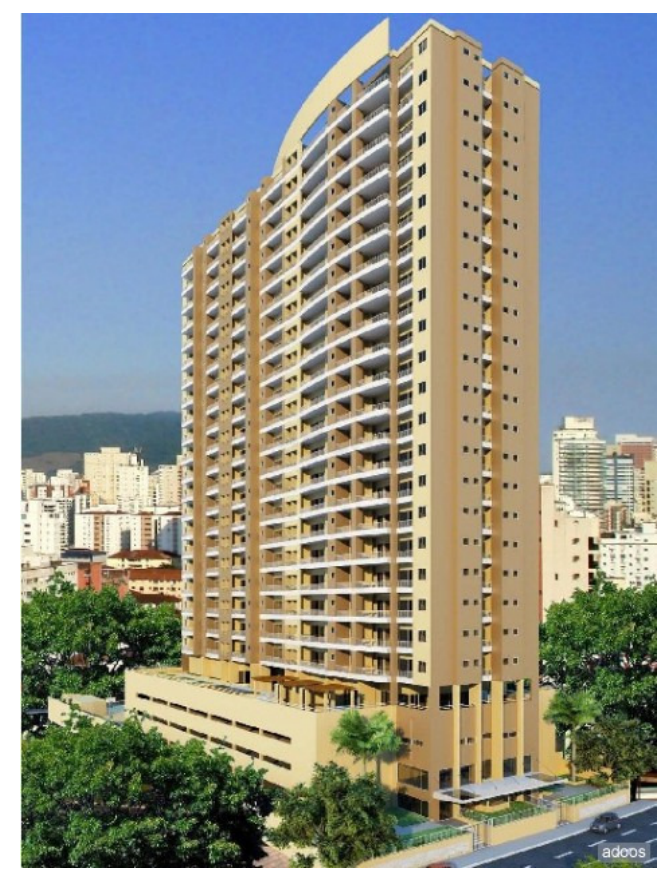

Figura 4.19. Fachada do Bella Vita Eco Club

Fonte: bellavitasantos.com.br

1. Filtro ecológico para toda água usada no condomínio.

2. Captação de água de chuva para uso em irrigação e limpeza.

3. Elevadores inteligentes (econômicos).

4. Torneiras com temporizador.

5. Sensores de presença para iluminação das áreas comuns.

6. Espaço ECO - pomar, horta, herbário.

7. Coleta seletiva de lixo e óleo.

8. Medidores de água individuais nos apartamentos. 
Tabela 4.2. Comparação entre os requisitos do processo AQUA e os itens de sustentabilidade dos empreendimentos (em anexo) 
Considerações sobre a análise dos itens de sustentabilidade dos empreendimentos, em comparação com os requisitos do processo AQUA.

Gráfico 4.2. Atendimento às categorias do processo AQUA pelos empreendimentos.

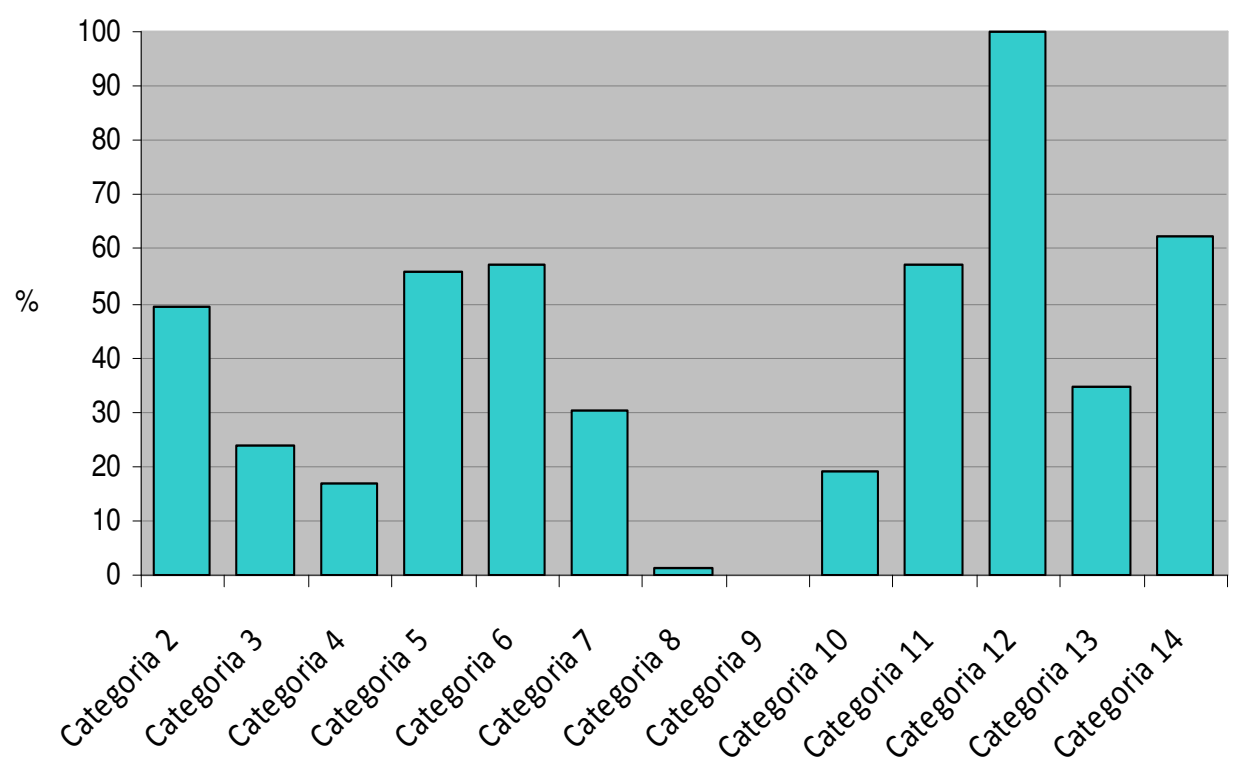

1. Os itens que dizem respeito às normas técnicas deram significativa contribuição na soma dos itens atendidos, o que significa que a maioria os itens atendidos pelas empresas já são, atualmente, obrigatórios por meio de normas e legislações. 0 atendimento desses itens não faz com que um edifício seja considerado sustentável.

2. As categorias 8 (Conforto Higrotérmico) e 9 (Conforto Acústico) foram as categorias menos atendidas. Essas categorias estão diretamente relacionadas ao projeto de arquitetura, o que pressupõe o não planejamento dos aspectos que garantem conforto interno para o morador, no que diz respeito à temperatura, umidade do ar, incidência solar e conforto acústico, por meio de soluções arquitetônicas.

3. A única categoria atendida por completo, a Categoria 12 (Qualidade Sanitária dos Ambientes), diz respeito ao azulejamento de áreas molhadas, obrigatório pelo Código Sanitário do Estado de São Paulo.

4. Para a aquisição da certificação em nível BOM não são exigidas ações de sustentabilidade relacionadas ao entorno do empreendimento (Categoria 1). Se esta 
categoria fosse considerada na análise, poucos requisitos seriam atendidos pelos empreendimentos analisados.

\section{Gráfico 4.3. Atendimento aos requisitos do processo AQUA por} empreendimento.

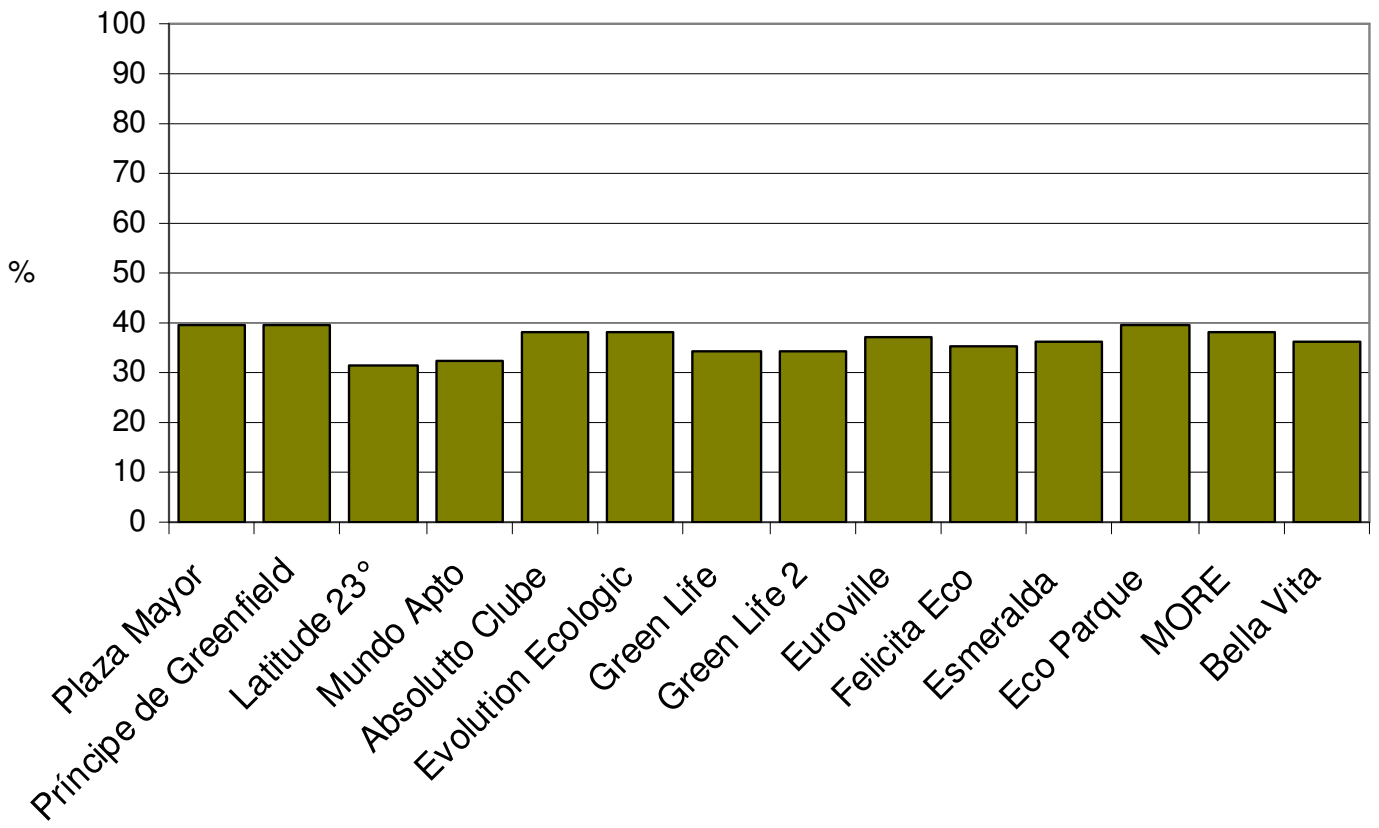

4. Todos os empreendimentos atenderam a uma porcentagem próxima de itens, em torno de $40 \%$. Isto porque as ações de sustentabilidade são as mesmas para todos os empreendimentos, salvo poucas exceções. Em qualquer parte do país, um edifício considerado sustentável pelo mercado imobiliário possui itens como: coleta seletiva de lixo, captação de água da chuva, aquecimento da água com energia solar, iluminação com sensores de presença e outros equipamentos que contribuem para a economia de recursos.

5. De acordo com a análise, nenhum empreendimento atendeu a mais de $40 \%$ dos requisitos do processo AQUA para a certificação em nível BOM, o nível de certificação menos exigente do processo. Deste modo, podemos concluir que nenhum dos empreendimentos analisados poderia ser considerado sustentável para os padrões nacionais. 
Durante toda a pesquisa, através de consultas bibliográficas, experiências adquiridas no mercado, troca de informações com profissionais da área e consultas a websites sobre o assunto abordado neste trabalho, fomos formando um conhecimento sobre as práticas do mercado imobiliário residencial, ao mesmo tempo em que se formava um julgamento sobre o comportamento das empresas do setor. Esse conhecimento proporcionou um esclarecimento do posicionamento das empresas em momentos de decisões, durante o ciclo de vida dos edifícios, o que nos permitiu reforçar o fato de que o mercado imobiliário ainda não age com o propósito de diminuir os impactos da atividade de construção. É importante esclarecer que a não existência de sustentabilidade no mercado não significa que não haja consciência ambiental em alguns casos. O mercado é abrangente e dentro dele existe uma parcela de profissionais que age com seriedade e competência, procurando desenvolver projetos de qualidade e buscando alternativas para minimizar os impactos ambientais das construções. Há, porém, uma grande maioria de empresas que, na tentativa de aproveitar o bom momento econômico e a crescente demanda por produtos ecológicos, usa a causa ambiental de maneira incorreta, para aumentar sua lucratividade.

A seguir, são apresentadas cinco evidências da não existência da sustentabilidade no mercado imobiliário.

\section{Primeiro sinal: A escolha do terreno / idealização}

O primeiro sinal da não existência da sustentabilidade no mercado imobiliário ocorre na escolha do terreno. Para a compra de terrenos, as empresas tomam como base, principalmente,

a) o valor do metro quadrado na região;

b) o coeficiente de aproveitamento e a taxa de ocupação do terreno, permitidos na área;

c) o estoque de outorga disponível na região; 
d) a valorização que pode ocorrer com a presença de pontos de referência próximos ao empreendimento;

e) a adequação da região para a classe social para a qual o empreendimento se destina.

Para uma escolha ambientalmente sensata do terreno, deveriam ser levados em consideração, também, aspectos como:

a) a facilidade de acesso por meio de transporte público;

b) a não destruição de áreas verdes/naturais;

c) a possibilidade de construção com a mínima movimentação de terra;

d) a adequação formal e funcional do empreendimento ao entorno;

e) os impactos que o empreendimento irá causar no trânsito de automóveis da região;

f) as mudanças climáticas locais que o empreendimento poderá causar (ilhas de calor).

\section{Segundo sinal: 0 projeto de arquitetura / concepção}

O segundo sinal da não existência de sustentabilidade acontece no momento da elaboração do projeto de arquitetura. Para isso, muitas vezes a empresa construtora possui um projeto modelo que é enviado a um escritório de arquitetura, para que este faça uma adequação ao terreno, de acordo com a legislação local. Com freqüência, essa adequação é feita visando o uso máximo da área permitida, sem que o entorno imediato seja analisado. Iluminação e ventilação seguem a área mínima permitida pelo Código Sanitário Estadual. Na tentativa de economizar nesta etapa do processo, algumas empresas procuram fazer uso de projetos "carimbo", projetos que podem - desde que atendidos os limites da legislação - ser construídos em terrenos diversos, em locais diferentes da cidade, do estado ou até mesmo do país. Isso torna o projeto de arquitetura um item a mais no processo construtivo, e não uma etapa importante, na qual a tomada de decisões tem influência sobre todo o ciclo de vida do edifício. O desenho das fachadas geralmente segue a tendência de mercado que possivelmente agradará ao gosto do consumidor. 
O projeto de arquitetura é a peça chave da sustentabilidade. É impossível alcançar eficiência ambiental sem que a arquitetura seja pensada para isso. Para a elaboração mais consciente do projeto de arquitetura, as características ambientais e sociais do entorno devem ser levadas em consideração. Com isso, a etapa de escolha do terreno estaria atrelada à etapa de projeto, de modo que a implantação do futuro edifício pudesse ser feita de forma integrada com a vizinhança, valorizando o espaço urbano onde está inserido.

Outro fator imprescindível para o desempenho do edifício é o conforto ambiental de seus ocupantes. Não é possível garantir ventilação, iluminação e conforto acústico adequados, quando não são levados em conta aspectos físicos locais, tais como: deslocamento solar, incidência de ventos e ambiente urbano externo. A escolha dos materiais de construção e do sistema construtivo também influencia no nível de conforto interno, além de ser decisiva para a fase de operação, quando ocorrem as manutenções no edifício.

\section{Terceiro sinal: A construção do edifício / implantação}

No Brasil, o canteiro de obras é um dos maiores causadores de impactos ambientais de todo o processo construtivo. Cerca de 50\% do total de resíduos sólidos urbanos são gerados nos canteiros de obra. A gestão do canteiro ainda se mostra atrasada no país. Ainda assim, essa etapa da obra é pouco abordada quando o tema da sustentabilidade na construção é discutido. Isso acontece por dois motivos principais: o primeiro é que para aplicar ações de sustentabilidade no canteiro de obras seriam necessários profissionais especializados no assunto, já que a abordagem sairia do conhecimento superficial do tema ambiental. Para isso, as empresas teriam que fazer contratações e arcar com os gastos da mudança na forma de executar suas atividades. O segundo motivo é de natureza mercadológica. Os consumidores raramente têm acesso ao canteiro de obras, portanto, qualquer atitude diferenciada e responsável por parte da empresa, nessa fase, não será visualizada pelo comprador. Isso torna a discussão sobre o canteiro de obras pouco atrativa, do ponto de vista comercial. 
Os fatores que fazem do canteiro de obras um elemento de grande impacto ambiental são:
a) Geração de grande quantidade de resíduos e entulho;
b) Geração de ruídos, vibrações e explosões;
c) Geração de material particulado e poeira;
d) Desperdício de materiais;
e) Circulação de veículos de grande porte e ocupação de via pública;
f) Supressão de vegetação;
g) Contaminação do solo, ar e água;
e) Mão-de-obra desqualificada.

Para uma gestão ambientalmente consciente do canteiro, devem ser consideradas as particularidades de cada obra e deve ser feito um planejamento antecipado, apontando os impactos mais significativos e possíveis formas de evitá-los.

Para isso, o Projeto do Canteiro deve ser minuciosamente elaborado, considerando os seguintes aspectos:

1. Garantia da salubridade e organização nas instalações provisórias;

2. Facilitação da circulação de operários e materiais;

3. Adequação das instalações à duração da obra;

4. Delimitação dos setores (armação, carpintaria, argamassa, estocagem, etc);

5. Facilitação do recebimento e estocagem do material;

6. Redução das perdas de material, por desperdício ou desaparecimento;

7. Locação adequada para descarte de materiais;

8. Isolamento dos arredores;

9. Garantia de segurança dos operários / uso de equipamentos de proteção;

10. Treinamento e conscientização dos operários.

\section{Quarto sinal: O uso do edifício / operação}


O grande problema da fase de uso do edifício consiste na falta de informação e conhecimento dos seus ocupantes. Para que os itens ou diferenciais sustentáveis adotados pelos empreendimentos sejam eficientes, é necessário que seus usuários tenham conhecimento de como utilizá-los. A consciência ambiental deve estar incorporada à rotina da sociedade, de modo que suas atitudes sejam tomadas buscando alcançar a sustentabilidade.

A existência, por exemplo, de coleta seletiva de lixo pelo condomínio não garante que os moradores farão a separação correta do lixo para coleta. Grande parte da população brasileira não sabe, ainda, separar o lixo reciclável do não reciclável. $A$ adoção de torneiras com temporizador, descargas com menor vazão e lâmpadas econômicas, não significam que os consumos de água e energia serão menores.

Para que todos os itens de sustentabilidade implantados nos edifícios sejam utilizados corretamente, é necessária uma mudança comportamental, que só poderá acontecer com a reeducação da sociedade, como um todo.

Outro importante aspecto da fase de operação do edifício é a sua manutenção. No intuito de enxugar gastos na fase de construção, a seleção de materiais é feita visando à economia nos custos da obra e não a qualidade dos produtos. No decorrer da fase de operação, o desgaste desses materiais é maior e as manutenções são realizadas com mais freqüência.

Segundo o CBCS - Conselho Brasileiro de Construção Sustentável, a escolha correta de materiais e fornecedores para a construção de um edifício eficiente, devem seguir seis passos:

1. Verificação da formalidade da empresa fornecedora, através da consulta do CNPJ (Cadastro Nacional de Pessoa Jurídica) no site da Receita Federal. 
2. Verificação da licença ambiental da unidade fabril, concedida pelo órgão ambiental estadual, através da consulta do número do protocolo da licença ambiental.

3. Respeito às normas técnicas que garantem a qualidade do produto, por meio de consulta ao site do PBQP-H (Programa Brasileiro de Qualidade e Produtividade do Habitat).

4. Consulta do perfil de responsabilidade socioambiental da empresa. A existência de certificados, como o ISO14001 e o OHSAS18001, é importante. Deve-se verificar a existência do Relatório de Responsabilidade Socioambiental e sua coerência com o catálogo de produtos e serviços, procurando responder às perguntas:

1) A política de responsabilidade socioambiental corporativa é claramente expressa e coerente?

2) A prática de sustentabilidade é aplicada a todos os produtos da empresa ou apenas a uma linha específica?

3) A sustentabilidade é parte da visão e missão da empresa? A política é discutida periódica e sistematicamente com os funcionários e parceiros da empresa?

4) A empresa está comprometida com a saúde e segurança no trabalho dos operários?

5) A empresa reconhece eventuais produtos tóxicos presentes nos produtos e processo e discute alternativas para eliminar o seu uso?

6) O fornecedor possui uma política de gestão dos resíduos decorrentes da montagem e resíduos decorrentes do pós-uso? (Não vale para todos, especialmente para aqueles que fornecem matérias-primas e não produtos acabados.)

7) A empresa apóia organizações que promovem a construção sustentável no Brasil?

8) A empresa aplica o conceito de Análise do Ciclo de Vida para avaliar e aperfeiçoar seus produtos? Esta prática é ainda de difícil implementação no mercado brasileiro, 
devido à falta de um inventário nacional do impacto do ciclo de vida dos principais insumos industriais.

5. Identificação da existência de verniz verde (greenwash). É importante julgar a ecoeficiência global da empresa e não apenas do produto de interesse.

6. Verificação da durabilidade do produto. O Governo Federal, órgãos ligados ao setor de construção e empresas de materiais de construção estão elaborando ferramentas para a implantação da Análise do Ciclo de Vida e a criação da Declaração Ambiental do produto.

\section{Quinto sinal: A demolição do edifício}

A reutilização de edifícios não é comum no Brasil. Por força da herança cultural e por conveniência econômica, os edifícios que chegam ao final de sua vida útil têm como fim a demolição. Com a expansão do mercado imobiliário nos últimos anos e o esgotamento de áreas disponíveis para a construção de novos empreendimentos, tem sido comum a compra de pequenos grupos de casas para demolição e implantação de edifícios verticais ou condomínios residenciais. A demolição de edifícios antigos também tem ocorrido com freqüência, para a sua substituição por edifícios novos.

Essa atividade de demolição, além de contribuir para a perda de uma herança cultural, é causadora de danos ambientais, tais como:

- emissão de gases poluentes;

- geração de entulho;

- geração de materiais particulados e poeira;

- geração de ruídos, vibrações e explosões;

- contaminação do solo, ar e água;

- Circulação de veículos de grande porte e ocupação de via pública.

A reutilização de edifícios é comum nos países europeus e começa a ganhar espaço em outras partes do mundo, em função da causa ambiental. A palavra Retrofit 
é a junção da palavra francesa "retro" (passado) com o termo em inglês "fit" (novo, rejuvenescido). A palavra é usada para definir edifícios recuperados para novo uso, após muitos anos de vida. No Brasil, este conceito é, ainda, novo e não faz parte da rotina do mercado imobiliário. 


\subsection{A ocorrência do greenwash no mercado imobiliário}

As ações de sustentabilidade adotadas pelas empresas do setor de construção geralmente se limitam aos aspectos técnicos, como o uso de aparelhos redutores de vazão para economia de água e sensores de presença para economia de energia na iluminação de áreas comuns. Raramente se aplicam soluções que envolvem aspectos mais importantes, tais como: o uso de energias renováveis, ações para minimizar a poluição do ar, da água, sonora e visual, a diminuição da movimentação de terra, ações que colaborem para evitar alagamentos e o aumento do trânsito, entre outras. Embora haja o interesse de tornar a atividade de construção menos impactante, o interesse econômico no setor ainda é maior. Além disso, a falta de profissionais qualificados no mercado impede que haja progressos e mudanças na maneira de construir, assim como a falta de conhecimento do que vem a ser "sustentabilidade", não só por parte das empresas, mas também, dos consumidores. Isso torna mais difícil o esclarecimento do tema e pode causar uma distorção das informações divulgadas à sociedade, fazendo com que o consumidor adquira um bem que ele pensa ser sustentável, quando está adquirindo um bem igual a todos os outros.

A ocorrência deste tipo de situação é comum atualmente e pode ser chamada de greenwash, ou verniz verde.

Greenwash é um termo que foi incluído oficialmente no dicionário inglês em 1999, porém, seu uso é anterior a esta data. Surgiu em meados da década de 1980 e é usado para definir, segundo ambientalistas e organizações internacionais, a prática de induzir os consumidores ao erro em assuntos relacionados às práticas ambientais de uma empresa ou de benefícios ambientais de um produto ou serviço. O termo é utilizado para descrever organizações que querem aparentar adotar práticas benéficas ao meio ambiente, quando na verdade não o fazem. (CSILLAG, 2008).

De maneira mais formal, o Oxford English Dictionary descreve o Greenwash da seguinte maneira: 
"Desinformação disseminada por uma organização ou empresa, de modo a apresentar uma imagem pública ambientalmente responsável, mas percebida como sendo infundada ou deliberadamente enganosa".

Para esclarecer ainda mais o termo, o Greenwash Guide, documento elaborado pela organização inglesa Futerra Sustainability Communications, o define como "anúncio enganoso ao público, salientando credenciais ambientais de uma pessoa, empresa ou produto, quando estes são improcedentes ou irrelevantes".

No mercado imobiliário, a urgência em atender a um consumidor que começa a se atentar para as causas ambientais, fez com que as empresas reformulassem seus discursos e sua publicidade, usando o verde como estratégia de vendas (SANTANA, 2009), embora o processo construtivo não tenha mudado, e em muitos casos, a consciência das empresas também não. Em função disso, o greenwash tem ocorrido com freqüência em inúmeras propagandas de empreendimentos, que se classificam como sustentáveis, mas se limitam a colocar nos edifícios itens que ajudam a diminuir o desperdício de água e luz, ou que apenas fazem a separação de lixo reciclável, ou, ainda, que possuam outros diferenciais que não evitam que o edifício cause um grande impacto ambiental e social à cidade.

Segundo o Greenwash Guide, os dez sinais da ocorrência do greenwash são:

\section{Linguagem descontraída}

Palavras ou termos sem significado claro para o consumidor (ex.: ecofriendly).

\section{Produtos verdes $x$ empresas sujas}

Empresas que fabricam produtos ecológicos, mas poluem o ambiente durante a fabricação.

\section{Imagem sugestiva}

Imagens que indicam uma injustificável minimização do impacto ambiental (ex.: flores saindo do carburador de um carro). 


\section{Créditos irrelevantes}

Ênfase em um único aspecto positivo irrelevante, quando todo o restante do processo colabora para a degradação do ambiente.

\section{A melhor empresa}

Declarar que a empresa ou o produto em questão é melhor do que os outros, sem embasamento em informações formais.

\section{Créditos injustificáveis}

Declarar que um produto é ecológico, quando seu uso é questionável (ex.: cigarros e herbicidas).

\section{Jargões científicos}

Usar termos ou informações somente entendidos pelos cientistas.

\section{Falsa certificação}

Usar etiquetas ou textos dando a entender que o produto tem aprovação de uma terceira pessoa (órgão ou autoridade governamental).

\section{Falta de provas}

Declarar que o produto é ecológico, sem que se possa provar facilmente, ou que não tenha comprovação científica ou certificação adequada.

\section{Mentira}

Fabricar dados ou selos falsos.

Em geral, os conceitos de sustentabilidade adotados pelas empresas do setor de construção abrangem o aspecto ambiental, com a implantação de itens que contribuem para a diminuição do consumo de energia e água. Outros itens, como seleção e reciclagem de lixo, criação de telhados verdes e plantação de árvores também são consideradas "fatores de sustentabilidade" para as empresas 
construtoras. A adoção desses itens demanda um investimento mínimo por parte das empresas, porém, o retorno financeiro é significativo, já que o uso do marketing sustentável faz com que os empreendimentos se destaquem em função do apelo ambiental. Algumas construtoras e incorporadoras afirmam que seus imóveis podem ter valorização de até $20 \%$ por adotarem atitudes ecológicas (SINDUSCON, 2008).

Seguem, abaixo, exemplos da ocorrência de greenwash no mercado imobiliário brasileiro. A identificação de grenwash está citada nas próprias imagens, na cor vermelha.

Figura 4.20. Ocorrência de greenwash - website da empresa EsoEsfera

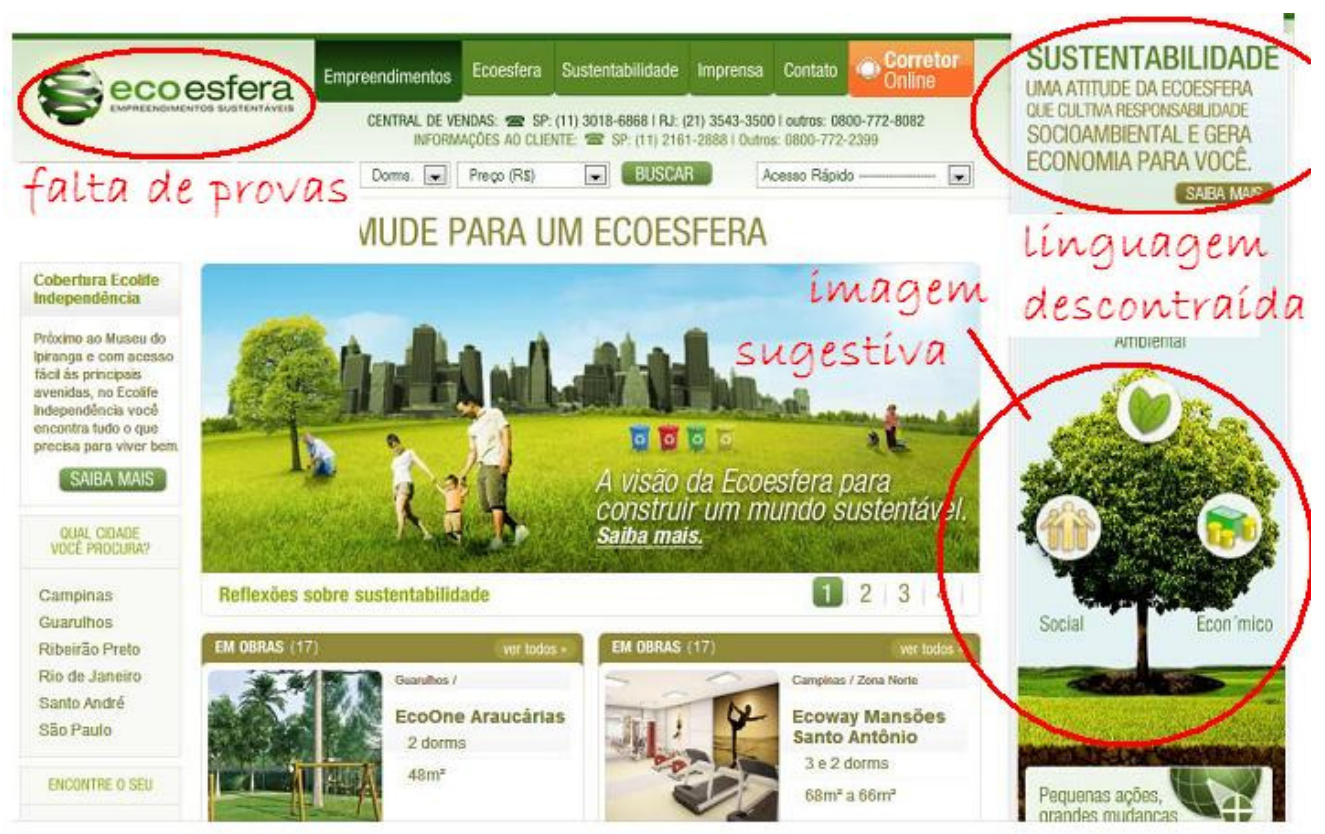


Figura 4.21. Ocorrência de greenwash - website da empresa EcoEsfera
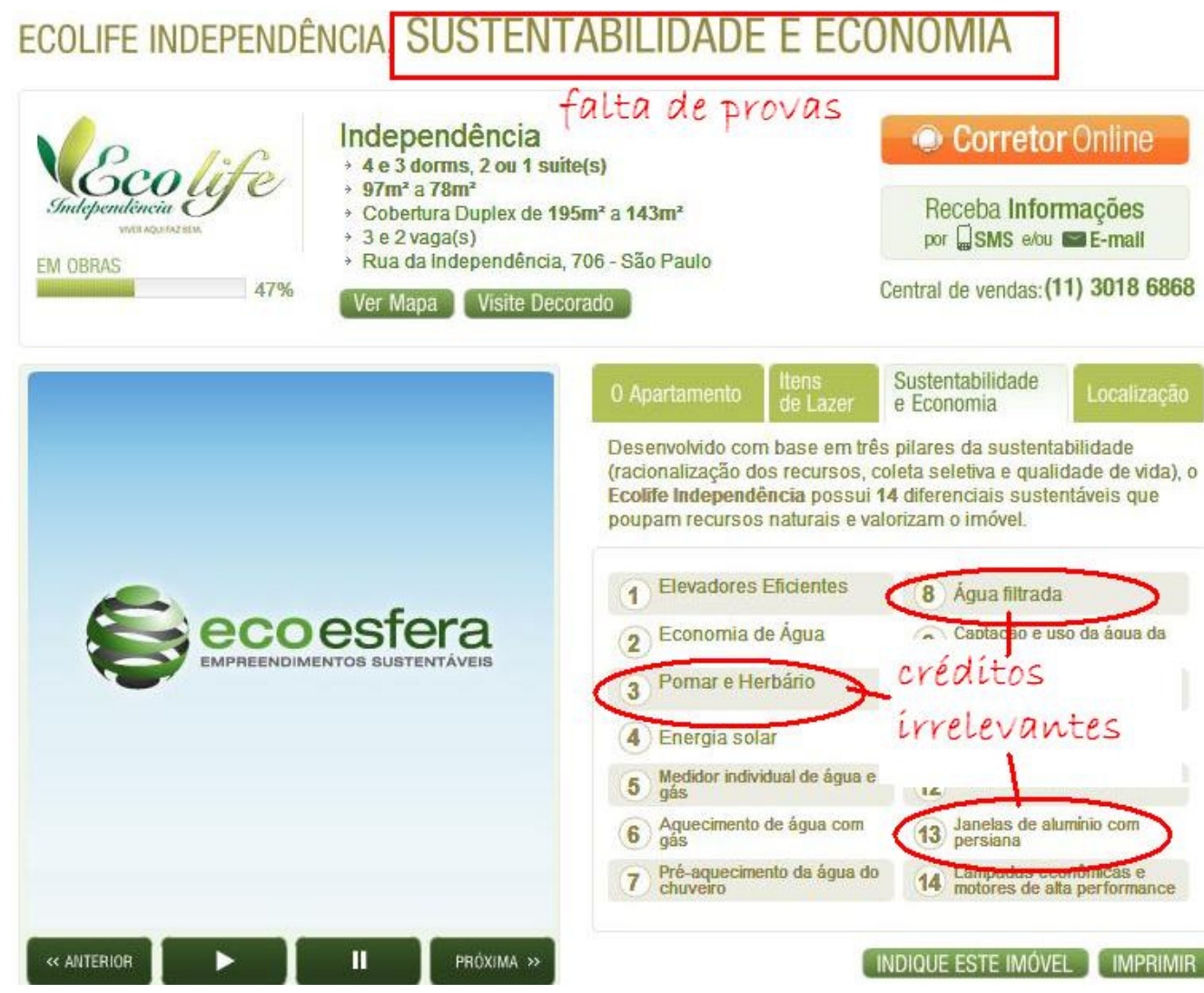

Figura 4.22. Ocorrência de greenwash - website do empreendimento Ecolife Independência

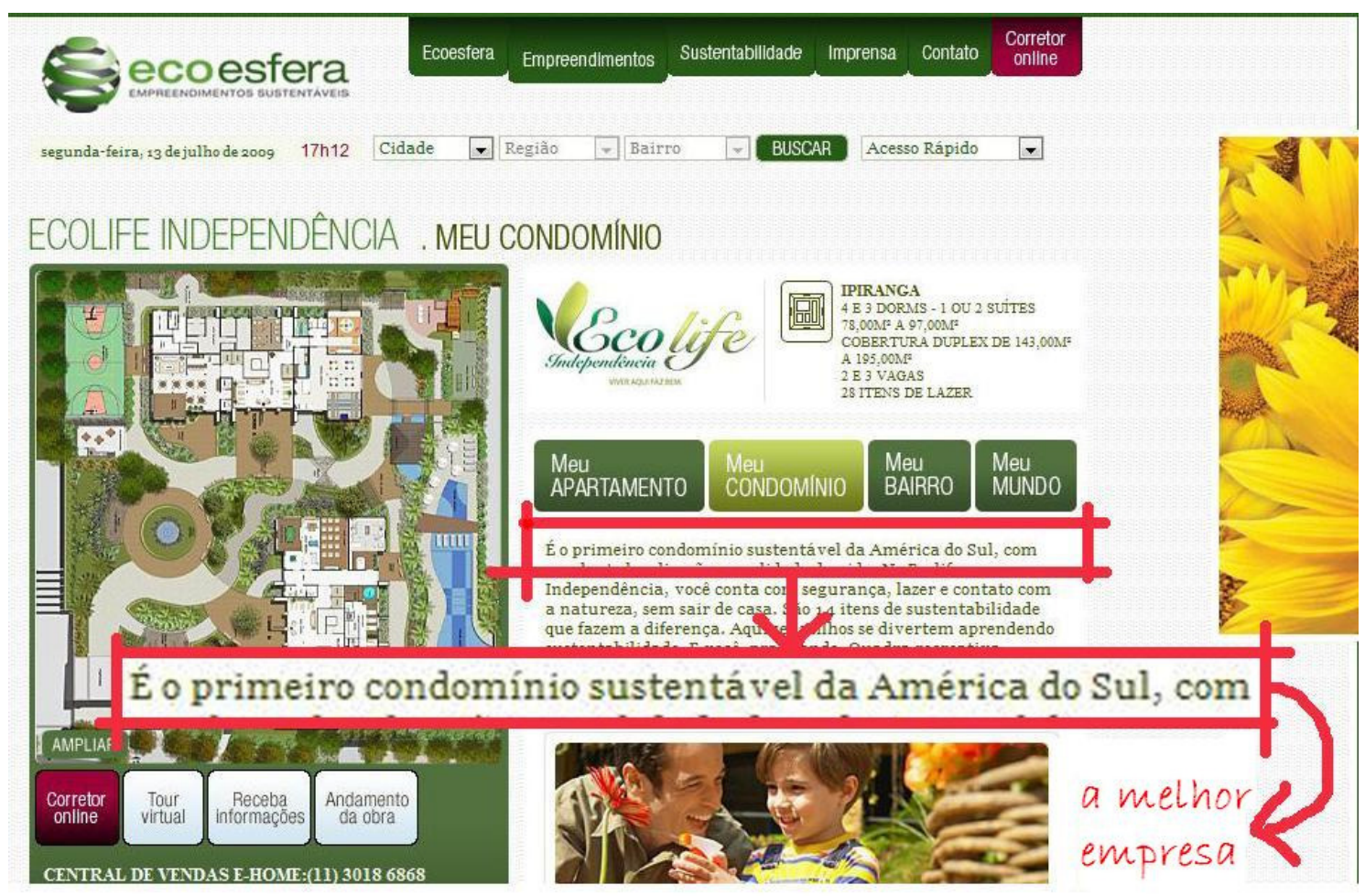


Figura 4.23. Ocorrência de greenwash - website da empresa Euroamérica

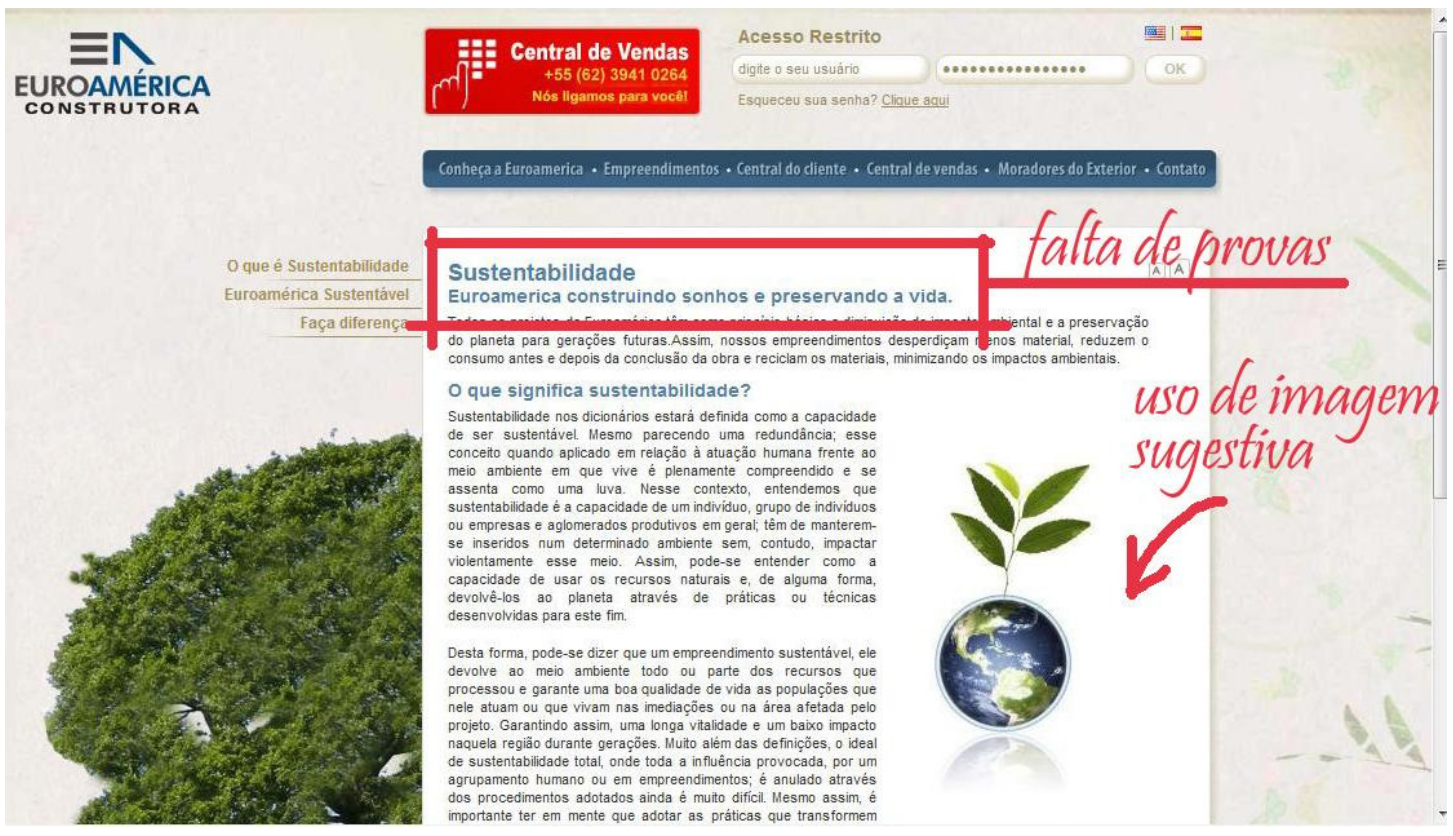

Figura 4.24. Ocorrência de greenwash - website do empreendimento Euroville

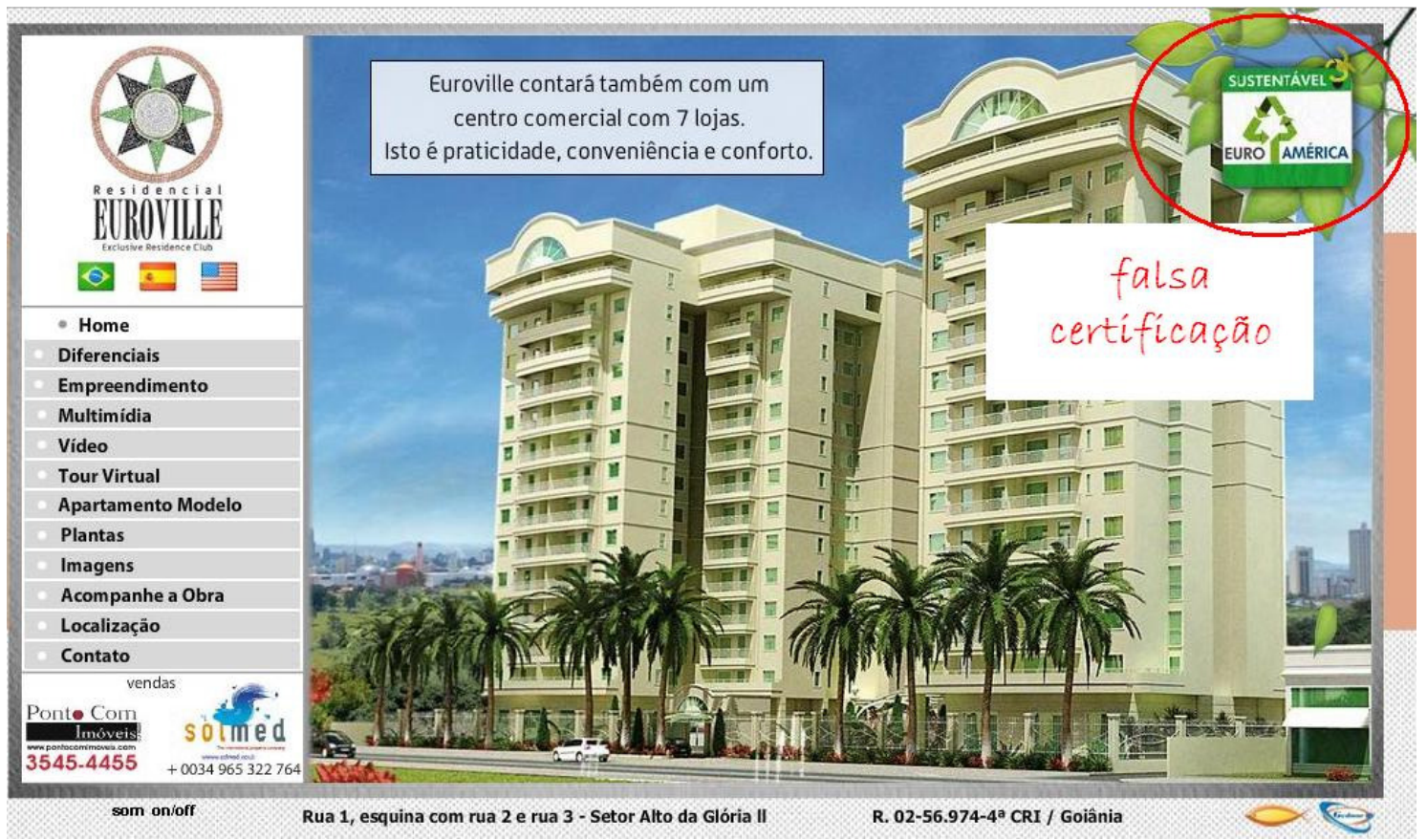


Figura 4.25. Ocorrência de greenwash - website do empreendimento Absolutto

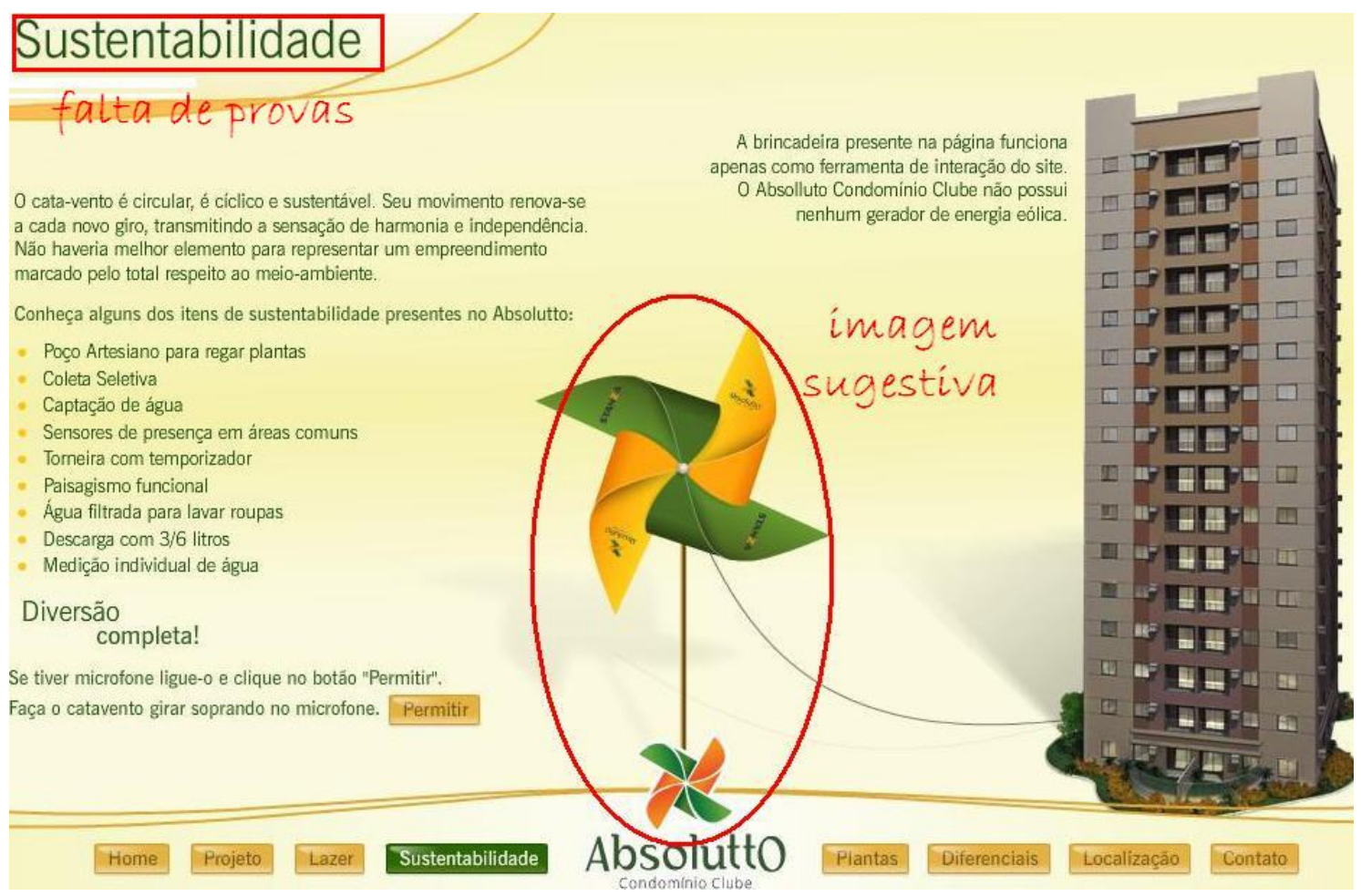

Figura 4.26. Ocorrência de greenwash - website da empresa MRV

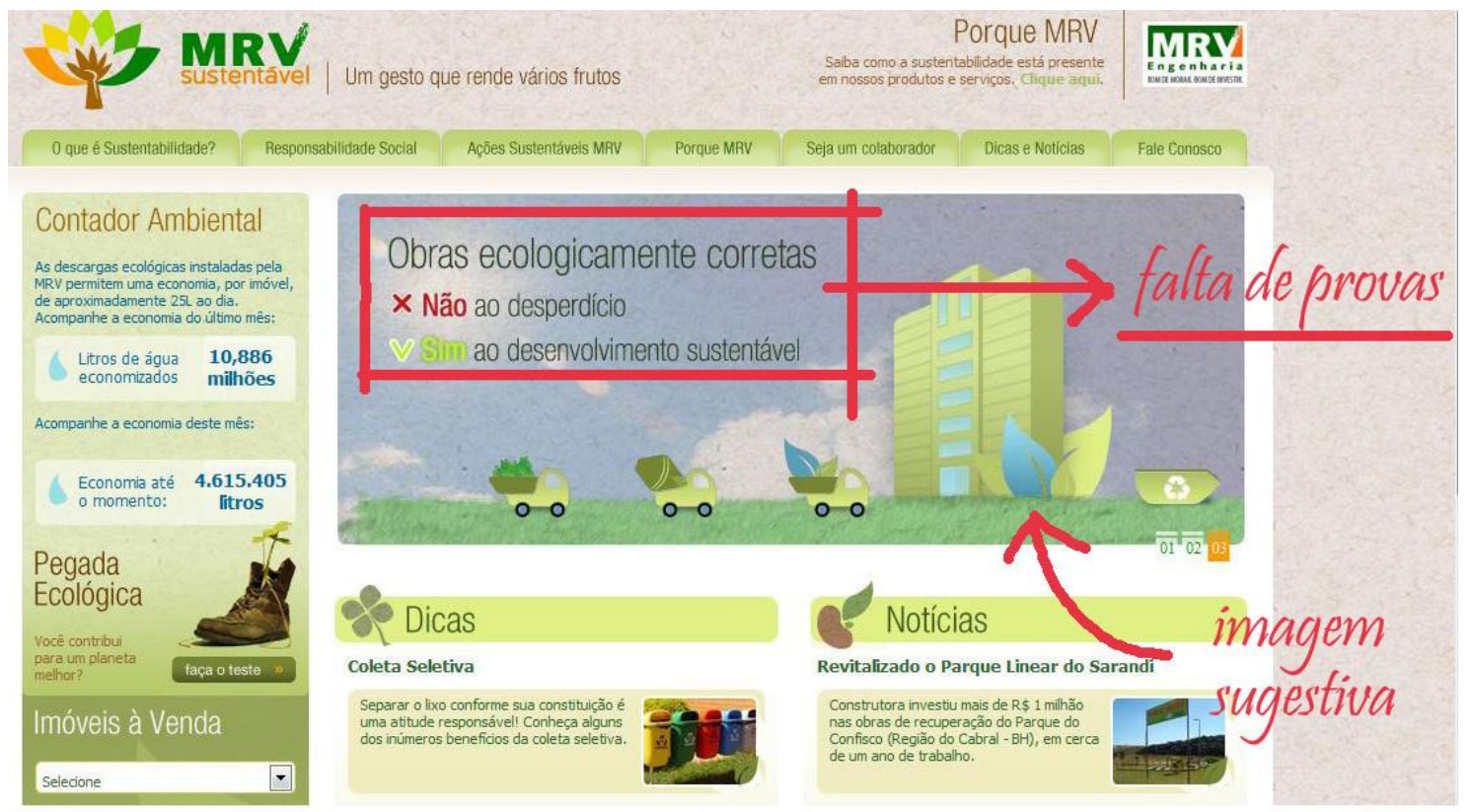


5. CONSIDERAÇÕES FINAIS 
Para que o mercado imobiliário possa dar sua contribuição para a diminuição dos impactos da construção ao meio ambiente, é necessário que haja uma mudança no processo de construir. Embora haja um esforço para que as construções incorporem ações que ajudem a preservar o meio ambiente, quando se leva em consideração o tripé do desenvolvimento sustentável, no qual devem ser abrangidos os aspectos ambientais, sociais e econômicos, o aspecto econômico ainda é o principal objetivo a ser alcançado nas tomadas de decisão.

Nos últimos anos tem havido um desenvolvimento significativo da atividade de construção, com um aumento da demanda por moradia e, ao mesmo tempo, com o surgimento de novas técnicas e novos equipamentos, frutos da evolução tecnológica que começa a ser incorporada pelo setor, após décadas de estagnação e atraso. Esse desenvolvimento tem sido caracterizado pela expansão, pelo crescimento da atividade e pelo aumento do volume de construções, fatores que trouxeram otimismo para os agentes do mercado e para a população, já que esse crescimento pode proporcionar a compra de um imóvel para aqueles que procuram a casa própria.

No entanto, o crescimento da atividade de construção não tem sido acompanhado pelo aumento da qualidade das construções. É um crescimento horizontal, no sentido de abrangência, não um crescimento vertical, no sentido de melhoria. O mercado cresceu em quantidade, mas não em qualidade. 0 desenvolvimento da atividade de construção não veio acompanhado de um progresso no mercado de habitação. Existe uma idéia consolidada na sociedade, de que o mercado imobiliário está construindo mais e melhor para todas as classes sociais. Isto não ocorre. O mercado de habitações para a classe baixa tem crescido significativamente, mas a maior parcela do déficit habitacional está nas classes mais baixas da pirâmide social, não atendidas por ele. Atitudes ambientalmente corretas estão sendo incorporadas pelas empresas de construção, mas os modos de produção continuam agressivos para as cidades. 
A adoção incorreta do conceito de sustentabilidade colabora para um desserviço à causa ambiental, pois confunde os cidadãos e cria a impressão de que todos estão fazendo sua parte para preservar o planeta, quando nenhuma das partes está realmente colaborando para que haja menos degradação ambiental.

Deve haver mais comprometimento dos profissionais e agentes ligados à atividade de construção, principalmente com relação ao projeto de arquitetura, elemento fundamental para o alcance da sustentabilidade e que tem sido colocado em condição secundária no processo de produção dos edifícios. Na produção imobiliária das décadas de 1950, 1960 e 1970 a participação dos arquitetos no processo de projeto proporcionou ao mercado, além do desenvolvimento tecnológico, uma qualidade nunca alcançada em outros períodos. Houve, nessa época, um grande progresso na atividade de construção e na arquitetura brasileira.

O desenvolvimento atual da construção não tem contribuído para um progresso ambiental, para um progresso social, e também não tem contribuído para um progresso econômico, pois as formas de lucratividade seguem a um modelo de concentração, com grandes empresas mantidas pelo capital externo e pelo apoio do governo, dominando a maior parte do mercado. O mercado imobiliário não tem sustentação própria, do ponto de vista econômico.

O otimismo presenciado durante a última década nos leva a acreditar no surgimento de um novo pensamento, mais consciente e mais comprometido com o planeta e com a sociedade. Esse novo pensamento deve ser acompanhado de práticas que demonstrem com mais seriedade o desejo de tornar o espaço urbano mais agradável para vida da sociedade, ou continuaremos vivendo um Mito do Progresso (DUPAS, 2006), e não um progresso, de fato. 
6. REFERÊNCIAS BIBLIOGRÁFICAS 
ÂNGULO, Sérgio C.; ZORDAN, Sérgio E.; JOHN, Vanderley M. Desenvolvimento sustentável e reciclagem de residuos na construção civil. São Paulo, 2001.

BRE - BUILDING RESEARCH ESTABLISHMENT. BREEAM Multi Residential 2006. Reino Unido, 2006.

CÂMARA DA INDÚSTRIA DA CONSTRUÇÃO. Guia de Sustentabilidade na Construção. Belo Horizonte: FIEMG, 2008.

CARDOSO, Francisco F.; ARAÚJO, Viviane M. Levantamento do Estado da Arte: Canteiro de Obras (Documento 2.6). São Paulo: Habitação Mais Sustentável/FINEP, 2007.

CORBELLA, Oscar; YANNAS, Simos. Em busca de uma Arquitetura Sustentável para os trópicos. Rio de Janeiro: Revan, 2003.

CNUMAD - Conferência das Nações Unidas sobre o Meio Ambiente e Desenvolvimento. Carta da Terra. Brasília; Senado Federal / SSET, 1992.

CNUMAD - Conferência das Nações Unidas sobre o Meio Ambiente e Desenvolvimento. Agenda 21. Brasília; Senado Federal / SSET, 1996.

CSILLAG, Diana. Análise das práticas de Sustentabilidade em projetos de construção latino americanos. Dissertação de mestrado: Escola Politécnica da Universidade de São Paulo: São Paulo, 2007.

CSILLAG, Diana; JOHN, Vanderley M. Análise das práticas das construções sustentáveis na América Latina. Boletim técnico (ISSN 0103-9830): Escola Politécnica da Universidade de São Paulo: São Paulo, 2008.

CHOGUILL, Charles L. Cidades sustentáveis e política urbana: considerações sobre a política urbana nacional no Brasil. Cadernos de Pós-Graduação em Arquitetura e Urbanismo, v. 3, n 1: Mackenzie: São Paulo, 2003.

DEGANI, Clarice M.; CARDOSO, Francisco F. A Sustentabilidade ao longo do ciclo de vida de edificios: a importancia da etapa de projeto arquitetônico. NUTAU 2002: São Paulo, 2002. 
D'OtTAVIANO, Maria C. L. Condomínios Fechados na Região Metropolitana de São Paulo: fim do modelo centro rico versus periferia pobre? XV Encontro de Estudos Populacionais, ABEP: Caxambú-MG, 2006.

DUPAS, Gilberto. O mito do progresso; ou progresso como ideologia. São Paulo: UNESP, 2006.

EDWARDS, Brian; HYETT, Paul. Guia Básica de la Sostenibilidad. Barcelona: Gustavo Gili, 2001.

EREC - European Renewable Energy Council. [R]evolução Energética: Perspectivas para uma energia sustentável. Greenpeace, 2008.

FABRICIO, Marcio M. Projeto simultâneo na construção de edifícios. Tese de doutorado: Escola Politécnica da Universidade de São Paulo: São Paulo, 2002.

FABRICIO, Marcio M.; MELHADO, Silvio B. Desafios para integração do processo de projeto na construção de edifícios. São Paulo, 2000.

FITCH RATINGS. Emerging Market Homebuilders: Property Developers in Brazil, China and Russia. Analistas: Michael Wu, Tony Stringer, Ewan Macaulay, Raymond Hill, José R. Romero. Daniel R. Kastholm. Nova Yorque, 2008.

FLAVIN, Christopher. Planeta Rico, Planeta Pobre. Estado do Mundo 2001. Salvador: UMA Ed., 2000.

FRANCO, Maria de A. R. Planejamento Ambiental para a Cidade Sustentável. São Paulo: Annablume, 2001.

FROTA, Anésia B. Geometria da Insolação. São Paulo: Geros, 2004.

FUTERRA SUSTAINABILITY COMMUNICATIONS. The Greenwash Guide. Reino Unido, 2008.

GIRARDET, Herbert. Cities, People, Planet. Chichester, Inglaterra: John Wiley, 2008.

GOULART, Solange; LAMBERTS, Roberto; FIRMINO, Samanta. Dados Climáticos de 14 Cidades Brasileiras. Florianópolis: Núcleo de Pesquisa em Construção UFSC, 2o edição, 1998. 
GONÇALVES, Joana Carla Soares. A Sustentabilidade do Edifício Alto. Tese de doutorado: Faculdade de Arquitetura da Universidade de São Paulo. São Paulo, 2003.

- O Impacto de Edifícios Altos em Centros Urbanos - Discutindo a polêmica da verticalidade e suas implicações. Revista Sinopses, no 32, FAU/USP. São Paulo, 1999.

- Pensando a Cidade Sustentável - Londres e o Bairro Soho. Cadernos Técnicos AUT, no 6, Universidade de São Paulo. São Paulo: FUPAM, 1999.

GONÇALVES, Joana C. S.; DUARTE, Denise H. S. Arquitetura Sustentável: uma integração entre ambiente, projeto e tecnologia em experiências de pesquisa, prática e ensino. Ambiente Construído, v.6, $\mathrm{n}^{\circ}$ 4: ANTAC: Porto Alegre, 2006.

GUILHERME, Marcia Lucia. Sustentabilidade sob a ótica global e local. São Paulo: Annablume; Fapesp, 2007.

HOBSBAWN, Erik J. Tempos Interessantes - Uma vida no século XX. São Paulo: Companhia das Letras, 2002.

Era dos Extremos - O breve século XX 1914 - 1991. São Paulo: Companhia das Letras, 1994.

- Nações e Nacionalismo desde 1780 - Programa, mito e realidade. Rio de Janeiro: Paz e Terra, 1990.

O Novo Século. Entrevista a Antonio Polito. São Paulo: Companhia das Letras, 1999.

HOLANDA, Sérgio B. Raízes do Brasil. São Paulo: Companhia das Letras, 1995.

HQE Haute Qualité Environnementale. La définition explicite de La qualité environnementale (DEQE). Référentiels Complèmentaires HQE. Paris, Association HQE. Disponível em: www.assohqe.org/documents referentiels. Acesso em: janeiro/2010.

IEEP - Intelligent Energy Europe Programme. Consume Green: Energy Efficient Products. EACl, 2008. 
The beauty of efficiency: Energy

efficient homes and buildings. $\mathrm{EACl}, 2008$.

. Eletricity from renewable energy

sources. EACl, 2006.

IPCC-WGI - Working Group I of the Intergovernmental Panel of Climate Change.

Climate Change 2007: The Phisycal Science Basis. Paris, França: UNEP, 2007.

JOHN, Vanderley M.; OLIVEIRA, Daniel P.; LIMA, José A. R. Levantamento do Estado da Arte: Seleção de Materiais (Documento 2.4). São Paulo: Habitação Mais Sustentável/ FINEP, 2007.

JOHN, Vanderley M.; SILVA, Vanessa G.; AGOPYAN, Vahan. Agenda 21: uma proposta de discussão para o construbusiness brasileiro. ANTAC: Canela, 2001.

JOHN, V. M. Reciclagem de Resíduos na Construção Civil: contribuição à metodologia de pesquisa e desenvolvimento. Tese (Livre-docência). Escola Politécnica da Universidade de São Paulo. Departamento de Engenharia de Construção Civil. São Paulo, 2000.

Reciclagem de entulho para a produção de materiais de construção - Projeto entulho bom. Organizado por Alex Pires Carneiro, Irineu Antônio Schadach de Brum e José Clodoaldo da Silva Cassa. Salvador: EDUFBA; Caixa Econômica Federal, 2001. 312p. Capítulo 1 Aproveitamento de resíduos sólidos como materiais de construção.

KATS, Gregory H. Green Buildings Costs and Financial Benefits. Massachusetts Technology Collaborative: Estados Unidos, 2003.

KOWALTOWSKI, Doris C. C. K.; LABASKI, Lucila C.; PINA, Silvia A. M. G.; SILVA, Vanessa G.; MOREIRA, Daniel C.; RUSCHEL, Regina C.; BERTOLI, Stelamaris R.; FÁVERO, Edison; FRANCISCO, Lauro L. F. Análise de parâmetros de implantação de conjuntos habitacionais de interesse social: ênfase nos aspectos de sustentabilidade ambiental e da qualidade de vida. Habitare, vol. 07. Campinas, 2004. 
LABEEE - LABORATÓRIO DE EFICIÊNCIA ENERGÉTICA EM EDIFICAÇÕES. Regulamentação para Etiquetagem Voluntária do Nível de Eficiência de Edifícios Comerciais, de Serviços e Públicos. UFSC/PROCEL EDIFICA, 2008.

LAMBERTS, Roberto; DUTRA, Luciano; PEREIRA, Fernando O.R. Eficiência Energética na Arquitetura. São Paulo: PróLivros, 2004.

LAPP, Thais F. S. O. A diversidade das formas capitalistas de produção habitacional na estruturação da metrópole paulista. Dissertação de mestrado: Faculdade de Arquitetura e Urbanismo da Universidade de São Paulo: São Paulo, 2006.

LEME, Maria Cristina da S. O Impacto da Globalização em São Paulo e a Precarização das Condições de Vida. Santiago do Chile: Revista Eure, no 87, 2003.

MALTHUS, Thomas Robert. An Essay on the Principle of Population. New York: Oxford University Press, 1993.

MARICATO, Ermínia. Habitação e Cidade. São Paulo: Atual, 1998.

MASCARÓ, Juan L. O custo das decisões arquitetônicas. Porto Alegre: JLM, 2004.

MEADOWS, D.H. Limits to Growth. New York: Universe Books, 2004.

MINDLIN, Henrique E. Arquitetura Moderna no Brasil. Rio de Janeiro: Aeroplano Editora, 1999.

MINISTÉRIO DO MEIO AMBIENTE. Cidades Sustentáveis - Subsídios à elaboração da AGENDA 21 Brasileira. IBAMA. Brasília, 2000.

MONTANER, Josep M. A modernidade Superada: arquitetura, arte e pensamento do século XX. Barcelona: Gustavo Gili, 2001.

MÜHLFART, Roberta C. K. Impacto e Consumo Energético Embutido em Materiais de Construção - Técnicas Construtivas. Dissertação de mestrado apresentada ao IEE/USP - Instituto de Eletrotécnica e Energia da Universidade de São Paulo, Programa de Pós Graduação em Energia, 1998. 
Arquitetura de Baixo Impacto Humano e Ambiental. Tese de doutorado apresentada à Faculdade de Arquitetura e Urbanismo da USP. São Paulo: 2003.

- A Sustentabilidade $e$ a Arquitetura. REVISTA ARQUITETURA E URBANISMO. São Paulo: Pini, junho de 2006.

O ESTADO DE SÃO PAULO. Grandes Reportagens - Megacidades. Periódico anual. São Paulo, agosto de 2008.

OLIVEIRA, Roberto; BERTOGLIO, Daiane; MEZZOMO, Melissa. O Plano Diretor como Instrumento de Promoção de Sustentabilidade Ambiental. COBRAC 2008: Florianópolis, 2008.

ORNSTEIN, Sheila W. Qualidade e Segurança das Habitações. Cadernos Técnicos da Arquitetura, no 6, Universidade de São Paulo. São Paulo: FUPAM, 1999.

ORNSTEIN, Sheila W.: ABIKO, Alex. K. Inserção Urbana e Avaliação Pós Ocupação (APO) da Habitação de Interesse Social. São Paulo: Coletânea Habitare/FINEP, 2002.

PEREIRA, Miguel A. Arquitetura: cultura, formação, prática e política profissional. São Paulo: Pini, 2005.

RIBEIRO, Darcy. O Povo Brasileiro: a formação e o sentido do Brasil. São Paulo: Companhia das Letras, 2006.

ROCHA, Janaíde C.; CHERIAF, Malik. Aproveitamento de resíduos na construção. Coletânea Habitare, 2003.

ROGERS, Richard; GUMUCHDJIAN, Philip. Cidades para um pequeno planeta. Trad. A. R. Di Marco. Barcelona: Gustavo Gili, 2005.

ROLNIK, Raquel; SOMEKH, Nadia. Governar as metrópoles - dilemas da recentralização. São Paulo: São Paulo Perspectiva, 2000.

Cidades e Políticas Urbanas no Brasil - Velhas questões, novos desafios. Org. Henrique Rattner. São Paulo: EDUSP, 2000.

SADER, Emir. A Vingança da História. São Paulo: Boitempo, 2003. 
SAMPAIO, Maria Ruth A.; PEREIRA, Paulo César X. Habitação em São Paulo. Estudos Avançados, 17. São Paulo, 2003.

SANTOS, Daniel C. Os sistemas prediais e a promoção da sustentabilidade ambiental. ANTAC: Curitiba, 2002.

SANTOS, Milton. A Urbanização Brasileira. São Paulo: EDUSP, 2005.

. Metamorfoses do Espaço Habitado. São Paulo: EDUSP, 2008.

. Manual da Geografia Urbana. São Paulo: 3a edição, EDUSP, 2008.

Por uma Outra Globalização. Rio de Janeiro: 14ạ edição, 2007.

Território e Sociedade - Entrevista com Milton Santos. São Paulo: Perseu Abramo, 2000.

SCUSSEL, Maria C. B.; SATTLER, Miguel Aloysio. Qualidade do Espaço Residencial e Sustentabilidade: (Re)Discutindo conceitos e (Des)Construindo Padrões. Revista Brasileira de Estudos Urbanos e Regionais, v. 6, $\mathrm{n}^{\circ} 2$. ANPUR, 2005.

SERRA, Geraldo G. Pesquisa em Arquitetura e Urbanismo: guia prático para o trabalho de pesquisadores em pós-graduação. São Paulo: Edusp, 2006.

SILVA, Vanessa G. Metodologias de avaliação de desempenho ambiental de edifícios: estado atual e discussão metodológica. São Paulo: Habitação Mais Sustentável/FINEP, 2007.

SILVA, Vanessa G.; SILVA, Maristela G.; AGOPYAN, Vahan. Avaliação de edifícios no Brasil: da avaliação ambiental para a avaliação de sustentabilidade. Ambiente Construído, v. 3, n³: ANTAC: Porto Alegre, 2006.

SINDUSCON-SP - Sindicato da Indústria da Construção Civil do Estado de São Paulo. Gestão Ambiental de Resíduos da Construção Civil. São Paulo: SindusconSP, 2005. 
SINDUSCON-SP - Sindicato da Indústria da Construção Civil do Estado de São Paulo. Coordenador Oswaldo Poffo Ferreira. Madeira: Uso sustentável na construção civil. São Paulo, SindusconSP, 2003.

SMOLKA, M. O. O capital incorporador e seus movimentos de valorização. Cadernos IPPUR/UFRJ: Rio de Janeiro, 1987.

SOLANO, Nelson; GONÇALVES, Joana C. S. Iluminação e Arquitetura. São Paulo: Geros, 2001.

SOUZA, Ubiraci E. L.; DEANA, Davidson F. Levantamento do Estado da Arte: Consumo de Materiais (Documento 2.5). São Paulo: Habitação Mais Sustentável/FINEP, 2007.

TRIANA, Maria A.; LAMBERTS, Roberto. Metodologia de avaliação ambiental brasileira para o setor residencial: eficiência energética. ENCAC 2007: Ouro Preto, 2007.

UNEP - United Nations Environment Programme. Buildings and Climate Changes - Status, Challenges and Opportunities. Asia Pro Eco Programme, 2007.

USGBC - Green Building Council. Sustainable Building Technical Manual: Green Building Design, Constructions and Operations. United States: Public Technology Inc.,1996.

. LEED for Homes Rating System. Estados

Unidos, 2008.

VARGAS, Heliana C. Intervenções em Centros Urbanos: objetivos, estratégias e resultados. Barueri, SP: Manole, 2006.

VIEIRA, Liszt; BREDARIOL, Celso. Cidadania e política ambiental. Rio de Janeiro: Record, 1998.

WCED - World Commission on Environment and Development. Our Commom Future - The Brundtland Report. Oxford: Oxford University Press, 1987.

WHITAKER, João S. F. O mito da cidade global - o papel da ideologia na produção do espaço urbano. Petrópolis, RJ: Vozes, 2007.

YEANG, Ken. Ecodesign. Londres: John Wiley, 2006. 
YEANG, Ken. Reinventing the Skyscraper. Londres: Wiley-Academy, 2002. . The Green Skyscraper - The Basis for Designing Sustainable Intensive Buildings. New York: Prestel, 1999.

YIN, Robert K. Estudo de caso - Planejamento e Métodos. Porto Alegre: Bookman, 2005.

\section{Consulta eletrônica}

emplasa.sp.gov.br

onu-brasil.org.br

sempla.prefeitura.sp.gov.br

sindusconsp.org.br

un.org

unep.org

ecoesfera.com.br

mrvsustentavel.com.br

even.com.br

teitelbaum.com.br

atmosfera_ubatuba.blogspot.com

setin.com.br/mundoapto

celi.com.br/stanza/absolutto

lopes.com.br/salvador/evolution

idibra.com.br

euroamericaconstrutora.com.br

viaimovel.com.br/felicitaecorasidencial

mazzinigomes.com.br

costavituzzo.com.br

bko.com.br/morealphaville

bellavitasantos.com.br 